University of Rhode Island

DigitalCommons@URI

Open Access Master's Theses

1982

\title{
The United States Self-Determination Policy in Indian Affairs: An Indicator Systems Policy Analysis
}

Joanne Cassulo

University of Rhode Island

Follow this and additional works at: https://digitalcommons.uri.edu/theses

\section{Recommended Citation}

Cassulo, Joanne, "The United States Self-Determination Policy in Indian Affairs: An Indicator Systems Policy Analysis" (1982). Open Access Master's Theses. Paper 641.

https://digitalcommons.uri.edu/theses/641

This Thesis is brought to you for free and open access by DigitalCommons@URI. It has been accepted for inclusion in Open Access Master's Theses by an authorized administrator of DigitalCommons@URI. For more information, please contact digitalcommons-group@uri.edu. 
THE UNITED STATES SELF-DETERMINATION POLICY IN INDIAN AFFAIRS:

AN INDICATOR SYSTEMS POLICY ANALYSIS

BY

JOANNE CASSULO

A THESIS PROJECT SUBMITTED IN PARTIAL FULFILLMENT

OF THE REQUIREMENTS FOR THE DEGREE OF

MASTER OF COMMUNITY PLANNING

AND

AREA DEVELOPNENT

APPROVED:

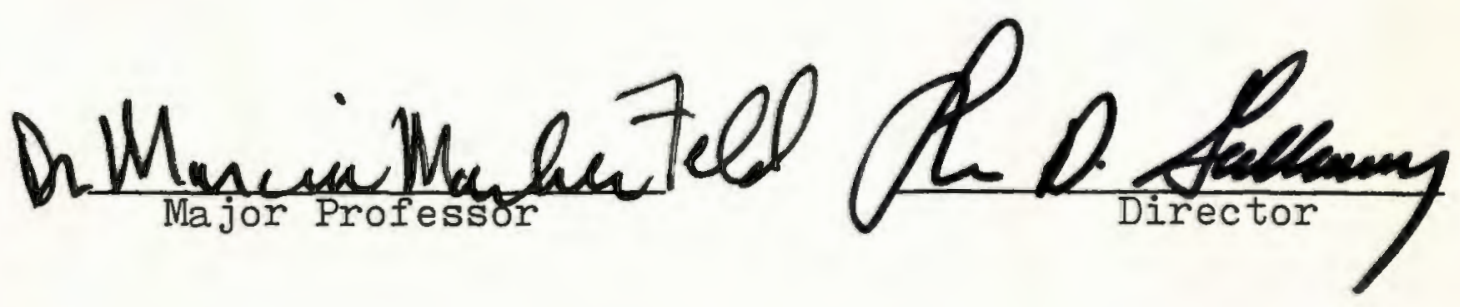

UNIVERSITY OF RHODE ISLAND

1982 


\section{ACKNOWLEDGENENTS}

This project was undertaken with the guidance and assistance of certain key individuals who deserve recognition. I would first like to thank Dr. Marcia Marker Feld for her teaching skills in social indicator analysis which provided the stimulus for pursuing this particular research project. In addition, I appreciate her faith and encouragement in my ability to apply this method to Indian affairs, an area of policy which has always been exceedingly complex and variable throughout the history of the United States.

I would also like to express my gratitude to the several sources of information, the Navajo Division of Education, the Navajo Tribal Council and the Bureau of Indian Affairs, who have offered their assistance during every stage of the research project.

Lastly, I pay tribute to the Navajo Indian tribe whose desire to contribute and improve the quality of life of their people has been responsible for the new direction of Federal policy in the 1970's. 


\section{PREFACE}

The focus of this project is on recent American Indian history and its exemplification of constantly emerging ways of dealing with and adapting to the new legislative thrusts of the United States; namely, the self-determination policy of the $1970^{\prime} \mathrm{s}$.

The approach which is taken in this research project relies on the method of social indicator analysis to establish the organizational framework for the study. Its application to Indian Affairs represents a new trial for policy analysis. The lack of a coherent information system on a group which depends on the Federal government for much of its financial assistance to deal with social problems on reservations has slowed the development of a complex, analytical evaluation of policy decisions in this area.

The research attempts to quantify the social conditions on the country's largest Indian reservation and the effect self-determination has had on improving these conditions. The role of the study group (the Navajo) is not intended to be the main focus of the research. It is more an evaluation of the method of social indicator analysis and its application 
to policy decisions. Questions which are critiqued by this project are:

Does the data base adequately measure social change?

Can indicator analysis be used to formulate policies and evaluate previous decisions?

These questions are intended to raise the issue of using indicators to measure social changes and social conditions. 
ACKNOWLEDGEMENTS $\ldots \ldots \ldots \ldots \ldots \ldots \ldots \ldots$ ii

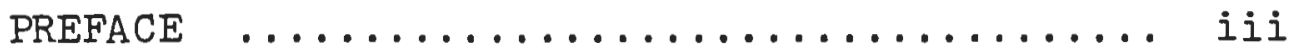

INTRODUCTION $\ldots \ldots \ldots \ldots \ldots \ldots \ldots \ldots \ldots \ldots \ldots$

Chapter

I. FEDERAI INDIAN POLICY ............ 5

Introduction $\ldots \ldots \ldots \ldots \ldots \ldots \ldots \ldots$

History ................... 5

Summary ................... 12

Educational History ............ 14

Summary: Present Education

Delivery System ............ 23

II. SOCIAL INDICATOR MODEL .......... 27

Introduction ................. 27

Theoretical Framework ............ 27

The Model ................. 28

Data Base ................... 43

III. INDICATOR ANALYSIS $\ldots \ldots \ldots \ldots \ldots \ldots \ldots$. 51

Introduction ................ 51

Policy Instrument Indicators ....... 51

Non-Manipulable Indicators ........ 55

Analytic Indicators ............ 62

Output Descriptive Indicators ....... 68

Side Effect Indicators ........... ?I

Findings .................. 74

Critique $\ldots \ldots \ldots \ldots \ldots \ldots \ldots \ldots \ldots, 77$

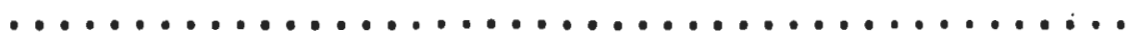

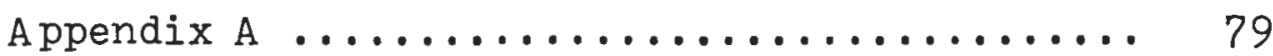

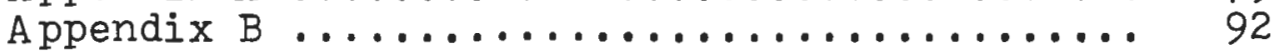

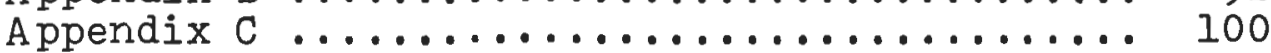

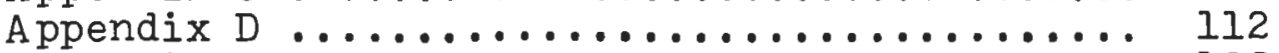

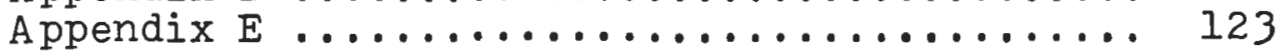

BIBLIOGRAPHY $\ldots \ldots \ldots \ldots \ldots \ldots \ldots \ldots \ldots \ldots \ldots$ 


\section{IIST OF ILLUSTRATIONS}

I. Navajo Reservation $\ldots \ldots \ldots \ldots \ldots \ldots \ldots 2$

2. Boundary Changes of Navajo Iand ........ 7

3. 1980 Location of Schools ............. 24

4. Social Indicator Model ............... 29

\section{LIST OF TABLES}

I. Navajo Catch-Up Requirements:

II. Selected Indicators by Type:

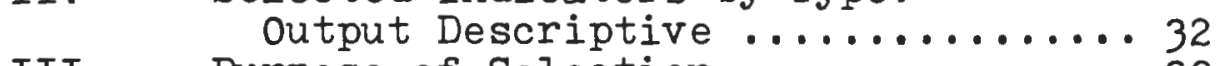

III. Purpose of Selection ............. 33

IV. Selected Indicators by Type:

Analytic Indicators ............. 34

V. Purpose of Selection $\ldots \ldots \ldots \ldots \ldots 35$

VI. Selected Indicators by Type:

Policy Instrument ........... 36

VII. Purpose of Selection ........... 37

VIII. Selected Indicators by Type:

Non-Manipulable ................ 38

IX. Purpose of Selection .............. 39

X. Selected Indicators by Type:

Side Effect ................4 40

XI. Purpose of Selection ............4I

XII. Data Base Characteristics:

Policy Instrument Indicators ..... 45

XIII. Data Base Characteristics: Non-Manipulable Indicators .....4 46

XIV. Data Base Characteristics: Analytic Indicators $\ldots \ldots \ldots \ldots 48$

XV. Data Base Characteristics:

XVI. Data Base Characteristics:

Side Effect Indicators ........ 50 
LIST OF TABLES (cont.)

XVII. Data Compilation:

Policy Instrument Indicators ........ 52

XVIII. Data Compilation:

Non-Manipulable Indicators ........ 56

XIX. Data Compilation:

Analytic Indicators $\ldots \ldots \ldots \ldots \ldots .63$

$\mathrm{XX}$. Data Compilation:

Output Descriptive Indicators ....... 69

XXI. Data Compilation:

Side Effect Indicators 
INTRODUCTION

The objective of this research project is to examine the policy of self-determination in Indian affairs by focusing on the social changes which have occurred in the decade during which this policy became effective with the passage of the Indian Self-Determination Act in 1975. Since this policy and subsequent legislation addresses several comprehensive and complex issues, certain limits have been placed on the research. The American Indian tribe which will be used as the population boundary is the Navajo who reside on the reservation land located in the Four Corners Area of Arizona (see Figure 1). The functional area selected for analysis is education which is a key social process and a primary concern of the Navajo due to their young population (median age in 1980 was 18.8 years).

This paper is organized into three main chapters which review policies in Indian affairs and the application of indicator analysis to the self-determination goal endorsed by Nixon in 1970. Within the first chapter, a background of previous policy and legislative enactments is given in order to provide for a more comprehensive understanding of the role Federal policy statements play in the social processes which interact in Indian culture. In addition, the present status 


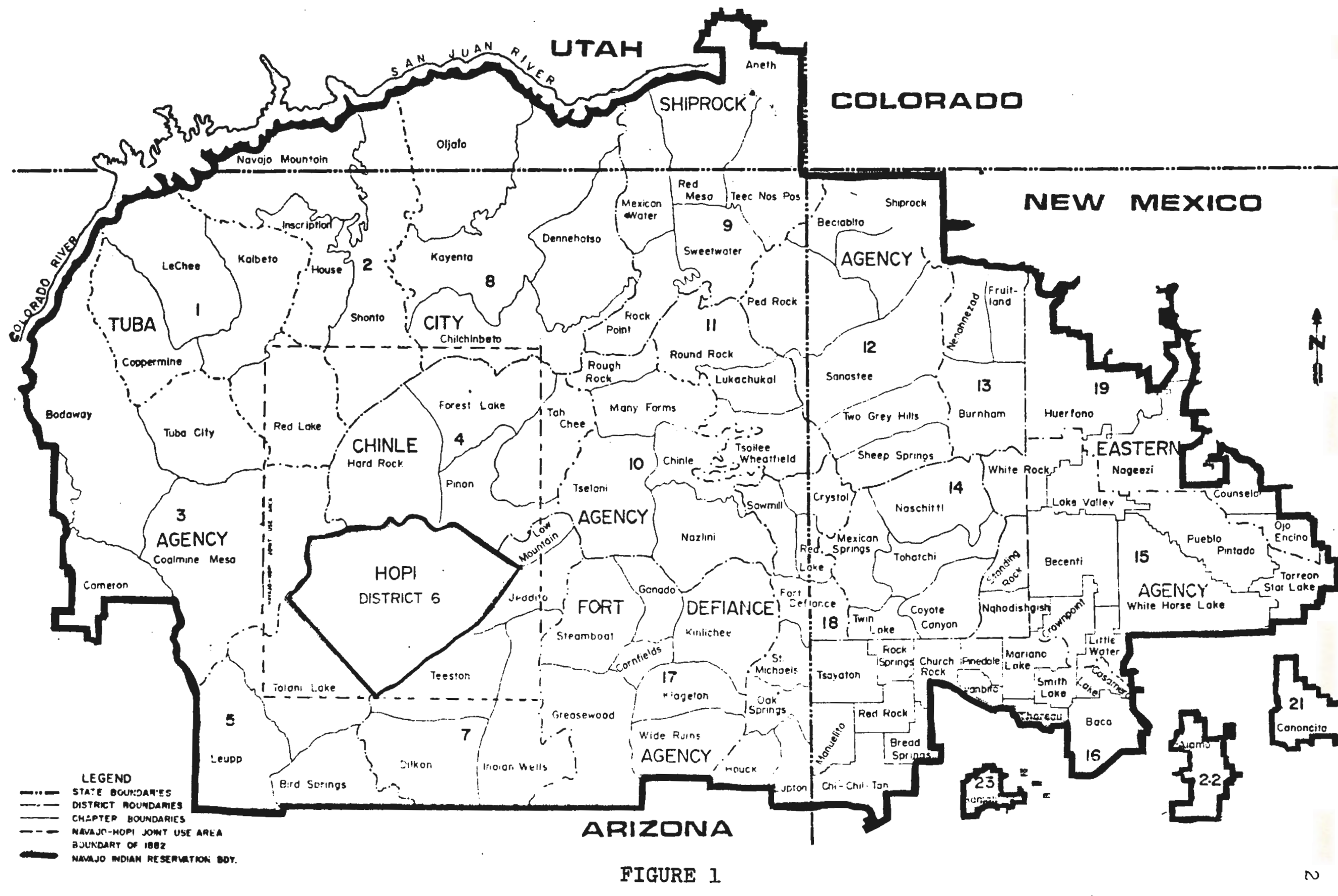


of Indian tribes, legally and politically, and its effect on the educational delivery systems on the Navajo reservation is also outlined in order to give a more detailed background into the social process of education and its role in Indian society. This information provides the necessary conceptual framework for a discussion of the current legislation, the Self-Determination Act, and its implicit goal of improving social conditions on the reservations.

The second chapter on the social indicator model explores the use of a social indicator model which aids the researcher in the selection of relevant variables which measure the effect of self-determination on the education process. The model is designed to integrate each variable selected for analysis into a comprehensive framework in order to facilitate the evaluation of the goal of selfdetermination on education. This new direction in Indian affairs is researched in detail by identifying the relationship between indicators and organizing them into the model for analysis. The outcome of this analysis is a study of the various components of the educational system and their relationship to the overall functional area of education. Implicit in this approach is an attempt to evaluate the effect of this policy statement on improving the quality of life of the Navajo.

The final chapter reviews the data collected and interprets 
the final results of the analysis for its implications in the evaluation of the improvement in the educational achievement through self-determination. A final note is included as a critique of this approach in dealing with policies on complex issues such as Indian affairs. Particular attention is paid to the reliability of the method and an evaluation of conclusions which can be formulated from the final data analysis. 
CHAPTER I

FEDERAL INDIAN POLICY

Introduction

This chapter briefly describes the history of Federal policy since the signing of the 1868 treaty with the Navajo for their present reservation land. Early Navajo history is not recounted here since its relevance to the study is not significant.1 The chapter is divided into two main sections, an overview of major federal action in Indian affairs and a history of the educational directives contained in the major policy statements and legislation.

\section{History}

There has always existed a special relationship between Indian tribes and the United States. The first major agreement between the Navajo and the United States government clearly defined this relationship. The Treaty with the Navajo ${ }^{2}$ set up a separate nation for them in the area where four states join their boundaries (see Figure 1). In this treaty, the Navajo agreed to keep peace with the United States

1. For an excellent history of the Navajo prior to 1868 see John Upton Terrell, The Navajo (New York: Weybright and Talley, 1970).

2. Treaty between the United States of America and the Navajo Tribe of Indians, concluded June 1, 1868, 15 Stat. 667 . 
and remain on the land designated as Federal reservation territory in exchange for their own system of political organization and social and legal control which would interpret tribal laws and apply them to those under its jurisdiction. Generally speaking, the Treaty allowed the States which"hosted" the Navajo reservation (Utah, New Mexico and Arizona) no jurisdiction over Indians within their boundaries. Since the signing of this treaty, the original, restricted boundaries, combined with a growing population, required successive changes in reservation land beginning in 1878 (see Figure 2 for a history of the boundary changes since the original treaty).

The first major policy phase has its roots in the 1830's when the continuing westward pressure of white settlement led to the relocation and restriction of Indian land. The Indian Removal Act of $1830^{3}$ provided that the Federal government could unilaterally trade United States territory west of the Mississippi for any Indian-occupied lands east of the same river. Less than twenty years later, the government reaffirmed its restriction of Indian rights. In a rider to an 1872 Indian appropriation bill, 4 Congress provided that from that time forward, tribes were no longer to be considered as sovereignties with whom the government could negotiate treaties. However, existing treaty rights,

$$
\begin{aligned}
& \text { 3. } 4 \text { stat. } 411 \text { (1830). } \\
& \text { 4. } 16 \text { stat. } 66 \text { (1871). }
\end{aligned}
$$




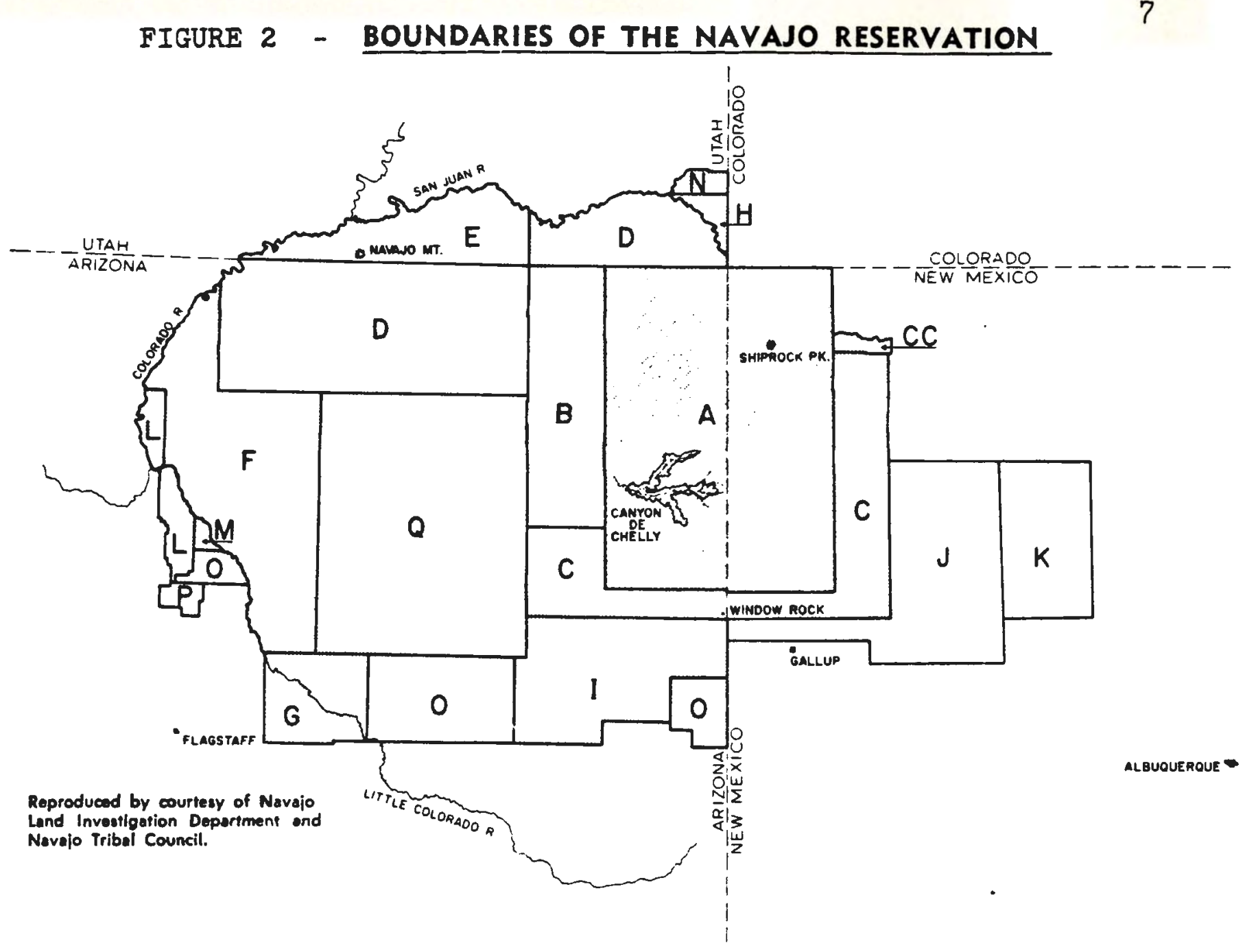

A Original treaty reservation. June 1, H 1868.

B

c

cc

D (two parts)

E

Executive-order addition. October 29, 1 1878.

Executive-order addition. January 6, 1880.

Originally a part of "C"; withdrown from the reservation by execulive order, May 17, 1884; restored by executive order, April 24, 1886.

Executive-order addition. May 17, 1884.

The Paiute Strip. Originally part of "D"; in 1892 restored to the publte domain; in 1908 withdrawn for the use of various Indians; restored to public domain in 1922; in 1929 ogain withdrown from entry; 1933 transferred permanently to the Novajo reservation.

Executive-order addition. Januery 8 , 1900.

Executlve-arder addition. Novamber i4, 1901.
Executive-order addition. March 10, 1905.

Executive-order addition. November 9 , 1907.

Executive-order addition. November 9, 1907; restored to public domain by executive order of January 16, 1911.

K Executive-order addition. November 9, 1907; restored to public domain by executive order of December 30, 1908.

Tusayan Forest addition. Act of May 23. 1930.

M Executive-order addition. May 7, 1917.

N Act of Morch 1, 1933.

O (three parts) Arizona Boundary Act of June 14, 1934.

Tuseyan Forest addition. Act of February 21, 1933. vation created on December 16, 1882. 
like those granted to the Navajo, were not affected. In 1887, Congress continued its erosion of Indian sovereignty by passing the Allotment Act, better known as the Dawes Act ${ }^{5}$, which provided for the division of reservations into individually owned parcels. The tribal land which remained after individual allotment was to be purchased by the Federal government and subsequently opened to white homestead entry. This Dawes Severalty Act of 1887 was designed to destroy the reservation system and tribal solidarity by allotting land to individual Indians.

In 1934, Congress reversed its policy with the passage of the Indian Reorganization Act. ${ }^{6}$ The reservations were now reorganized under tribal ownership and tribal self government was encouraged. The Act allowed tribes to reestablish their governing powers by drafting their own constitutions and setting up their own court systems rather than operating as agencies under the Federal government. By the 1950's, policy direction reversed again with Congress advocating the assimilation of the Indian population into the dominant culture. Related to this termination approach was the passage of Public Law 83-280.7 This Law permitted states to assume jurisdiction over civil and criminal actions by affirmative legislative action. Thus, Congress gave states the power to assume judicial jurisdiction

5. 24 Stat. 388, current version at 25 U.S.C. \$331 (1976). 6. 48 Stat. 984, current version at 25 U.S.C. $\$ 461$ (1976). 7. 67 Stat. 588 , current version at 25 U.S.C. 11162,28 U.S.C. $\mathrm{s} 1360(1976)$. 
over the Indian tribes within their boundaries by amending their state constitutions.

By the mid-1960's, Federal policy moved into the area which is the focus of this study; self-determination in Indian affairs. The primary example of the beginning of this new policy was the passage of the Civil Rights Act of 1968. ${ }^{8}$ The Act devoted two titles to Indian Rights and Jurisdiction over Criminal and Civil Actions (Titles II and IV, respectively). Section 1302 of Title II imposes a "Bill of Rights" requirement on all tribes. Many Indian leaders and tribal members have expressed their dissatisfaction with this section since it enforces "Anglo" concepts of fundamental human rights on traditional Indian customs and cultural traits. The Bill of Rights now required "due process" in the Indian courts as well as a provision for Federal court habeas corpus review of tribal orders (section 1303). In contrast, Title IV ruled that state control of Indian judicial matters could only be assumed by a majority vote of approval of the Indians residing on a reservation within a particular state boundary. This Title was received more favorably than Title II by Indian leaders. Nixon's Message to Congress on Indian Affairs' further supported the concept of self-determination by advocating an increasing role for Indians in administering their own affairs. This policy opened up new opportunities for all Tribes. His policy rejected the earlier statements of

8. 25 U.S.C. $891303-1341$ (1970).

9. See Appendix A for the transcript of Nixon's Message. 
termination of Federal assistance to Indians on three points:

- Federal-Indian relations must continue on the agreement of past treaties where Indians have given up claims to large tracts of landholdings and accepted life on reservations.

- Based on past experiments with termination, economic and social conditions declined sharply after policies became effective.

- Fear of termination has created a greater reliance on the Federal authorities by the Navajo which, in effect, has reinforced the paternalistic programs under governmental control and particularly stagnated the achievement level of Indian tribes. Nixon's policy advocated a greater role for American Indians in their own affairs without fear of termination. This goal of self-determination was enforced as the only approach which would achieve a quality of life for Indians similar to the level of other United States citizens. The discrepancy between statistics on Indians who live on reservations and the overall United States figures was well documented by the 1970 Census of Population. At the time of Nixon's address, Indian leaders were publicizing their demands for equality with these statistics. (See Table I for a summary of some key indicators which were being used by the Navajo to support their demands for self-determination and equal opportunities). Nixon's Message was influenced by 
TA BLE I

NAVAJO CATCH-UP REQUIREMENTS: SOCIAL INDICATORS

Income

per capita personal income

1970 (SA \& BIA)

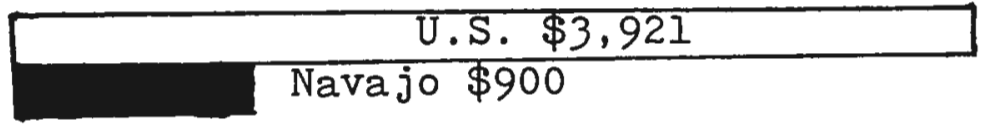

Employment

percent of labor force with jobs, 1970 (MRP \& NCC)

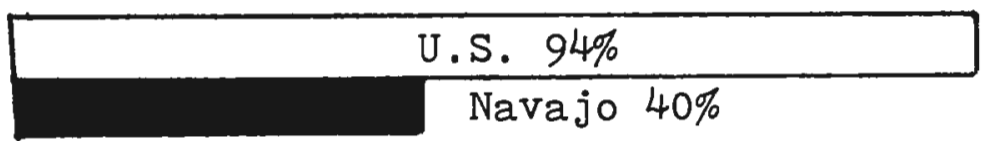

Education

average school years by adults, 1970 (SA \& BIA)

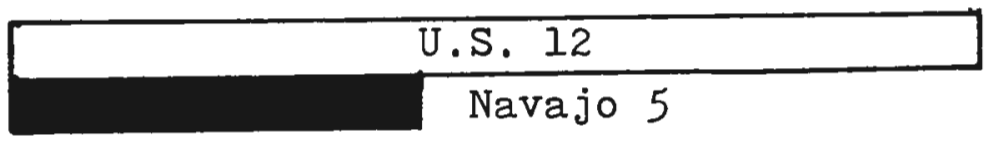

Health

infant survival ratio, 1970 (PHS)

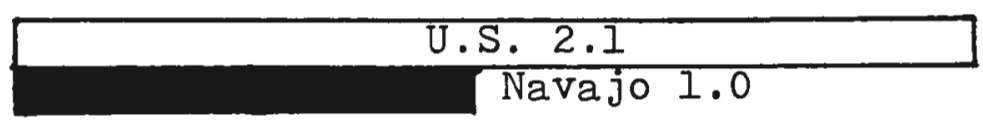

Housing

percent of homes with standard inside plumbing (SA \& PHS

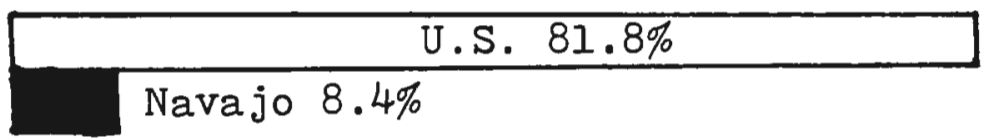

Transportation

miles of surfaced roads per $1,000 \mathrm{sq}$. mi. (SA and BIA)

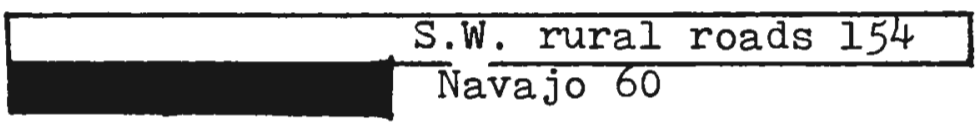

Sources: SA - Statistical Abstract of the United States; BIA Navajo Area office, Bureau of Indian Affairs; MRP - Manpower Report of the President; NCC - Navajo Community College; PHS Navajo Area Office, Public Health Service 
the Indian activities as he intended the goal of self-determination to be implemented by increasing participation of the Navajo in the decision-making process in order to improve social conditions in three main areas: educational achievement, health care and economic development. In addition, an improvement in these areas, according to Nixon's address, required that Indian communities have their own lawyers, doctors, educators . . The key assumption of the concept of selfdetermination is that an increase in self-determination will improve the economic and social conditions which presently exist on the reservations.

The legislation which developed from this policy became law in 1975 (see Appendix B). The Congressional declaration supported Nixon's Message by declaring that the obligation

of the United States is to respond to the strong expression of the Indian people for self-determination by assuring maximum Indian participation in the direction of educational as well as other Federal services to Indian communities so as to render such services more responsive to the needs and desires of those communities. 10

\section{Summary}

The Federal policy reviewed here allows for an interpretation of an Indian tribe as a political body endowed with the power of self-government. The historical evolution of the status of Indians in the United States has placed them in the unique position of both citizens and wards of the country: they comprise sovereign nations which are nevertheless 
subject to certain Federal regulations.

Since the Indian Reorganization Act in 1934, the Navajo government has expanded its representation and broadened its powers. The legislative power today still derives from the tribal council, but that council now consists of 74 delegates instead of six. Every member of the Council must be over 30 and a member of the Navajo Tribe. The delegates serve four year terms, are forbidden to hold other employment that may create conflicts of interest and are subject to removal by a two-thirds vote of the Council or by petition of fifty percent of the voters in their home precinct. The Council meets four times a year, with its agenda set by the Advisory Committee of the Council and the Bureau of Indian Affairs Director (evidence of the continuing Federal supervision of Indian affairs).

In addition, the Tribe has its own court system and an extensive code, covering the structure of government and matters of importance to the Navajo daily life, such as agriculture, ceremonies, commerce and trade, estates, domestic relations, elections and law and order. All of this leads to a picture of a detailed self-government. However, for many important processes, such as Federal excise tax exemptions and access to Federal highway programs, this government is still not recognized by relevant Federal authorities.

In conclusion, this section on key Federal policy decisions was intended to provide the necessary framework 
under which the educational system operates. The purpose of tracing policies from 1868 was to integrate the various changes in Federal directives and to disclose how Indians have adapted to these changes over time. Since the focus of this paper is on the educational perspective in Federal policy, the following section concentrates on the history of that area since the 1868 Treaty as it relates to the major policy decisions outlined in the above section.

\section{Educational History}

Many treaties between the United States and the Indian tribes provided for the establishment of facilities for school gged children. As mentioned previously, the first major treaty with the Navajo Indians was in 1868 and included the provision that "every Navajo child between the ages of six and sixteen must attend and reside at a school teaching an English education."ll Article six, which included this statement, is often cited as the foundation for Federal control of Indian education which still exists on the reservation today.

For discussion purposes, Navajo educational history is divided into four phases:

1. Years of Neglect (1868-1887)

This is the adjustment period of the Navajo to life on

11. Supra note 2 at Article six. 
the reservation under the 1868 Treaty. The Treaty's promise of education and a "competent teacher for every 30 children between the ages of six and sixteen years who can be compelled to attend school"12 remained unfulfilled during this time period. The first school was established at Fort Defiance in 1869 and was abandoned by 1872 due to poor attendance. ${ }^{13}$ All ather attempts at opening both mission and Federal schools met with this problem of poor attendance by the Navajo children. The lack of enforcement of the Treaty provision was the fault of both the Federal government and the Indians. The Navajo did not want to send their children away to boarding schools when they were needed at home as a source of labor and the Federal government did not make any effort to educate the parents on the value of educational development for the young children.

2. Years of Criticism (1887-1933)

This phase is characterized by changes brought to the educational system in response to the failure of the Federal govermment to enforce the educational directive of the 1868 Treaty. In 1887, Congress passed a new law which established "compulsory" education and forced Indian students to attend schools. Even with the change in language which no longer allowed Indian education as an option, school attendance did not improve. In 1888, only 75 out of a school aged population

12. Ibid.

13. According to the Bureau of Indian Affairs' records, attendance ranged from three to thirty-three students during the four years the school was open. 
of approximately 16,000 students were in school. 14 This continuing slow progress in school attendance was also manifested in school development with only nine boarding schools built during this phase.

The failure of the Federal government's educational policy in Indian affairs prompted Interior Secretary Hubert Work to commission a source outside the government to study the problem. In 1928, the Brookings Institute, a nonprofit and nonpolitical organization located in Washington D.C., reported to the Secretary on the Bureau of Indian Affairs' activities. In the area of education, the report criticized the Bureau's educational philosophy of separating Navajo children from the community and suggested the integration of the school curriculum with the realities of reservation life as one method to increase school attendance.

\section{Years of Endeavor (1934 - 1960)}

This phase deals with the changes that occurred as a result of the Commission's report. The first major development was the creation of a day school system to supplement the boarding school system already in existence. The day school was a significant improvement to reservation life since these schools often served as cultural and educational centers for the adult community as well.

There were also key legislative actions taken during this

14. Bureau of Indian Affairs, Statistics Concerning Indian Education, (Washington D.C., 1888). 
period wich achieved the objective of providing Indian children with an equal opportunity to learn.

In 1934, the Johnson-0'Malley Act (JOM) was passed. This Act authorized the Secretary of the Interior to contract with any state school or private agency for the "education, medical attention, agricultural assistance and social welfare, including relief of distress of Indians." 15 While the wording indicates broad coverage, the JOM funds have been mainly used by the Bureau of Indian Affairs to finance the education of Indians in the public school system. According to the Federal regulations, the Bureau of Indian Affairs administers the Johnson-0'Malley program to accommodate unmet financial needs of school districts related to the presence of large blocks of nontaxable Indian owned property in the district and large numbers of Indian children which local funds are inadequate to meet. In effect, the Federal government is paying the States to educate Indian children by substituting Johnson-0'Malley funds for state and local property taxes. These taxes cannot be collected from Tribes such as the Navajo since they live on a reservation which is tax-exempt Federal land.

The Bureau of Indian Affairs regulations governing JOM fund distribution require that each state submit, for the Bureau's approval, a plan outlining fund allocation among its school districts (see Appendix C for a sample plan from the state of Arizona.) These regulations address the problem of special programming and Indian participation in the funding

$$
\text { 15. } 25 \text { U.S.C. \$ } 452 \text { (1970). }
$$


process with the state plan giving preference to special programming over operational funding. The majority of these plans have five main goals in Indian education:

- To increase academic and cultural knowledge of Indian youth through the development of supplementary programs based upon local assessments and goals;

- To increase student self-awareness in educational programs and services available or planned through special interest projects created under the Plan;

- To increase parental participation within the local education agency through the programs created under this Plan and such other services made available in the State Department of Education;

- To reduce the percentum of Indian youth dropouts from public schools through the specialized programs created under the Plan;

- To develop proficiency of Indian youth in the language and communications skills.

other legislation passed which provided Federal financial assistance to compensate public school systems are Public Law $874^{16}$ and Public Law 815.17

Public Law 815 funds were designed to support (in lieu of taxes) rapid facilities expansion or school construction. Public Law 874 impact funds provide general operating

16. 20 U.S.C. $8236-241 .(1950):$

17. 20 U.S.C. 631 et. seq. (1950). 
expenses to school districts in lieu of taxes. In order to insure that JOM funds and 874 monies do not overlap, Congress passed amending legislation ${ }^{18}$ so that Johnson-0'Malley used funds only for special programming for Indian students and 874 was targeted for general operating funds.

All of the legislative enactments in this period were an attempt by the Federal government to provide for quality and quantity educational opportunity for Indians. The success or failure of the legislation and the appropriation of funds is not evaluated here since this section is only intended to be a history of educational policy and legislation in Indian affairs. The summary part of this section evaluates more fully the implementation of the legislation and policy directives of this phase and the following one, Years of Achievement. 4. Years of Achievement (1960-1980)

This last phase is characterized by more intensive activity in the effort to increase educational opportunities for the Navajo.

Continuing legislative improvements include:

- The Elementary and Secondary Education Act which recognized the needs of economically and educationally deprived children. Title 1 provides financial assistance for local school districts to offer supplemental educational services to students whose family income is below the poverty level. This Act allowed many Indian children from poor \$238 (1950). 19. 20 U.S.C. $\$ 8^{241}$ et. seq. 
families to receive additional aid.

- Indian Education Act (Title IV of Education Amendments of 1972). This Act provides Federal Aid directly to local school districts and to tribal educational institutions for "meeting the special educational needs of Indian children and adults and for training teachers to aid in Indian education. "20 This Act makes a specific provision for Indian community participation in the planning, operation and evaluation of Title IV programs. Title IV also encourages improvement in Indian adult education by providing money to assess the extent of adult illiteracy and the lack of high school education in the Indian community and to test the viability of literacy programs and high school equivalency teaching methods in use.

- 1924 Amendments to Johnson-0'Malley Act. These amendments allowed the Bureau of Indian Affairs to streamline the funding process by giving the Navajo Area Office responsibility for handling both the New Mexico and Arizona Johnson-0'Malley contracts. In addition, the Navajo Tribal Council passed a resolution directing the Navajo Tribe to replace the states of Arizona, New Mexico and San Juan County, Utah, as the party contracting with the Bureau of Indian Affairs for all JON funding, programming and monitoring on the reservation. The Navajo Tribal

$$
\text { 20. } 20 \text { U.S.C. \$\$ } 24 \text { et. seg. }
$$


Division of Education now has monitoring responsibilites for the JOM programs in all three states. This Division of Education developed a comprehensive plan for unification of the Bureau of Indian Affairs network with the state public school system. This plan (see Appendix D) does not require the Tribe to operate the reservation schools but allows the Tribe to set uniform standards in areas such as teacher certification and curriculum content. Its powers include negotiation with state educational agencies, the Bureau of Indian Affairs' schools and other agencies affecting Indian education; recommendations and proposals of legislation regarding educational matters and the administration and coordination of funds allocated for educational programs.

- Nixon's Message to Congress has been summarized in the previous section. However, his speech contained several significant directives for the area of educational achievement. He advocated a policy that allowed the Indian community to take over the control and operation of federal programs, including the control of its own Indian schools. This policy became the underlying principle for Dublic Law 90-638, the Indian Self-Determination and Education Assistance Act. This Act allowed Tribes to contract for administration of Bureau of Indian Affairs' schools on the Tribes' reservations. Congress had now elevated Nixon's policy on education to a national goal by declaring that the "United States 
provide for the quantity and quality of educational services and opportunities which will permit Indian children to compete and excel in the life areas of their choice and to achieve the measure of self-determination essential to their social and economic wellbeing." 21 Title II of the Act gives Indian parental groups veto authority over the use of federal funds for the construction of needed public school facilities on or near the reservation.

- Public Law 95-471 22 provides grants to tribally controlled community colleges, allowing many Indian students to attend two year colleges in their own communities. The Bureau of Indian Affairs is currently funding fifteen of these colleges, including the Navajo Community College which is chartered, operated and owned by the Navajo Tribe.

- Education Amendments Act of 1978 (Title XI. Public Law 95-561) 23 made major changes in the administration of Indjan education programs, givirg substantial control of programs to the local Indian community. They established, in the BIA, a new line of authority structure of professional educators not under the Commissioner or area directors and made policy setting and program guidance the responsibility of local school boards, working with local school authorities.
21. Supra note 10 at $\mathbf{5} 450 \mathrm{a}(\mathrm{c})$.
22. 25 U.S.C. \$s1801-1815 (1978).
23. 25 U.S.C. 目82001-2019 (1978). 


\section{Summary: Present Educational Delivery System}

As outlined in this section, the Navajo reservation is served by a multiplicity of school systems: the public schools in Arizona, New Mexico and Utah, the schools administered by the Bureau of Indian Affairs and private schools contracted to the Navajo Tribe. As of 1980, there were 54 Bureau of Indian Affairs' schools ( 42 boarding schools and 12 day schools) and four contract schools (three day and one boarding school). (See Figure 3 for the location of each school by type.) The reservation is also served by over 14 public school districts in the three states. This educational delivery system has been cited as one causal agent in the low educational level of the Navajo population. These three systems have operated independently with little coordination in curriculum choice or standards.

The Bureau of Indian Affairs' school system is federally maintained and serves the Navajo population with a series of day and boarding schools. These schools are traditionally in the rural, isolated areas on the reservation where public school access is limited.

Since Indians: are United States citizens, the public schools a Navajo attends are entitled to receive the Federal aid mentioned in the above section. This funding has been criticized since it often functions as a "carrot" dangled by the United States, through the Bureau of Indian Affairs, 
FIGURE 3

1980 LOCATION OF SCHOOLS

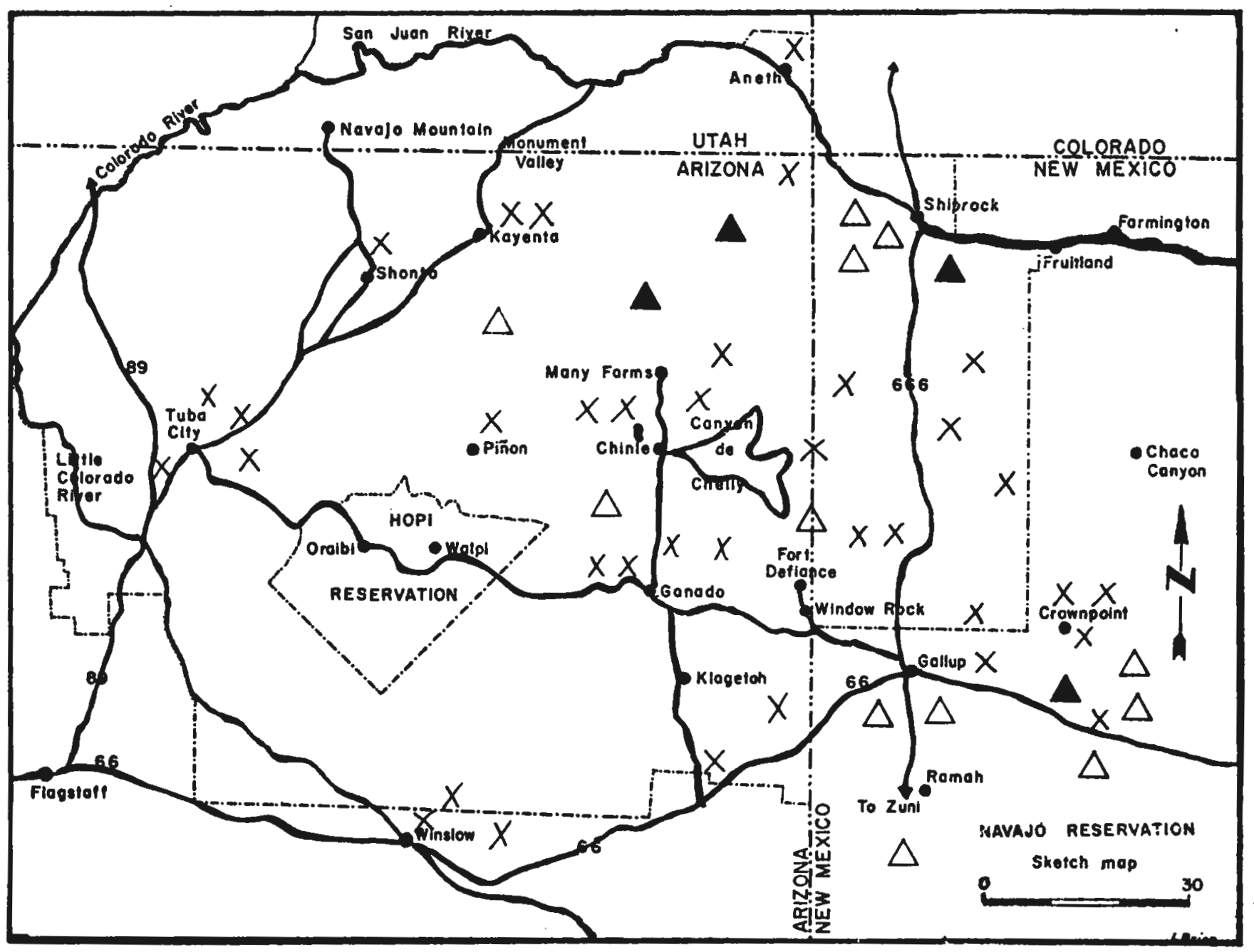

KEY: - $\triangle$ BIA Day Schools

- X BIA Boarding Schools

- $\triangle$ Tribal Contract Schools 
to encourage public schools to accept more Indians into their systems. Reports before the House in 1977 have recorded statements from school officials that the aid received from Acts such as the Johnson-0'Malley are often used to segregate the Navajo student from others in the school by developing separate classes and programs exclusively for the Indian student. ${ }^{24}$ In addition, information at these hearings cited three major deficiencies in the public school systems serving the reservation: large-scale deficit spending, overcrowded facilities and delayed appropriation of funding. Delays of funding have disrupted planning and contributed to underfunding because of the effects of inflation and have aggravated deficit spending because state funds cannot be be spent in anticipation of any special funding.

Other problems experienced by the Navajo student include the lack of uniform standards with each state setting its own requirements which the Navajo must meet for each grade level; language and cultural adjustment faced by the student who attends public schools; and the rural isolation of the reservation which results in long bus routes (often 60 miles round trip) and lack of opportunities to participate in extra-curricular activities.

The other school system, the community or contract schools, was authorized by the Self-Determination Act. The system consists of a series of schools operated by the Navajo Triba with funding from the Bureau of Indian Affairs.

24. Oversight Hearings on Indian Education before the Subcommittee on Education and Iabor, House of Representatives, 95th Congress, First Session (Washington, D.C., 1977). 
The Tribe and the BIA sign a contract which abdicates authority to the Navajo Tribe, subject to the approval of the Tribal Council. The educational emphasis in the contract schools is Navajo oriented with instruction in the Navajo language, a bicultural curriculum and workshops in traditional Navajo arts. As of 1980, there were four Navajocontrolled schools; Borrego Pass, Rock Point, Rough Rock and Ramah.

These community controlled schools constitute one of the most significant impacts of Nixon's policy and the subsequent legislation for self-determination. Many other changes, such as the institutionalization of bilingual programs in the Bureau of Indian Affairs' schools, the creation of Navajo parent advisory boards in the public schools and increased Federal funding for students in the state schools have developed in the educational systems serving the Navajo since the 1970's. However, the key method necessary to evaluate the policy of self-determination is a quantification of its impact through indicator analysis. In order to undertake this evaluation, certain decisions need to be made regarding what is being measured; the improvement of Indian educational achievement by an increase in self-determination. The question that the analysis must answer is whether this policy direction has achieved not only the goal of self-determination, but also a higher educational achievement level of the Navajo? The following chapter discusses the application of indicator analysis to the problem statement of assessing the changes in the education level since the implementation of the SelfDetermination Act. 
CHA PTER II

SOCIAL INDICATOR MODEL

\section{Introduction}

This chapter utilizes indicator analysis to measure the impact of self-determination policy on improving the educational achievement of the Navajo. The focus of the. chapter is on the conceptual framework with which the researcher approaches the data analysis. Information provided includes the definition of social indicators, the selection process of the data and its organization into a model. The next chapter analyzes the data and interprets the findings as they relate to the improvement of Indian educational achievement.

\section{Theoretical Framework}

The crucial step in indicator analysis is the design of the interpretive framework which organizes indicators into a model. A model facilitates the identification of key interrelationships between indicators and assesses their role in the overall social process under investigation (education). The rationale for the model is dependent on 
the notion of the use of indicators and their ability to measure the social process of education, assess policy direction and trends over time and evaluate the impact of particular policy decisions on the process under investigation. The defining characteristics of social indicators have three main attributes:

- They are normative statistics which measure changing conditions ;

- They are time series which compare over time or are disaggregated by other characteristics;

- They are theory based, tied to goals and based on the assumption of the predictability of group behavior.

The value of social indicators as a method to measure social conditions depends on an understanding of the operation of the educational process on the Navajo reservation in order to identify those indicators which reflect a clear concept of what is being measured and for what purpose. An understanding of the nature of the system allows the researcher to correctly identify types of data for the study and the relations to consider in the final analysis.

\section{The Model}

The model developed for this project (see Figure 4) is based on Land and Spilerman's social indicator model. 25 It attempts to simulate the complex social system of

25. Kenneth Land, Social Indicator Models. eds. Land and Spilerman (New York: Sage Foundation, 1975), p.18. 


\section{FIGURE 4}

SOCIAL INDICATOR MODEL

INPUT

OUTPUT

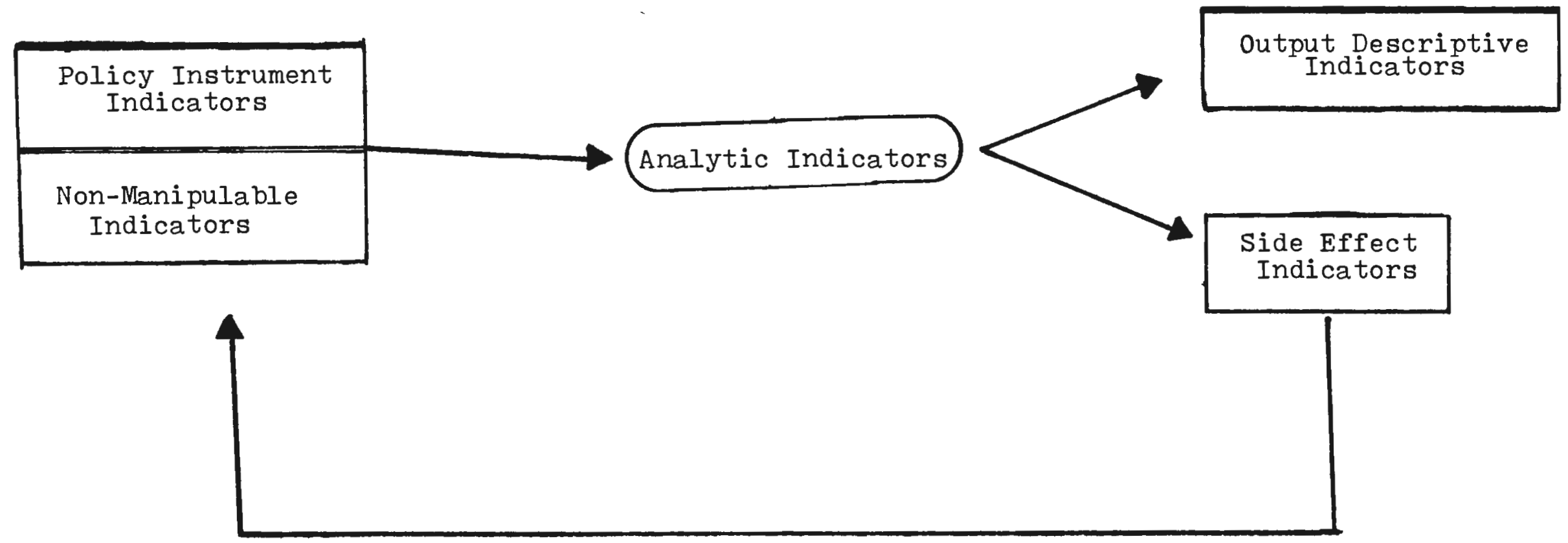


education in which change occurs through a series of linked variations in one or more indicators. The model results from an effort to understand the interrelationships between all social systems through an analysis of selected data. This analysis involves the interpretation of the model as a process of interaction between policy decisions and gozl formulation through which the reliability of the method is tested by predicting and ordering complex social processes. The components of the model are classified into five main types for analysis.

1. Policy Instrument Inäicators - directly manipulable by social policy and its decision-making process. 2. Non-Manipulable Indicators - general measures not manipulable by social policy. These indicators function as the basis for development of composite profiles which monitor general trends and social conditions over time. 3. Analytic Indicators - measures of the underlying relationships which affect the output (descriptive and side effect irdicators). Their purpose is to integrate indicators within the social system. 4. Output Descriptive Indicators - measures of the end products of the social process under analysis. They are a direct social system measurement which, in some ways, is a response to the analytic indicators.

5. Side Effect Indicators - measures of outputs of the social system model which are not of primary concern to the study, but provide indirect information on the variables of 
interest in the analysis (output descriptive indicators). The model illustrates these five main types of indicators in a visual graphic form similar to a flow chart. Analytic indicators occupy the central area as they integrate the input and output indicators and, in some ways, respond to changes in the policy instrument indicators. Side effect indicators are placed in a loop since they indirectly impact both the input and output of the social system model.

The selection process, which identified indicators within the five main types, required the use of a set of criteria which tested the data's reliability and acceptability as a measure and their relevance, to the overall social process under investigation (education). Tables II - XI list by type the indicators identified through this process as well as providing the purpose or objective of their selection.

The indicators selected for the output descriptive category concentrate on the end results of the process; these include such statistics as average school years by adults and the school enrollments of several levels of educational achievement. Statistics on enrollment, suspensions and dropouts are collected by school systems (public, Bureau of Indian Affairs and tribal contract) in order to isolate changes in the BIA and public school systems from the Navajo controlled contract schools.

The analytic indicators are a series of indicators which can positively or negatively affect the output 
TABLE II

SELECTED INDICA TORS BY TYPE: 1970 and 1980

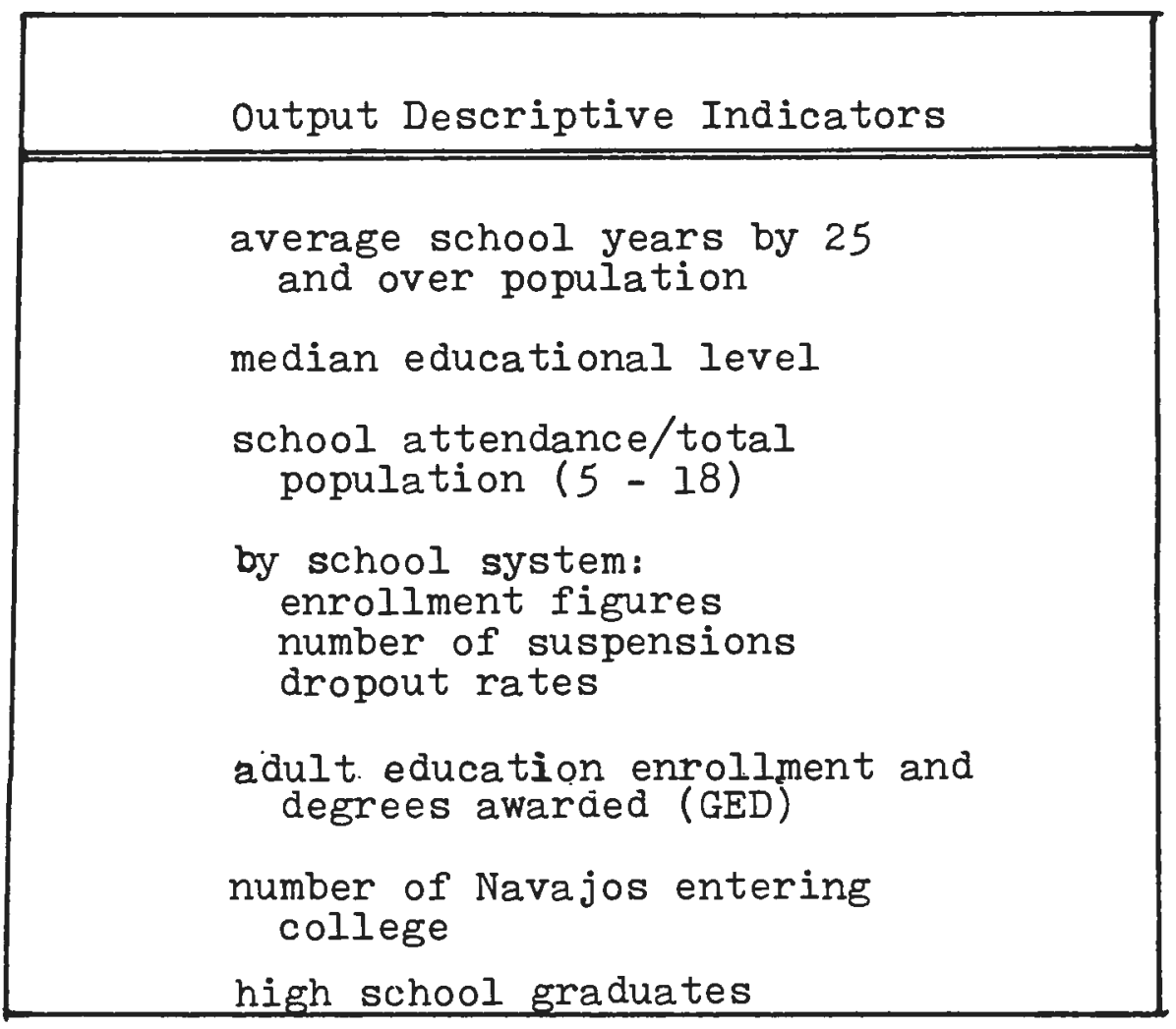


TABLE III

PURPOSE OF SELECTION

\begin{tabular}{|c|c|}
\hline Indicator & Purpose \\
\hline $\begin{array}{l}\text { Cutput Descriptive Indicators } \\
\text { Average school years completed } \\
\text { by } 25 \text { and over population } \\
\text { Median educational level } \\
\text { School attendance/total popu- } \\
\text { lation (5-18) } \\
\text { Adult education enrollment and } \\
\text { degrees awarded } \\
\text { Number of Navajos in college } \\
\text { High school graduates } \\
\text { By school system: } \\
\text { enrollment figures } \\
\text { suspensions } \\
\text { dropouts }\end{array}$ & $\begin{array}{l}\text { Measure success of educational } \\
\text { system and its changes over } \\
\text { time } \\
\text { Reflect quality of education } \\
\text { and social stability }\end{array}$ \\
\hline
\end{tabular}


TABLE IV

SELECTED INDICATORS BY TYPE: 1970 and 1980

\begin{tabular}{|l|}
\hline Analytic Indicators \\
\hline enrollment history \\
number of Navajo \\
teachers \\
number of Navajo \\
teacher aides \\
parent-teacher boards \\
(number by school \\
system) functions: \\
$\quad$ advisory \\
orientation programs \\
for non-Navajo \\
teachers \\
attitude of teachers, \\
students, parents \\
community involvement \\
in school system: \\
volunteer tutors \\
classroom helpers \\
attendance at public \\
meetings \\
\hline
\end{tabular}


TABLE V

PURPOSE OF SELECTION

Indicator

Purpose

\section{Analytic Indicators}

Enrollment history

Number of Navajo teachers and aides

Parent-Teacher Boards existence and function

Orientation programs for Non-Navajo teachers

Attitude of teachers, parents and students

Community involvement in school systems

Attendance at public meetings
Reflect changes in enrollment of each school system

Assess the commitment of school systems in hiring qualified Indian personnel

Record the effort of school systems to allow decisionmaking authority to involve parents

Assess the effort of school systems to prepare Non-Navajo teachers to meet special needs of Navajo children

Measure overall public perception of school systems and their ability to meet needs of Navajo children

Measure commitment of school system to encouraging participation of parent in all phases of learning environment

Assess community participation on school issues 
TABLE VI

SELECTED INDICATORS BY TYPE: 1970 and 1980

Policy Instrument Indicators

federal appropriation to education system (JOM)

federal approoriation for learning disabled and gifted children

programs for learning disabled

dollars/year/child spent in school system

bilingual programs: ESL

Navajo Language Arts

curriculum choice (courses

on Navajo history, arts ....)

educational legislation 
TABLE VII

PURPOSE OF SELECTION

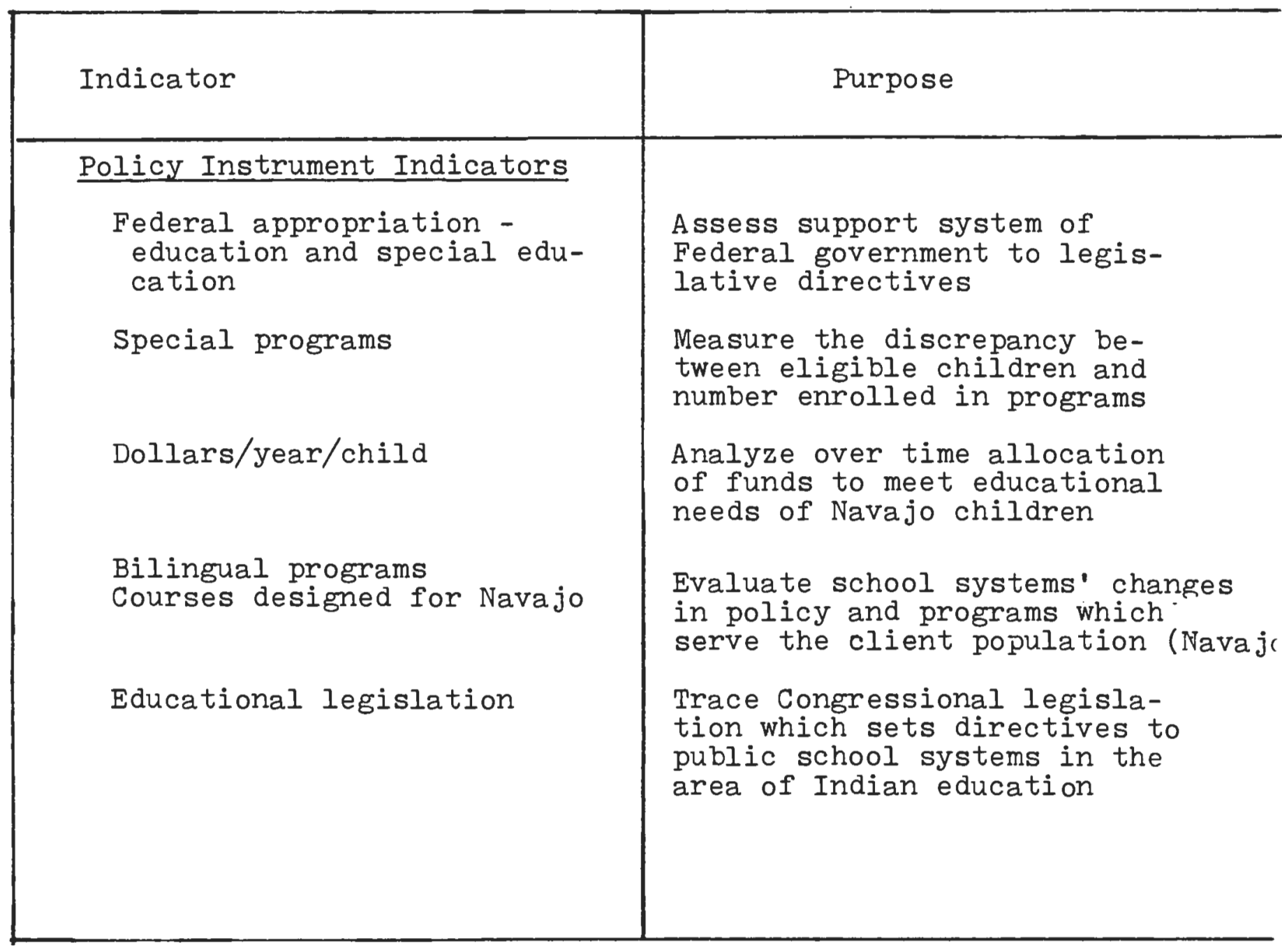


TABLE VIII

SELECTED INDICATORS BY TYPE: 1970 and 1980

\begin{tabular}{|c|c|}
\hline \multicolumn{2}{|c|}{ Non-Manipulable Indicators } \\
\hline Demographics: & $\begin{array}{l}\text { total population } \\
\text { population by age } \\
\text { median age } \\
\text { female head of household } \\
\text { number of families } \\
\text { families with children } \\
\text { less than } 18\end{array}$ \\
\hline Housing: & $\begin{array}{l}\text { household size } \\
\text { median number of rooms } \\
\text { year structure built } \\
\text { substandard houses } \\
\text { number of occupied units } \\
\text { median value of occupied } \\
\text { units }\end{array}$ \\
\hline Socio-Economic & $\begin{array}{l}\text { families below poverty } \\
\text { level } \\
\text { median income } \\
\text { median income by sex } \\
\text { cars available per household } \\
\text { unemployment/underemployment } \\
\text { class of worker } \\
\text { employment by sector }\end{array}$ \\
\hline $\begin{array}{l}\text { Stability/ } \\
\text { Participation level }\end{array}$ & $\begin{array}{l}\text { crime rate } \\
\text { divorce rate } \\
\text { voters in tribal elections } \\
\text { community groups }\end{array}$ \\
\hline Health & $\begin{array}{l}\text { birth rate/death rate } \\
\text { life expectancy } \\
\text { causes of death }\end{array}$ \\
\hline $\begin{array}{l}\text { Recreation/ Cultural } \\
\text { Support }\end{array}$ & $\begin{array}{l}\text { recreational programs } \\
\text { public transportation } \\
\text { cultural resources }\end{array}$ \\
\hline
\end{tabular}


TABLE IX

PURPOSE OF SELECTION

\begin{tabular}{|c|c|}
\hline Indicator & Purpose \\
\hline Non-Manipulable Indicators: & \\
\hline Demographics & $\begin{array}{l}\text { Profile Indian community; } \\
\text { analyze growth trends and } \\
\text { responsive change in edu- } \\
\text { cational system }\end{array}$ \\
\hline Housing & $\begin{array}{l}\text { Assess overall quality of } \\
\text { physical environment and } \\
\text { social conditions on reservation }\end{array}$ \\
\hline Socio-Economic & $\begin{array}{l}\text { Evaluate quality of life con- } \\
\text { ditions; estimate economic need } \\
\text { of families and students and } \\
\text { the accessibility to educational } \\
\text { opportunities }\end{array}$ \\
\hline Participation Level & $\begin{array}{l}\text { Assess stability of family and } \\
\text { cohesion of community; measure } \\
\text { identification of Indian com- } \\
\text { munity with current issues. }\end{array}$ \\
\hline Health & $\begin{array}{l}\text { Measure quality of life and } \\
\text { social isolation/alienation of } \\
\text { Indian population }\end{array}$ \\
\hline Recreation/Cultural Support & $\begin{array}{l}\text { Assess quality of life as it re- } \\
\text { lates to availability of leisure } \\
\text { activities }\end{array}$ \\
\hline
\end{tabular}


TABLE $X$

SELECTED INDICATORS BY TYPE: 1970 and 1980

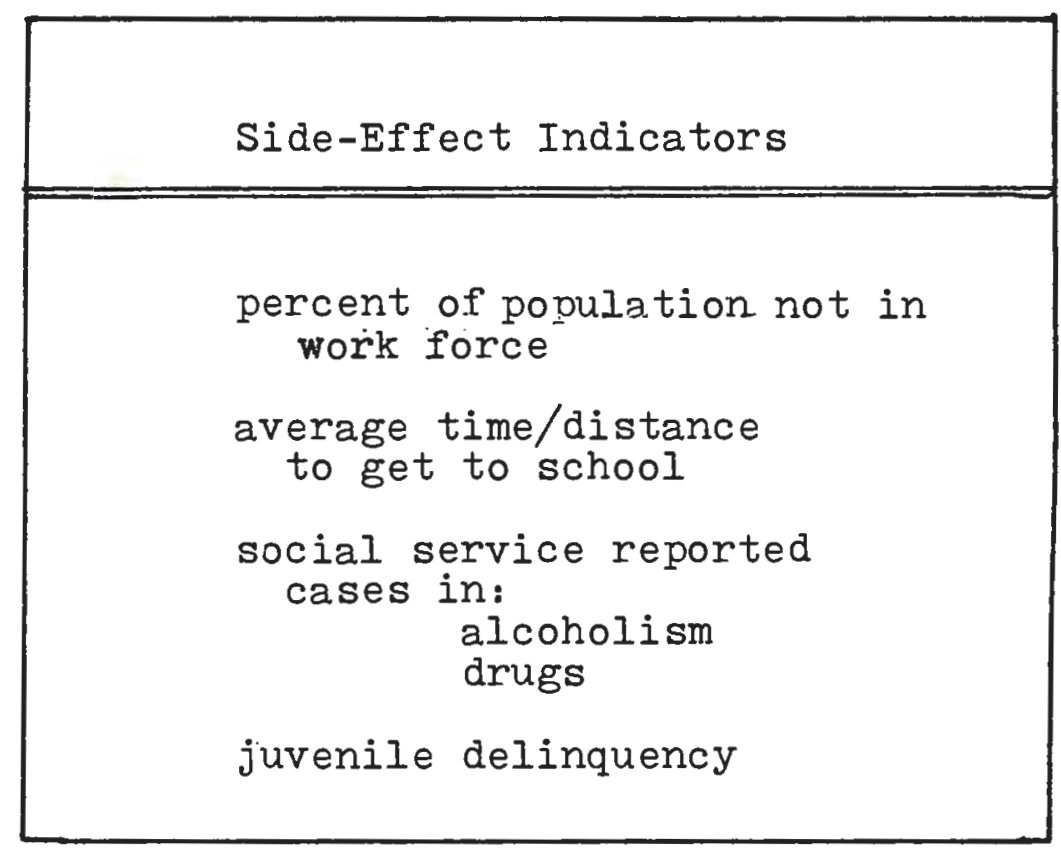


TABLE XI

PURPOSE OF SELECTION

\begin{tabular}{|c|c|}
\hline Indicator & Purpose \\
\hline Side Effect Indicators & \\
\hline $\begin{array}{l}\text { Percent of population not } \\
\text { in work force }\end{array}$ & $\begin{array}{l}\text { Measure economic need of } \\
\text { population and quality of } \\
\text { life conditions }\end{array}$ \\
\hline $\begin{array}{l}\text { Average time/distance } \\
\text { to get to school }\end{array}$ & $\begin{array}{l}\text { Assess equal opportunity } \\
\text { to education of Indian chil- } \\
\text { dren }\end{array}$ \\
\hline $\begin{array}{l}\text { Social Service cases in: } \\
\text { alcoholism } \\
\text { drugs }\end{array}$ & $\begin{array}{l}\text { Measure alienation/social } \\
\text { isolation of Indian population }\end{array}$ \\
\hline $\begin{array}{l}\text { Juvenile delinquency cases } \\
\text { in Tribal Courts }\end{array}$ & $\begin{array}{l}\text { Measure alienation/social } \\
\text { isolation of Indian children }\end{array}$ \\
\hline
\end{tabular}


descriptive and side effect types. For example, a higher number of Navajo teachers may improve school attendance and increase the number of graduates at all levels. The input of parent-teacher boards can affect the educational system since many of the BIA and public schools do not have members who represent the Navajo tribe or have boards that serve only in an advisory capacity. Another indicator, community involvement in schools, is intended to measure participation of the Navajos beyond a school board organization.

The attitude of teachers, students and parents is a primary data source which monitors the public perception of the role of the school system in meeting Indian education requirements.

These analytic indicators measure self-determination by assessing changes in the number of Navajo teachers and more involvement of the Navajo in the school systems. If there is a corresponding change in the output descriptive indicators, correlation of the information is possible.

The policy instrument indicators are generally measurements of policy decisions which impact output indicators. The indicator, bilingual programs, records not only the number of such programs, but also the type of program. The Navajo language arts program is designed by the Navajo tribe specifically for use by their children in schools of all three systems. Other indicators in this category 
measure the input of Navajo oriented programs as well as the appropriation given to organize the programs and provide for the educational needs of the Navajo students by the Federal government. The success or failure of the self-determination process often is dependent on the fiscal resources allocated to operate many of the new programs.

Side effect indicators are responsive to the output measures and the input indicators in the overall model. For example, the number of reported cases of alcoholism and juvenile delinquency may be a response to the low educational achievement of the Navajo or it may be that the cases are a reaction to the breakdown of other social systems which are then causing the low educational achivement of the Navajo. Another indicator, average distance to school, also affects output since the mileage routes can create problems of accessibility to school facilities on a rural reservation such as the Navajo which is approximately 24,000 square miles.

The indicators selected under the non-manipulable category provide general quality of life characteristics. They supply information on the overall physical and social environment within which the educational system operates.

\section{Data Base}

In order to measure the impact of the policy of selfdetermination on the improvement of the educational 
achievement of the Navajo, several decisions concerning the collection of data were necessary. The year selected to represent conditions on the reservation before the new policy and subsequent legislation was enacted is 1970. In order to allow maximum implementation of programs under the policy, the other year chosen is 1980.26 The analysis of indicators within this time frame is considered a replication study since it is based on the collection of macro data which utilize information only on aggregate proportions of individuals in each measured state for each time period.

Tables XII- XVI identify pertinent information for each category of indicators, including the sources of information for each variable, their availability in the designated time period and the necessary changes in direction during the decade which would confirm for the study an increase in the educational achievement level of the Navajo through self-determination.

Appendix $E$ contains a more detailed description of the data sources and explains problems of availability and reliability.

26. The unavailability of data for certain indicators in 1980 required the substitution of 1979 information as noted. 
TABLE XII

DATA BASE CHARACTERISTICS

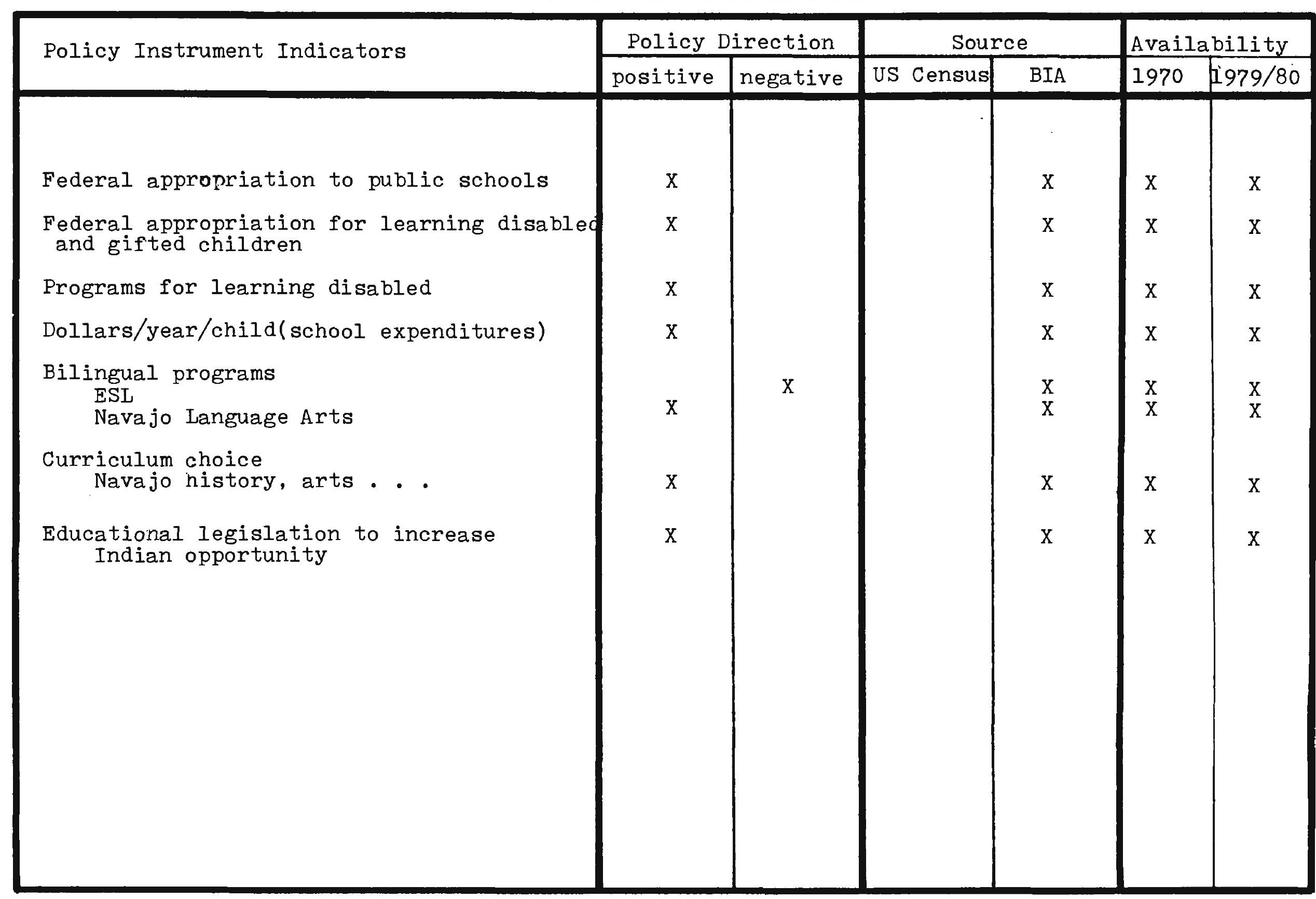


TABLE XIII

DATA BASE CHARACTERISTICS

\begin{tabular}{|c|c|c|c|c|c|c|}
\hline \multirow{2}{*}{ Non-Manipulable Indicators } & \multicolumn{2}{|c|}{ Policy Direction } & \multicolumn{2}{|c|}{ Source } & \multicolumn{2}{|c|}{ Availability } \\
\hline & positive & negative & US Census & BIA & 1970 & 1980 \\
\hline \multicolumn{7}{|l|}{ Demographics: } \\
\hline $\begin{array}{l}\text { Total population } \\
\text { Population by age } \\
\text { Median age } \\
\text { Female head of household } \\
\text { Number of families } \\
\text { Families with children less than } 18\end{array}$ & $\begin{array}{l}\mathrm{X} \\
\overline{-} \\
\overline{\mathrm{X}} \\
\mathrm{X}\end{array}$ & - & $\begin{array}{l}X \\
X \\
X \\
X \\
X \\
X\end{array}$ & & $\begin{array}{l}X \\
X \\
X \\
X \\
X \\
X\end{array}$ & $\begin{array}{r}X \\
X \\
X \\
X \\
X \\
N A\end{array}$ \\
\hline Housing: & & & & & & \\
\hline $\begin{array}{l}\text { Household size } \\
\text { Mədian number of rooms } \\
\text { Year structure built } \\
\text { Substandard houses } \\
\text { Number of occupied units } \\
\text { Median value of occupied units }\end{array}$ & $\begin{array}{l}- \\
- \\
X \\
X\end{array}$ & $\overline{\bar{x}}$ & $\begin{array}{l}X \\
X \\
X \\
X \\
X \\
X\end{array}$ & & $\begin{array}{l}X \\
X \\
X \\
X \\
X \\
X\end{array}$ & $\begin{array}{l}\text { X } \\
\text { NA } \\
\text { NA } \\
\text { NA } \\
\text { NA } \\
\text { NA }\end{array}$ \\
\hline \multicolumn{7}{|l|}{ Socio-Economic: } \\
\hline $\begin{array}{l}\text { Families below poverty level } \\
\text { Median income } \\
\text { Median income by sex } \\
\text { Cars available per household } \\
\text { Unemployment/underemployment } \\
\text { Class of worker } \\
\text { Employment by sector }\end{array}$ & $\begin{array}{l}X \\
X \\
X \\
- \\
-\end{array}$ & $\begin{array}{l}X \\
- \\
-\end{array}$ & $\begin{array}{l}X \\
X \\
X \\
X \\
X \\
X \\
X\end{array}$ & & $\begin{array}{l}X \\
X \\
X \\
X \\
X \\
X \\
X\end{array}$ & $\begin{array}{l}\text { NA } \\
\text { NA } \\
\text { NA } \\
\text { NA } \\
\text { X* } \\
\text { NA } \\
\text { NA }\end{array}$ \\
\hline $\begin{array}{l}\text { Stability/Participation Level: } \\
\text { Crime rate } \\
\text { Divorce rate } \\
\text { Voters in tribal elections }\end{array}$ & $\mathrm{X}$ & $\begin{array}{l}X \\
X\end{array}$ & & $\begin{array}{l}X \\
X \\
X\end{array}$ & $\begin{array}{r}\mathrm{NA} \\
\mathrm{X} \\
\mathrm{X}\end{array}$ & $\begin{array}{l}\text { NA } \\
\text { NA } \\
\mathrm{X}\end{array}$ \\
\hline
\end{tabular}

* Available for 1975 only 
TABLE XIII (cont.)

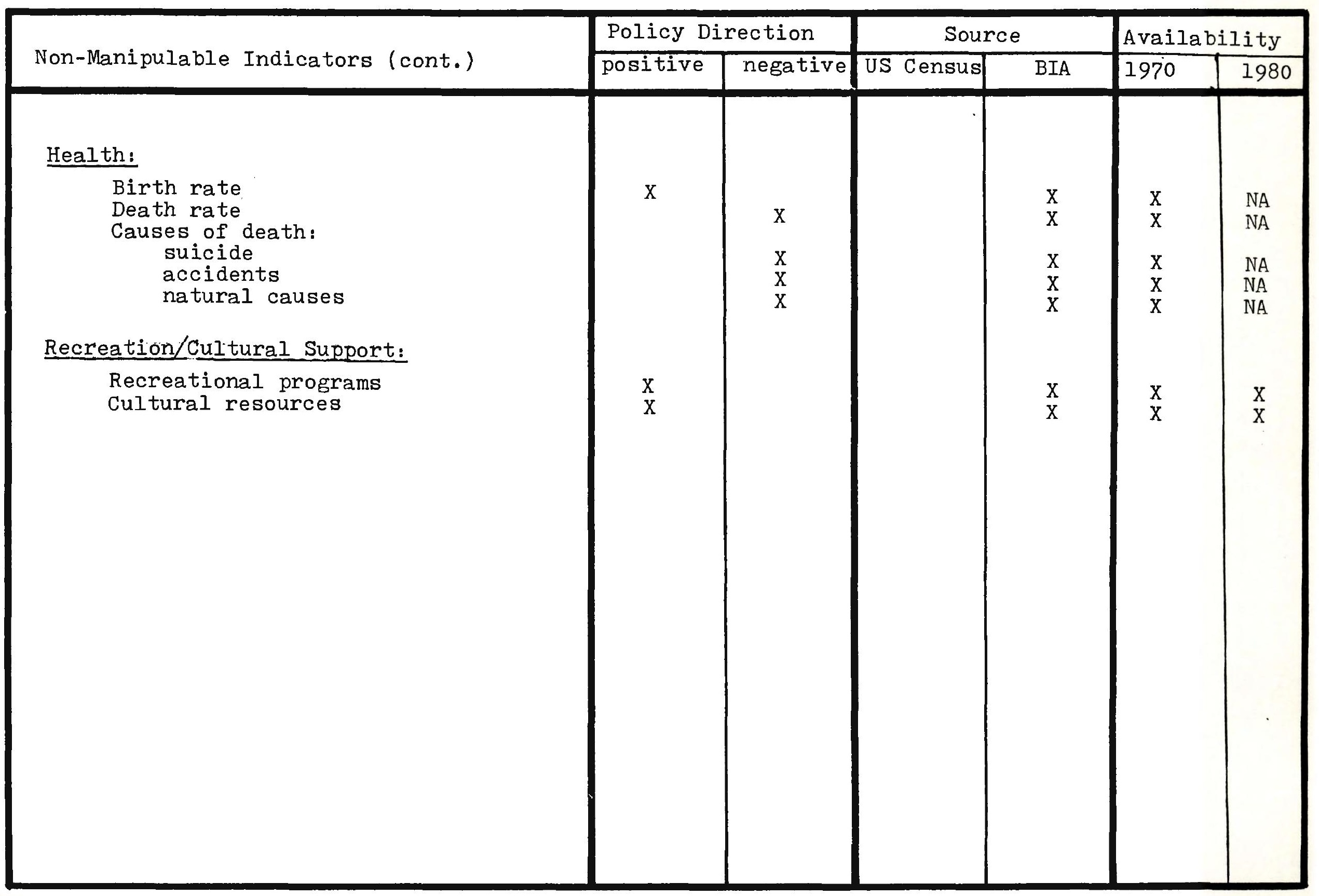


TABLE XIV

DATA BASE CHARACTERISTICS

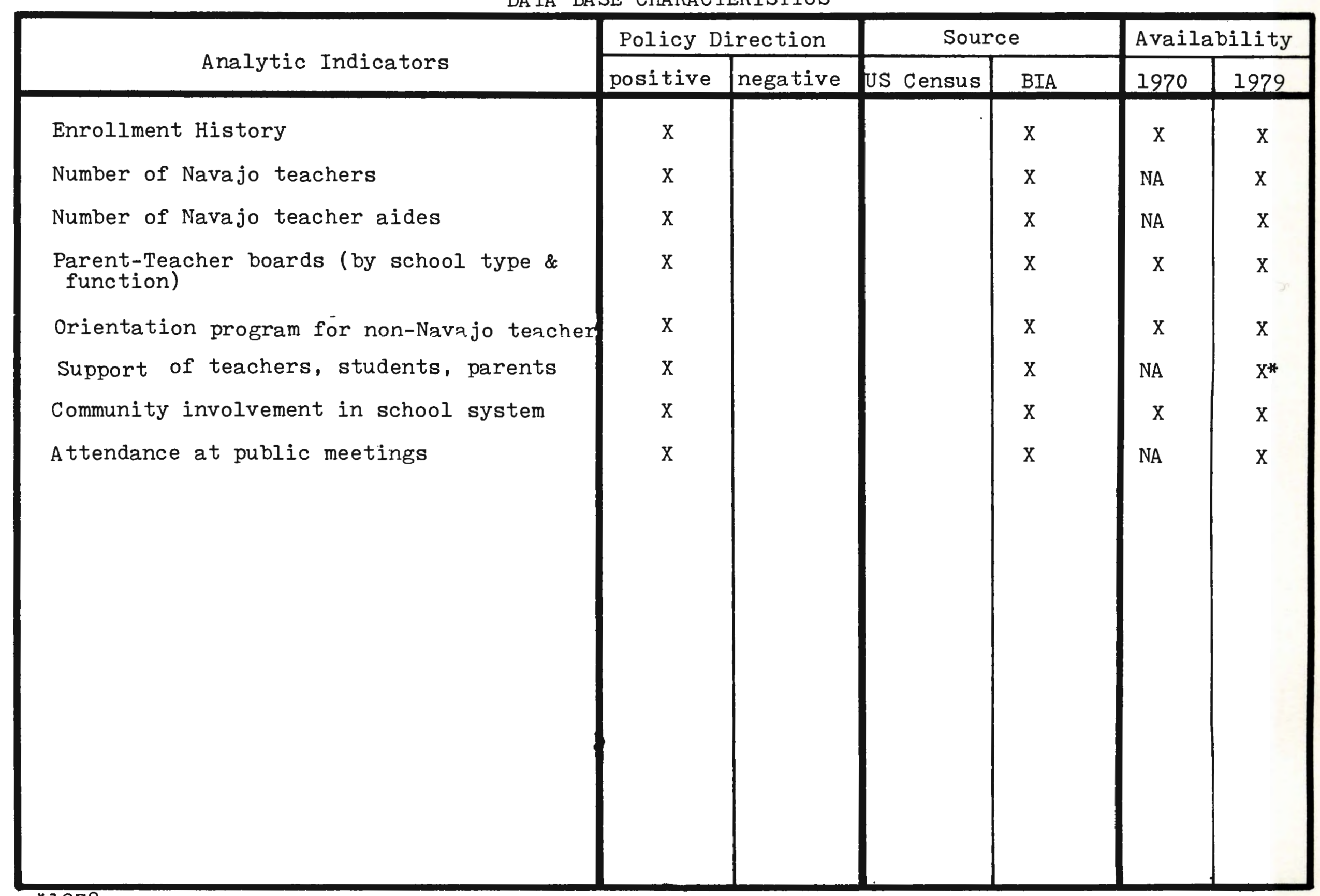

*1978 survey 
DATA BASE CHARACTERISTICS

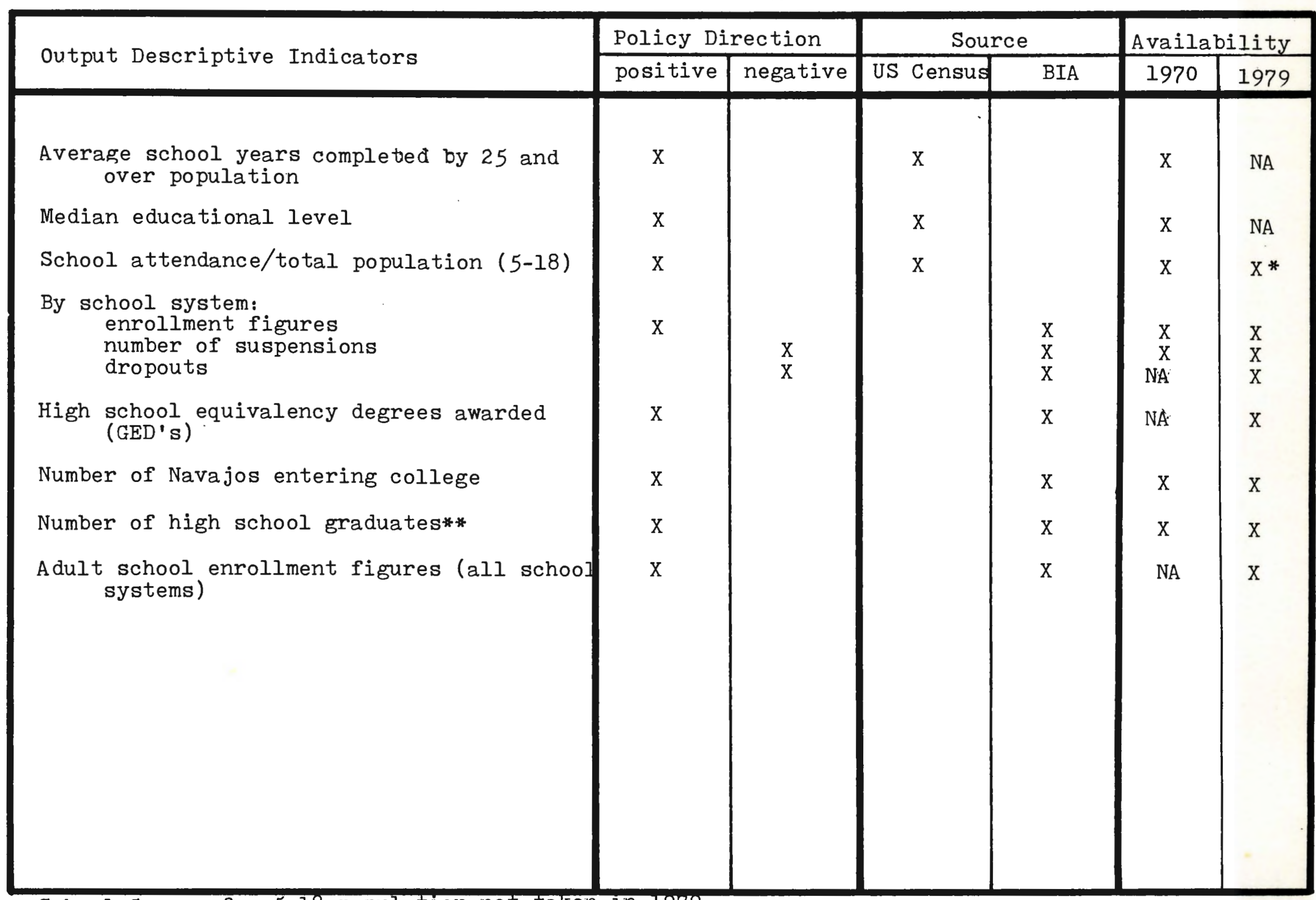




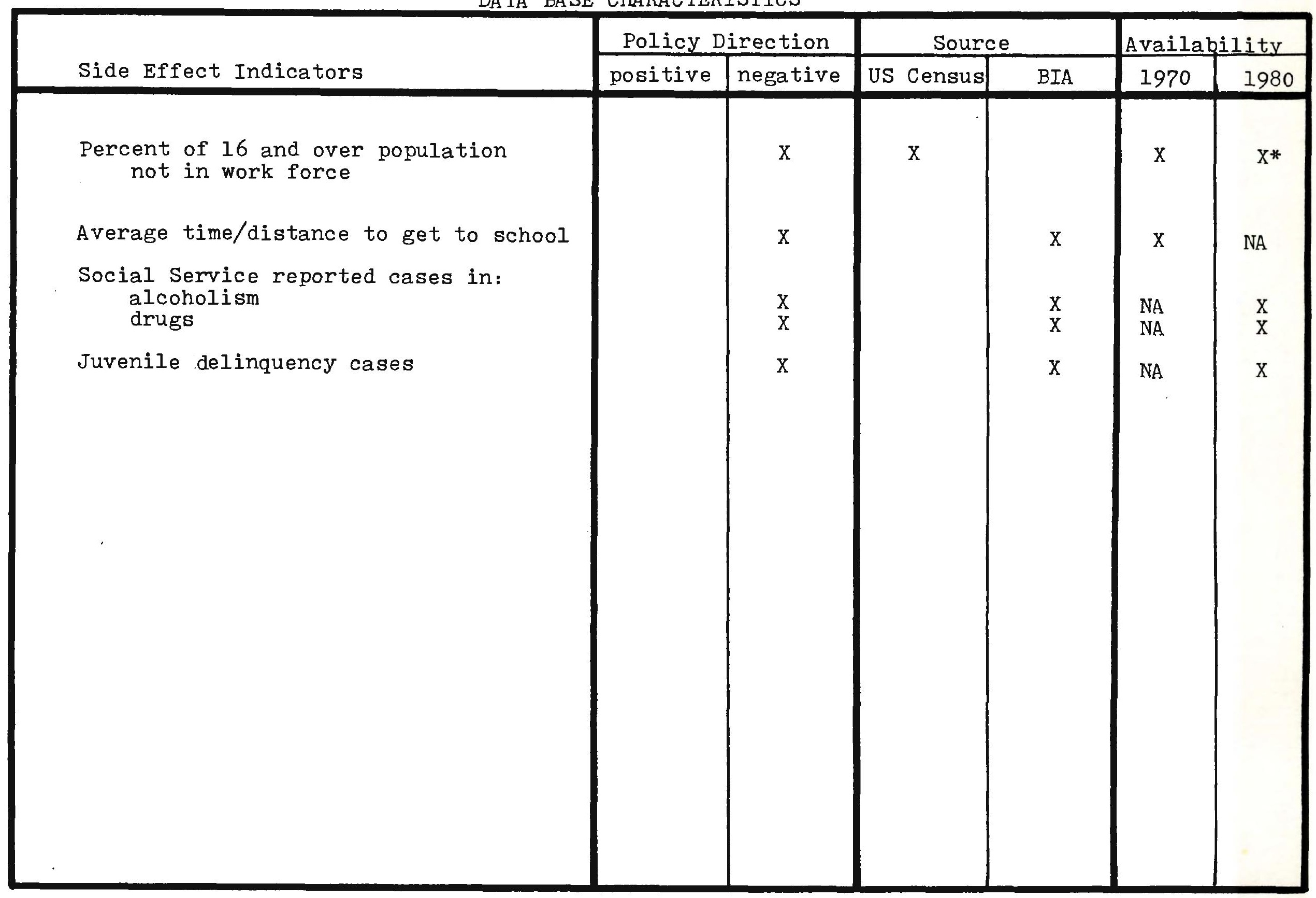

*Information available for 1975 only 
CHAPTER III

INDICATOR ANALYSIS

\section{Introduction}

The data compiled for the study is analyzed with reference to its measurement of self-determination and its role in improving educational achievement. The analysis is organized first by types of indicators and then by a general findings section which summarizes the five categories and discusses the final results of the research.

\section{Policy Instrument Indicators}

Data collected in this category (see Table XVII) shows an increasing commitment of the Federal government to Navajo education. From 1970 to 1980, appropriation to public schools and to Title I programs has increased by 1.3 and 6 million, respectively. However, these figures can be misleading. When the public school appropriation is calculated per Navajo student, the funding level has decreased by 46 percent during the decade. A similar trend is evident in the BIA and contract schools with a 23 percent decrease in funding available to meet the needs of the Navajo student. 
TABIE XVII

DATA COMPILATION

\begin{tabular}{|c|c|c|c|c|c|}
\hline $\begin{array}{c}\text { Policy Instrument } \\
\text { Indicators }\end{array}$ & 1970 & 1972 & 1977 & 1979 & $\begin{array}{l}\text { Percent } \\
\text { Change }\end{array}$ \\
\hline $\begin{array}{c}\text { Federal appropri- } \\
\text { ation to public } \\
\text { schools }\end{array}$ & $\$ 4$ mill. & - & - & $\$ 5.3 \mathrm{mill}$ & 32.5 \\
\hline $\begin{array}{l}\text { Federal appropri- } \\
\text { ation to Title } \\
\text { I programs: }\end{array}$ & $\$ 1$ mill. & - & - & $\$ 7 \mathrm{mill}$ & 600.0 \\
\hline $\begin{array}{c}\text {-number of projects } \\
\text {-number of children } \\
\text { - percent of eli- } \\
\text { gible children }\end{array}$ & $\begin{array}{l}74 \\
\text { NA } \\
\text { NA }\end{array}$ & $\begin{array}{l}58 \\
\text { NA } \\
\text { NA }\end{array}$ & $\begin{array}{l}58 \\
229 \\
65.2^{1}\end{array}$ & $\begin{array}{l}61 \\
12,689 \\
74.2^{1}\end{array}$ & $(17.6)$ \\
\hline $\begin{array}{l}\text { Expenditures per } \\
\text { pupil (BIA and } \\
\text { contract schools) } \\
\text { Expenditures per } \\
\text { pupil (public } \\
\text { schools) }\end{array}$ & $\begin{array}{l}\text { NA } \\
\$ 279\end{array}$ & $\$ 3,497^{2}$ & $\$ 2,374^{2}$ & $\begin{array}{l}\$ 2,689^{2} \\
\$ \quad 151\end{array}$ & $\begin{array}{l}(23.1) \\
(46.0)\end{array}$ \\
\hline
\end{tabular}

1. Percent calculated to total eligib].e children (1977 $-351 ; 1979-17,09$ :

2. Figure shown is mean and includes boarding and day schools.

$($ ) = negative number 
The policy instrument indicators which show positive changes in the school systems for the Navajo include the percentage of eligible children who are being served by Title I programs. The increase in appropriation has achieved a corresponding increase of nine percentage points by 1979 in the number of children enrolled in the programs. Only 25 percent of eligible children in this year were not covered under the programs offered.

Several other indicators for which actual data figures are not available support the trend toward self-determination. According to the Navajo Division of Education, curriculum choice has been expanded from 1970-1980 with Navajo courses now offered in all three school systems. The development of the Navajo Language Arts Programs (NAIAP) has resulted in a phasing out of the Fries-Rojas method of English as a Second Language (ESL) which was the only language arts program available in the BIA and public schools in 1970. In 1975. NALAP was developed by teachers and educational specialists in the Navajo area in order to better meet the special needs of Navajo school children. In 1980, all contract schools and 28 BIA schools were using the new method. As reviewed in Chapter I, educational legislation has increasingly moved toward self-determination for the Navajo in the area of education. The Johnson-0'Malley plan for the state of Arizona (Appendix $C$ ) and the Tribal Education plan (Appendix D) were authorized under the legislation implmenting the policy directives of the 1970's. The significant policy statements under the JOM plan of Arizona 
concern the state's commitment to the creation of Indian Committees (Appendix C, Policy M) and the recruitment of Navajo members of the school board. Although the effectiveness of the policy is not documented, these new statements on the role of public schools in providing Indian education were developing by 1980. The tribal education plan follows a similar approach by articulating its commitment to increasing the role of the Navajo in the education process. It is still too early to evaluate the implementation process of the plan in meeting the responsibilities delegated to the Board(Appendix D, Article VII) in 1979. However, it is important to note that by 1980 the framework for the improvement of self-determination was set.

When analyzing the data from a self-determination perspective, the overall policy instrument indicators show a response to the policy directive of self-determination. However, appropriation per Navajo student is decreasing which can cause certain budget constraints in program and curriculum development which is necessary to meet the needs of Navajo students in public and BIA schools. The effectiveness of the tribal plan can be limited if funding assistance continues to decrease at the Federal level. The one indicator which shows a positive change relates to the Title I progams. Although the number of projects declined in the decade, the higher appropriation has increased the number of children served under the program. This achievement can stabilize Navajo school enrollment, 
since these programs focus on the special needs of the Navajo by individualizing classroom services in areas such as language arts, tutoring and home/school counseling.

\section{Non-Manipulable Indicators}

These indicators supply information on the Navajo community and its physical and social environment for the decade, 1970-1980. From an educational perspective, the more significant indicators are in the area of demographics. The overall Navajo population is increasing dramatically with an 84 percent increase during the decale. This large increase is noted in every age group and also in the increasing number of families. Although data are not available on the number of families with children under eighteen for 1980, it is assumed that this category increased as well. The increasingly younger population (1980 median age of 18.8 years) is a significant trend for educational systems since the improvement of the quality of life for the Navajo depends on designing educational systems which will meet the needs of a population which will be placing more demands on the schools' programs and facilities.

The housing indicators reveal overcrowded conditions and a high number of poor quality houses. When household size is correlated with the median number of rooms, it is evident that many homes on the reservation do not have adequate spatial requirements for their families. The high 
TABLE XVIII

DATA COMPILATION

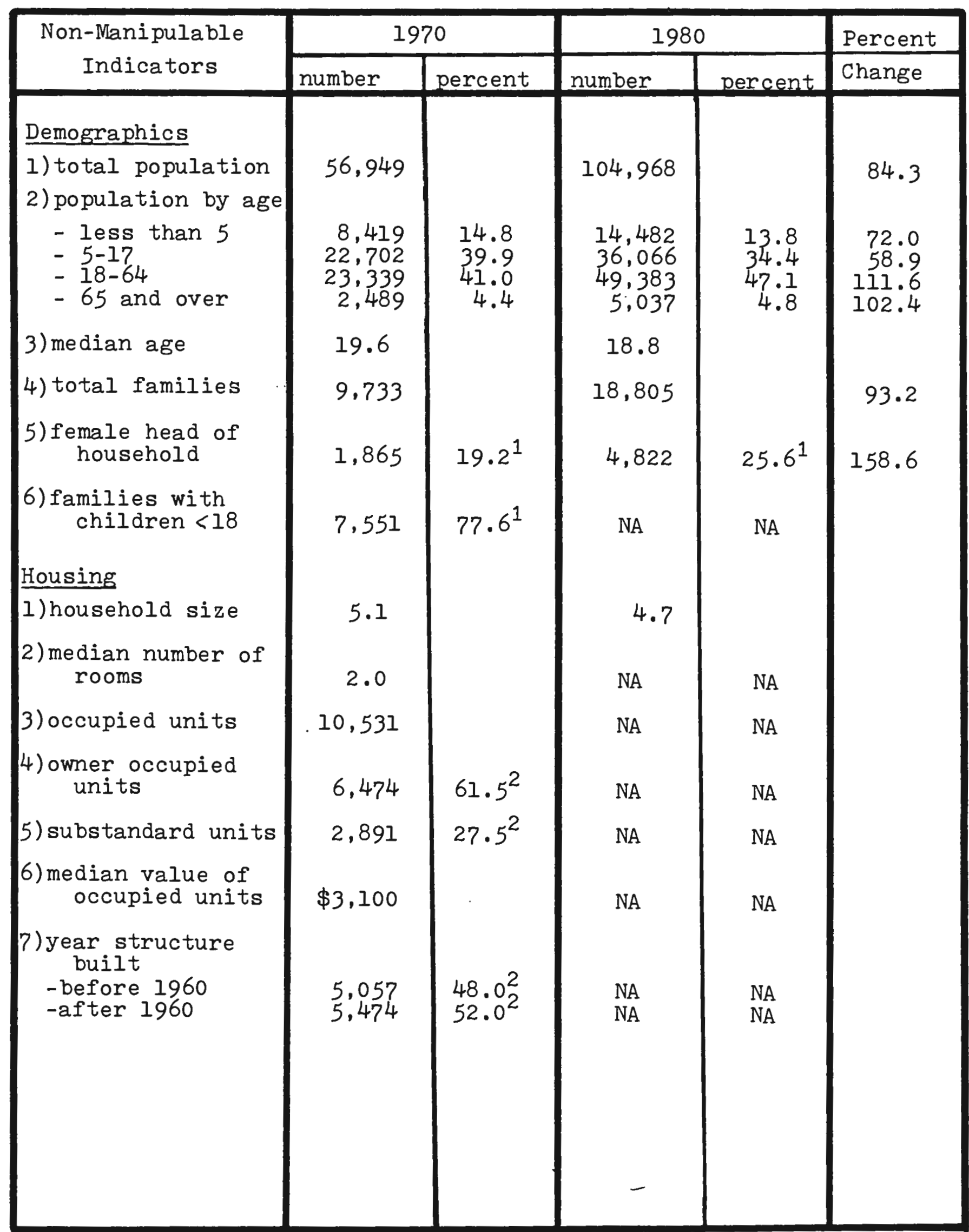

1. Percent calculated to total number of families

2. Percent calculated to total number of occupied units 
TABIE XVIII (cont.)

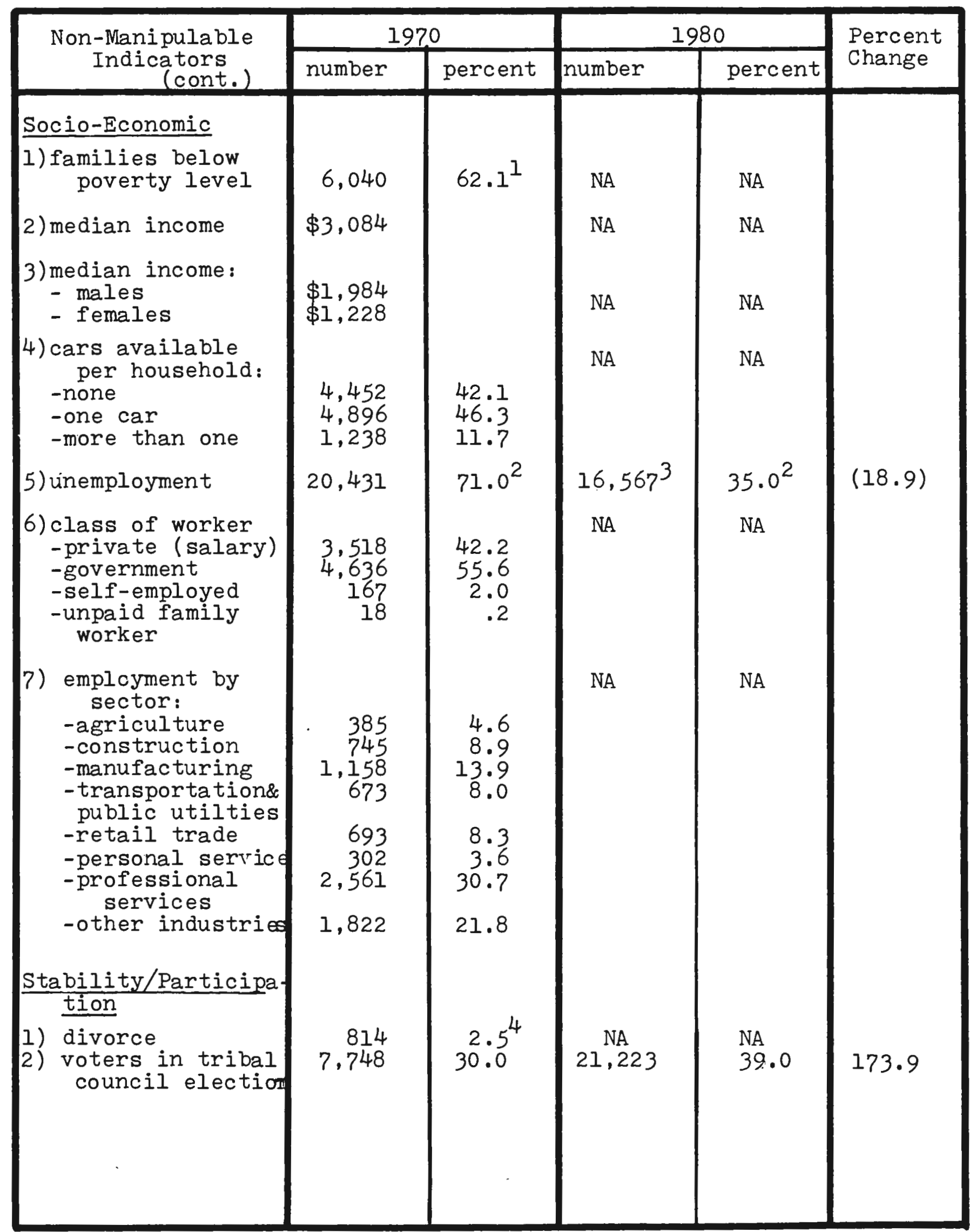

1. Percent calculated to total number of families

2. Percent calculated to 16 and over population: 1970-28,770;1975-47,31r

3. 1975 figure

4. Percent calculated to 18 and over population 
TABLE XVIII (cont.)

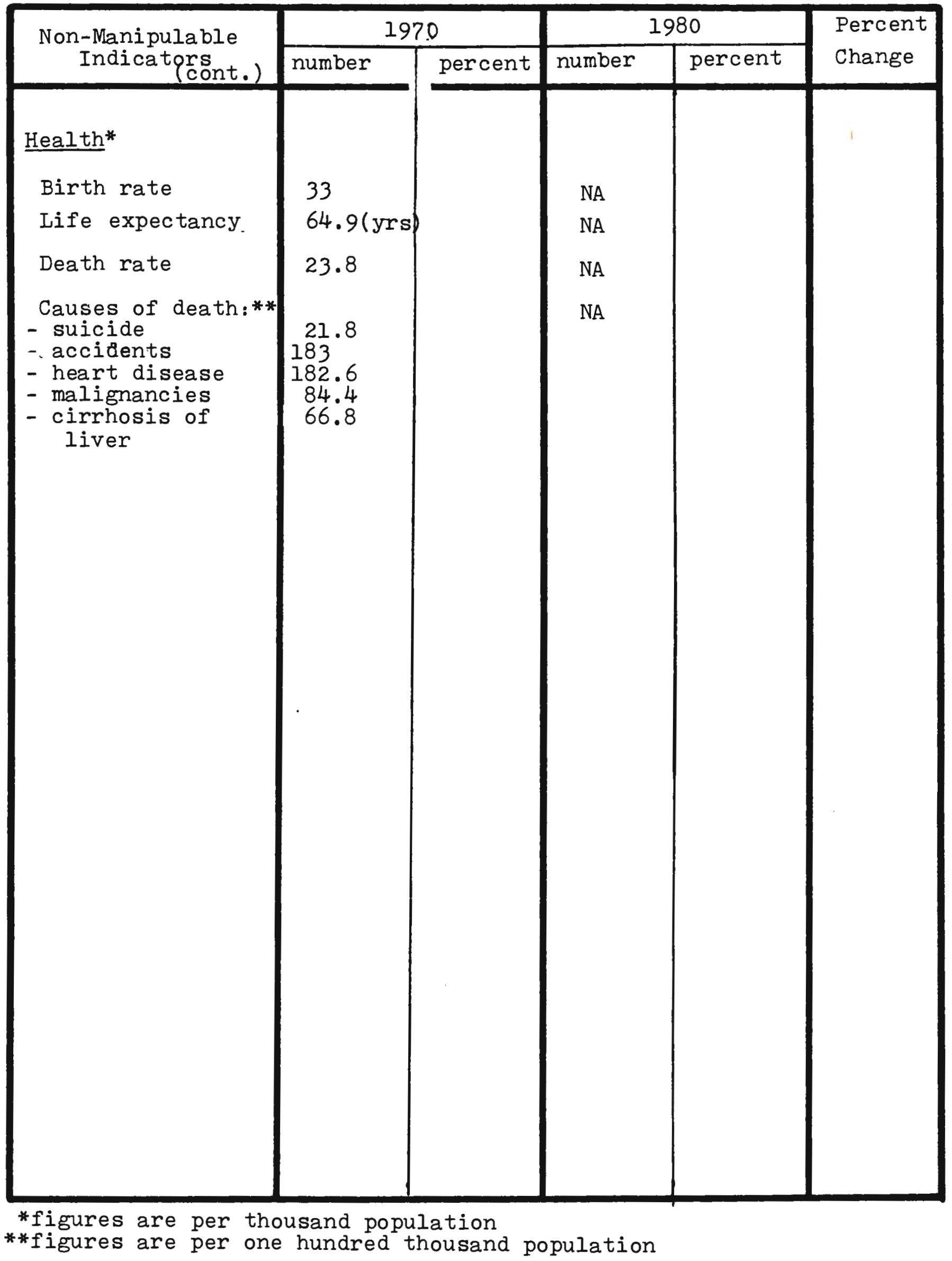


number of houses in 1970 which lack complete plumbing facilities (28 percent) verify the lack of a quality physical environment for many Navajo families.

According to the socio-economic indicators, the need for economic development of the Navajo Nation is a critical goal. Approximately 62 percent of all families were below the poverty level in 1970 and median income was $\$ 3,084$. Unemployment was considerably higher in 1970 than in 1980, which shows some improvement in reservation economy. However, 35 percent of the population unemployed in 1975 is an extremely high figure. Of those who do work, over 55 percent received their salary through federally sponsored government programs. Employment by sector reveals one of the main difficulties with increasing Navajo economic opportunities. The low percentage of Navajo Indians in the services and retail trade sectors means that most reservation income is spent off the reservation or with non-Indian owned businesses. The economic development of the reservation is needed to support Indian self-determination. Until 1980 Census figures are released in this category, it can be assumed that the Navajo reservation has not yet assumed tribal control of their economy. Until this is accomplished, the high numbers of unemployment and the low standard of living on the reservation will continue to exist.

Transportation, represented by the indicator, cars available per household, is related to problems of accessibility. In 1970, 42 percent of all households had no cars 
and 46 percent had only one vehicle available. These statistics, in combination with a poor road system and long bus routes verify some of the problems for education and other social processes. The limited accessibility isolates Indian children from participation in school and extra curricular activities and often discourages daily attendance in the schools.

Quality of life statistics for 1970 support the low standard of living experienced by the Navajo. Life expectancy is only 65 years ( 5 years lower than the overall 1970 United States figure) and the death rate is 4.6 times higher than the national figure of 19.2. Causes of death emphasize some of the social problems of reservation life. For example, suicides are double the national figure of 11.3 per one hundred thousand persons. The interrelationships of all these indicators selected is revealed in the statistics covered under the area of stability/participation (see Table XVIII). The combination of variables such as poor accessibility, social isolation and alienation can negatively affect participation. The indicator, voters in tribal elections, shows that the percentage from 1970 to 1980 increased by nine percentage points, representing only 39 percent of the total eligible population in 1980. Although no quantification is available on community groups, there has been significant improvement in the establishment of a network during the decade. Groups which have organized in the decade include a health care organization 
which travels throughout the reservation providing counseling on home care and a housing authority which has developed programs to educate the Navajo on renovation and repairs to older housing stock. The significance of these groups is that they bring their services to the people who are often isolated from the larger centers of activity on the reservation. One other important development in the Navajo community is the group project. on irrigation. This project is operated by a tribal enterprise which is constructing an irrigation system to bring land under agricultural use. When this project is completed, it will bring approximately 110,000 acres under irrigation which will provide more jobs and an additional source of revenue to the Navajo population.

Other indicators selected to assess the stability of the community, crime rate and divorce rate, were not available for the years under study.

The recreation/cultural support area had no quantifiable information available. However, a spokesperson for the Navajo Divison of Education stressed that the recreation system appears to be responding to self-determination during the past decade. The development of summer recreation programs for the children located at the Navajo Community College in Tsailee, Arizona, and the new courses and facilities at the Window Rock Community Center on Navajo arts and crafts provide needed activities on the reservation. However, the continuing poor road system and isolation make it difficult 
to achieve equal opportunity to all Navajo in supplying recreational opportunities.

In sum, the non-manipulable indicators present a profile of the Navajo as a community which suffers from lack of oppotunities; in education, economics, health care and transportation. Since many statistics are not available for 1980, it is difficult to assess accurately the improvement in these areas. However, most Indian leaders believe the articulated goals of self-determination and self-sufficiency have resulted in noticeable improvements in the quality of reservation life and the development of a sense of commitment to the community. The findings section of the chapter evaluates the role of self-determination more fully.

\section{Analytic Indicators}

This category monitors more intensively the changes over time in the educational system. Enrollment history reveals several significant trends in the three school systems. The more positive changes with reference to self-determination and improvement in education achievements are:

- the decreasing number of students who are enrolled in Beginners classes (see Table XIX) from 1970 to 1979. - the decline in BIA school attendance during the decade. This change is the result not of a decreasing school population but of the closing of five BIA school during time span; the opening of the four contract schools 


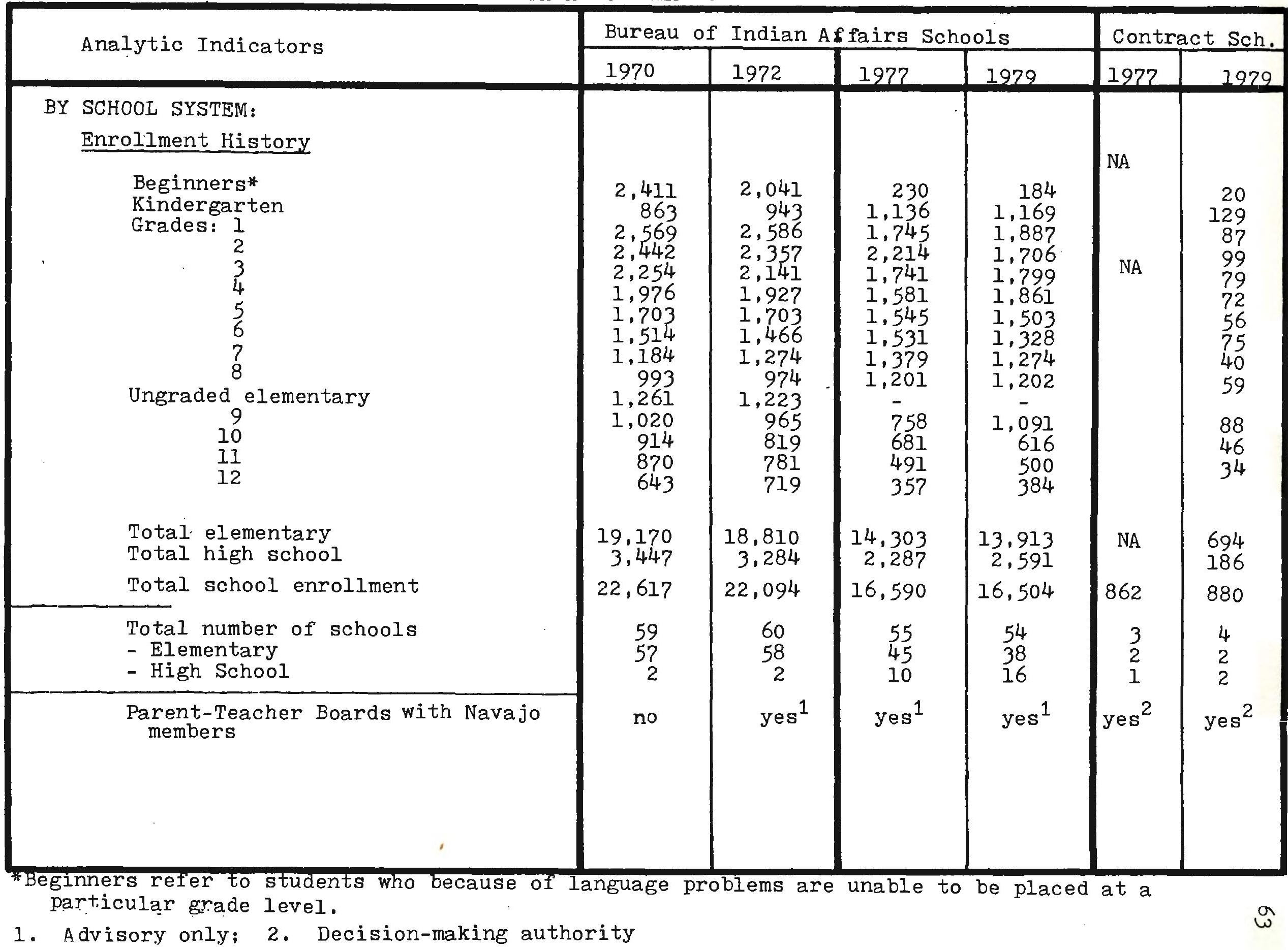


TABLE XIX (cont.)

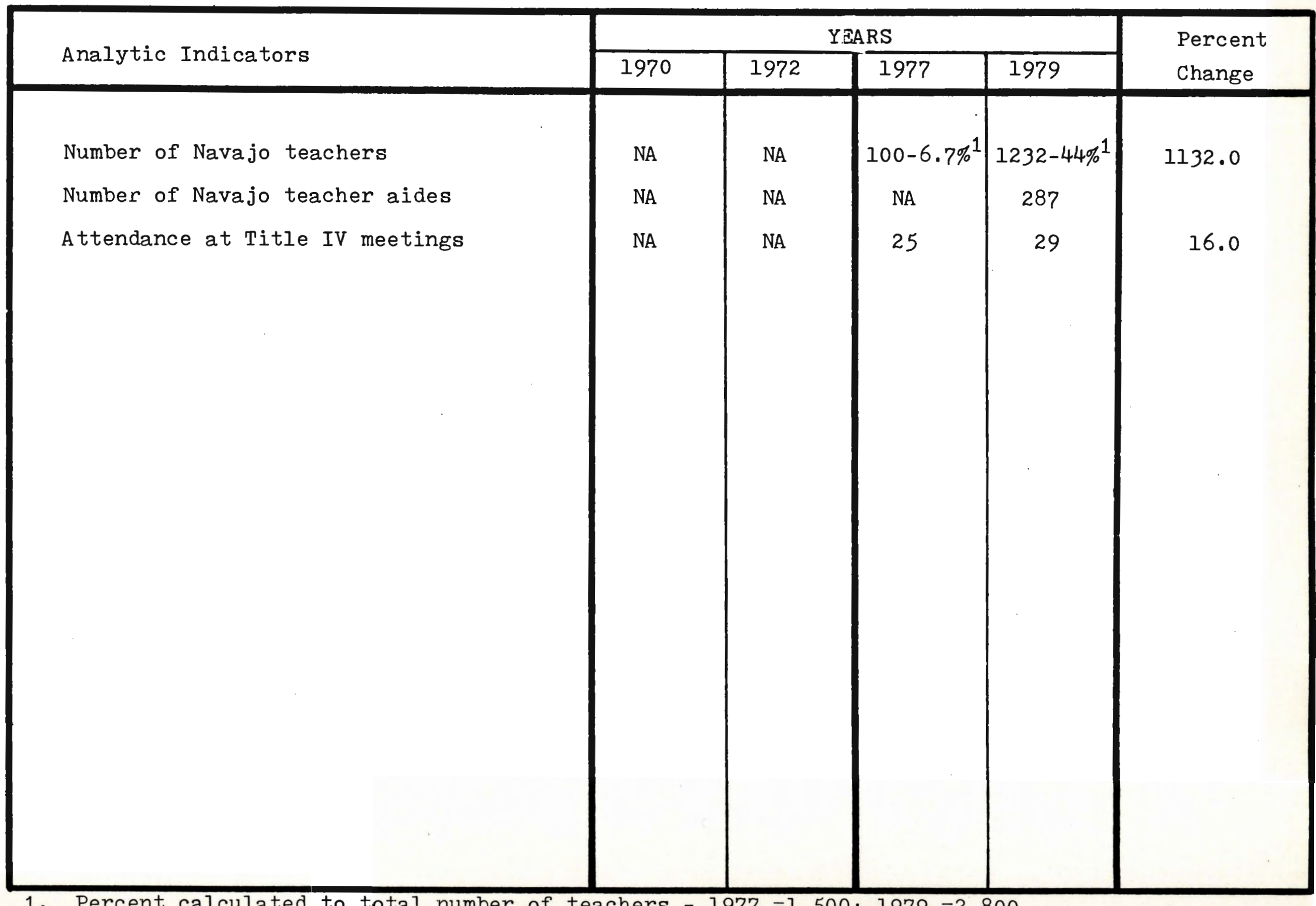

1. Percent calculated to total number of teachers $-1977=1,500 ; 1979=2,800$ 
operated by the Navajo tribe and the increasing public school enrollment. These changes are viewed as positive as they reflect the trend toward improvement in Indian education. The decline in beginners is significant because it shows that fewer students are starting their education with language problems that require a special class. In addition, the decline in BIA school enrollment is interpreted as a trend toward self-determination as the contract schools began operation during the decade. The contract schools' enrollment has increased by two percent from 862 in 1977 to 880 in 1980. Although enrollment figures were not available by grade in 1977, this overall gain is sign of the acceptance of these schools by the Navajo community. The four schools are filled to capacity and the high school (Shiprock Alternative School) was opened in 1979 to meet the large number of students on the waiting list. As of 1982, the Navajo Nation intends to contract with the BIA for 2 more schools (one elementary and one junior high) by fiscal year 1985 .

The indicator selected to measure the trend of selfdetermination in the school system was the existence of school boards and their overall functions. The contract schools have instituted school boards which include all Navajo members who have decision-making authority on the hiring of personnel, curriculum changes and the evaluations at the closings of the school year. In contrast, the BIA school boards only serve an advisory capacity. However, they have implemented the concept of self-determination 
by revising the boards' composition to include Navajo members in 1972. Although it was impossible to gather data on public school boards, it was revealed through a telephone conversation to the Navajo Board of Education that schools with large Indian enrollments (e.g.,Gallup-McKinley) have some Navajo members, but they never are in the majority. Other indicators which assess the trend toward selfdetermination are the increases in Navajo teachers during the decade. By 1979, 44 percent of all the teachers in the BIA and contract schools were of Navajo descent. (No data are available on public schools.) The indicator, teacher aides, could not be used to assess self-determination progress in schools since no data were available before 1979. However, a staff member from the Navajo Division of Education revealed that the Navajo aides in 1979 served different functions in each of the school systems. In the tribal contract schools, these aides taught workshops on Navajo arts and crafts and lent support service to teachers while in the BIA schools the main function of teacher aides was to translate from the Navajo to English language.

Attendance at Title IV meetings was the only indicator available to measure the participation level at public meetings. This indicator had only a slight increase from 1977 to 1979 (16 percent).

The indicator, community involvement in the school system, provided little information. The only positive trend which was verified by the Navajo Division of 
Education was the encouragement of the community to participate in the special cultural activities held at the tribal contract schools to celebrate traditional festivities of the Navajo. The involvement of the community at the BIA schools and the public system appear to be more or less restricted to membership on school committees or the school boards.

The attitude of parents, teachers and students was impossible to assess without a survey of the Navajo and the school systems. For this analysis, the only data available is a 1978 organization questionnaire administered by the Bureau of Indian Affairs. The results of this survey summarized the opinions of the Navajo on questions related to the operation of schools and comments and suggestions for change. Over 80 percent of those questioned generally supported the Bureau operated schools. The majority felt that the BIA's school policies are flexible and provide for expression of local wishes in the majority of school decisions within the BIA schools. The only changes recommended concern the provision of more information on organization and management to support the efforts of local Navajo school boards and the planning of the Navajo Division of Education. Enrollment figures appear to contradict this survey since BIA school enrollment has declined sharply during the 1970's.

In sum, analytic indicators generally show significant trends toward self-determination in the schools. 
More Navajo teachers are being hired, parental involvement is encouraged, contract schools are gaining enrollment and Navajo school boards with decision-making authority are emerging. The information not quantified does provide support to the commitment of the Navajo Division of Education to operating their schools under community control. Correlation of these indicators showing the stong role of self-determination in the contract school with an increasing enrollment is important for the final analysis.

\section{Ouput Descriptive Indicators}

These indicators continue to measure the educational delivery systems. The overall education level (4.1) and the percentage of the Navajo population with high school education ( 17 percent) in 1970 support the profile of the low quality of life experienced on the reservation.

School enrollment statistics from 1970 to 1979 show an increase in school attendance for all systems. However, the percentage of the school aged population enrolled in school declined by two percentage point in 1977 to ten percent. (The census of school aged population was not taken in 1979.)

other statistics verify an improvement in educational achievement; adult education enrollment increased from 1977 to 1979 with three percent more GED graduates in 1979 and college enrollment rose from 13 in 1979 to 1,919 in 1979. The breakdown by school systems of enrollment and 
TABLE XX

DATA COMPILATION

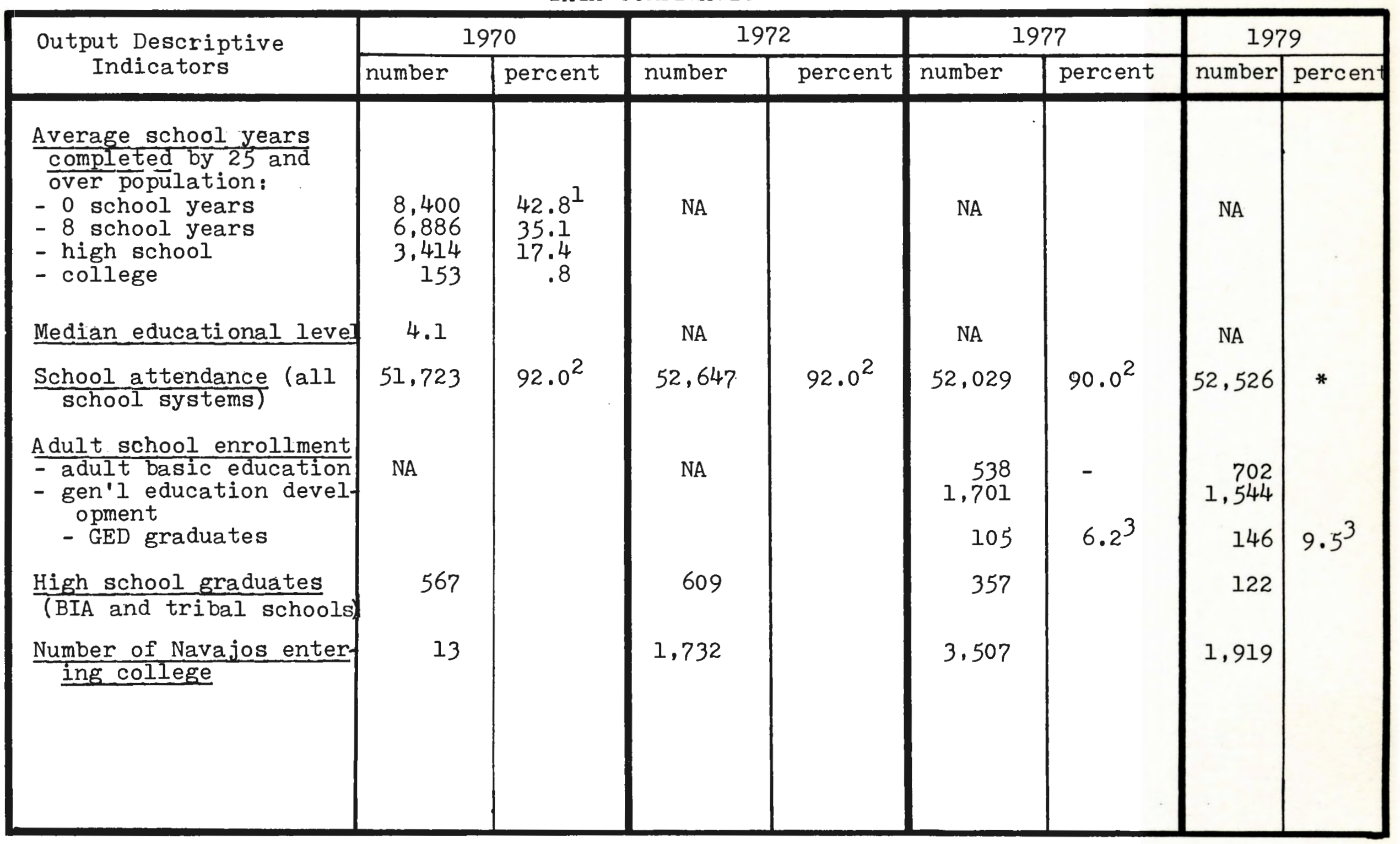

1. Percent calculated to the population 25 years and older $(1970=19,643)$

2. Percent calculated to $5-18$ population $(1970=56,797 ; 1972=57,144 ; 1977=57,691)$

3. Percent calculated to the total GED enrollment

* School census of 5-18 population not taken in 1979 
TABLE XX (cont.)

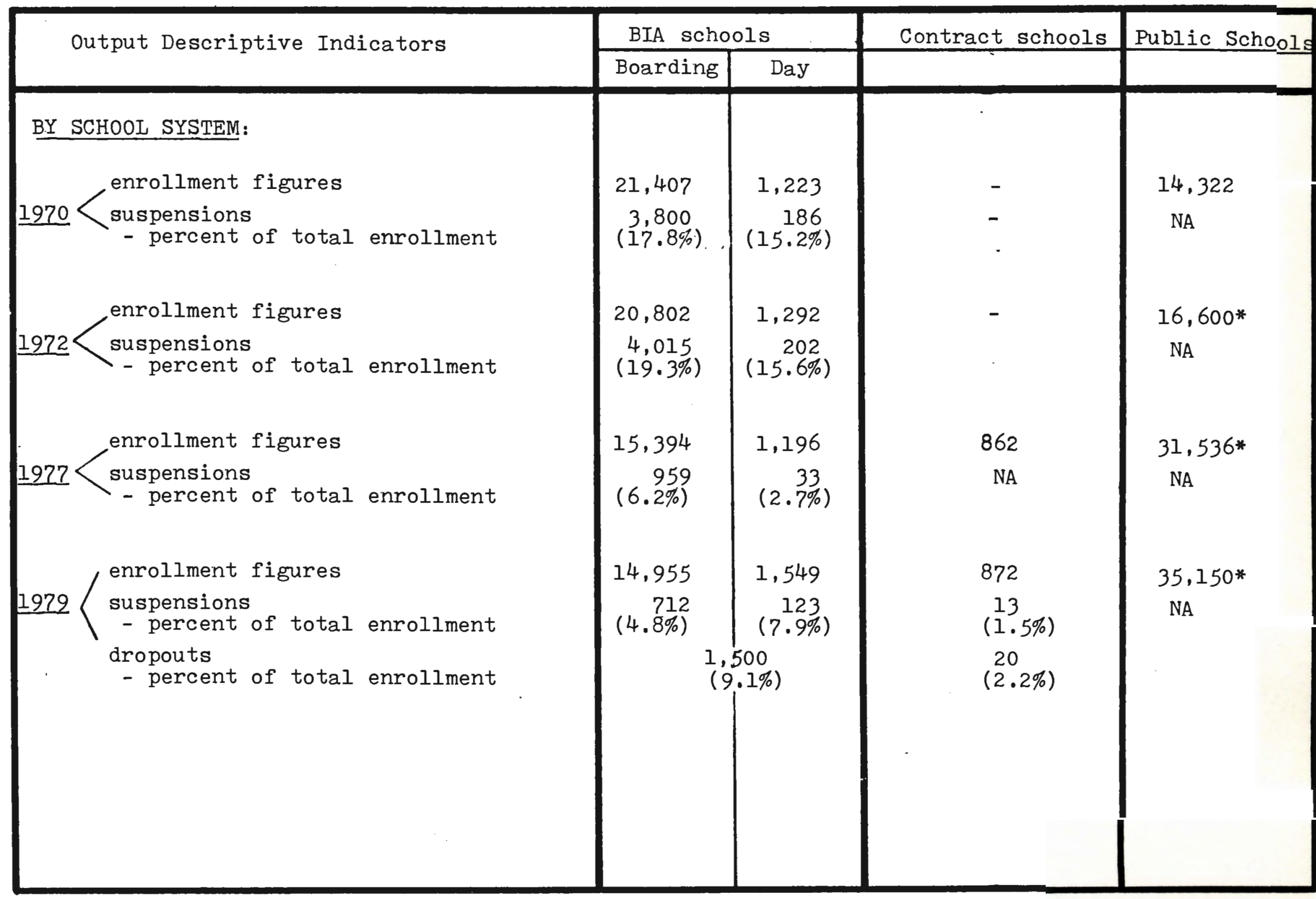

* public school figures represent Navajo students who receive Johnson-0'Malley funding. 
suspensions provides the most significant information on self-determination and its improvement of the educational process. The number of suspensions from 1970 to 1979 in the BIA boarding schools has declined from approximately 18 percent to five percent respectively. Day school figures generally show the same decline. When comparing BIA and contract school figures, the impact of selfdetermination is more significant. Suspensions in contract schools represent only one percent of total school enrollment in 1979 when compared with BIA boarding and day school figures (five and eight percent, respectively). This same trend is evident in the number of dropouts with contract schools losing only two percent of their total school enrollment in comparison to nine percent in BIA schools.

These indicators focus on the results of self-determination in school achievement and do show significant trends toward improvement with more Navajos staying in school and attending higher education institutions. The 1980 information on median educational level and average school years completed will provide a more thorough evaluation of the study.

\section{Side Effect Indicators}

Side effect indicators contribute to the overall profile of the Navajo Indians as a community which suffers from poor economic and social conditions. Statistics concerning employment show that approximately 65 percent 
TABLE XXI

DATA COMPILATION

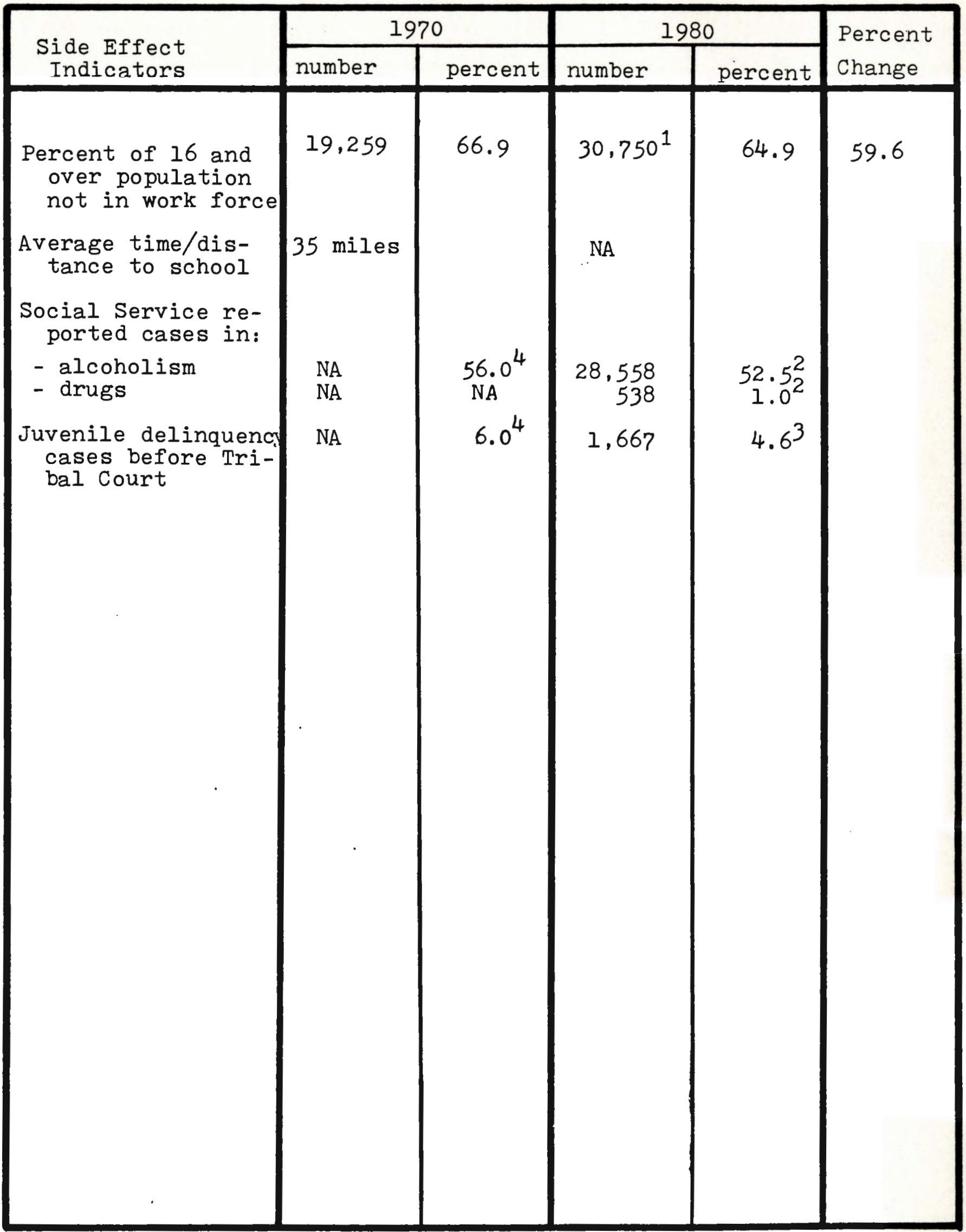

1. 1975 figure

2. Percent calculated to 18 and over population

3. Percent calculated to school-aged population (5-18)

4. No number figures are available from the BIA for 1970; percentages nnn notimntan af tatal nannintinn 
of the 16 and over population in both 1970 and 1975 were not members of the labor force. Many of the unemployed suffer from physical and emotional problems which restrict their labor pool potential.

Social or emotional problems continue to exist on the reservation with over 53 percent of the adult population reporting problems in alcohol and drugs in 1980.

In reference to the educational environment, indicators reveal indirect causes of the low educational achievement level of the Navajo. Bus routes for children attending day schools in 1970 averaged approximately 35 miles. Although 1980 figures are not available, no new schools or roads have been constructed. Thus, the average distance to school for day students is assumed to be approximately the same mileage figure. In addition, juvenile delinquency is reported to exist in approximately 5 percent of the school aged population. It should be noted that these figures are only those cases reported and the actual number of victims may be much higher.

In summary, the data collected for 1970 and 1980 in this category reveal some of the underlying causes of the low educational achievement of the Navajo. In addition, there is little evidence of improvement in these variables over time. The high alcoholism and juvenile delinquency cases and the number of persons not in the work force contribute to the lack of a supportive environment for education improvements for the Navajo children. The 
information suggests that the educational delivery system as it presently exists on the reservation is not meeting the needs of the population. These continuing social and economic problems can be interpreted as either a response to the low education achievement of the Navajo or a reaction to the breakdown of other social systems which are then causing the low educational achievement.

\section{Findings}

The indicators analyzed in this chapter for which data were available provide encsuraging information on the improvement of educational achievement through selfdetermination. The first question the research assesses is the existence of self-determination. The creation of the four tribally controlled schools, the development of the Navajo Tribal Education plan and the increasing role of the Indian community in changing policies and course offerings have all been quantified and measured over time in the study.

Educational achievement has also improved. The statistics from the Bureau of Indian Affairs show that more Indians are completing their education and going on to higher education programs. Self-determination has played a significant role in this achievement. Although each of the school systems has implemented to some degree the concept of self-determination, it appears that the contract schools have followed more intensively the dictates 
of self-determination and are achieving more positive results. Suspension and dropout figures are lower, enrollment is increasing and the four schools have long waiting lists of applicants.

However, some indicators, such as the continuing social problems of drugs, alcohol and juvenile delinquency and the high rate of unemployment revea] that improvement in educational achievement is not progressing to all levels of the Navajo population. It is believed that these trends verified for the study period will be responsible for the 1980 Census figures showing Indians still beneath the national norm in educational achievement. The improvement which has been experienced during the decade in education represents only gradual changes. The commitment to self-determination in areas such as input of the Navajo community in public and BIA schools needs to be more intensive if educational achievement is going to provide equal opportunities to the Tribe.

During the 1970's, the concept of self-determination was accepted and implemented to some degree by both the tribal and Federal governments. However, self-determination requires the necessary abilities to manage resources, which, in turn, depends on an efficient educational system that meets the changing needs of the Navajo population. A number of challenges must still be met; better information systems need to be developed with more statistics on public school systems in order to assess the success of changing policies, 
more adult education classes to reach that age group, more input of the Navajo community on school issues, and, most important, the Navajo need to strengthen their sense of community by developing community consensus on the issues. The discrepancy between statistics which show a decline in BIA school enrollment and the survey which reveals that 80 percent of the Navajo support the Bureau's school system verify the lack of consensus on tribal policy and issues. The Navajo Division of Education has acted on the Tribal Plan by implementing some of the stated goals and policies, but their effectiveness will be more powerful in their dealings with the state and Federal schools when they have made the policies of the Navajo Education Plan a national goal of the Navajo Nation.

The decade of the eighties is a critical period in the development and advancement of the Indian community. The analysis in this project supports the improvement of Indian education through self-determination, but its implementation was weakened by lack of funding and consensus on the approach of the different school systems to the directives of the Federal government. The government must affirm its commitment to self-determination in the 1980's by appropriating needed funding sources for the implementation of programs in public school systems and the Bureau of Indian Affairs' schools. A cooperative relationship between the three school systems and an increase in funding are the only solutions which will lead to Indian self-sufficiency in the years ahead. 


\section{Critique}

This critique focuses on two areas of concern: collection of indicators for the study and the development of a social system model to evaluate policy decisions.

The selection of indicators for this project is based on several key assumptions:

- The results of Nixon's policy statement and subsequent legislation can be quantified.

- The output indicators selected will accurately measure the changes in the educational delivery system.

- The other types of indicators identify causes of change to such an extent that the reason for the change can be stated.

The above assumptions are recognized and must be adopted if the findings can be accepted as a correct interpretation of the education process as it exists on the reservation.

A major problem with the indicators selected is the application of the method to the Navajo Indian reservation. The data sources on Indians are poor informational systems, subject to inconsistency in reports, high margin of error due to the collection methods of the BIA and the isolation and poor accessibility of the Navajo population. Reliance on statistics is difficult since the Bureau often administers the programs on which data are collected for reports on performance and attendance. Their statistical reports 
are often challenged by the Navajo tribe as being inaccurate.

The social indicator model is an excellent approach to organizing indicators since it requires the researcher to correctly identify types of indicators and represent the social process under investigation. In order to accomplish this identification competently, an understanding not only of the use of indicators is necessary, but of the process of a social system also. A social process model is a valid method to evaluate social policy since it requires a thorough knowledge of the interrelationships of all social processes in a society. 


\section{APPENDIX A}

President Nixon's Special Message

1970 


\section{Special Message to the Congress on Indian Aftairs July 8, 1970}

To the Congress of the United States:

The first Americans- the Indians-are the most deprived and most isolated minority group in our nation. On virtually every scale of measurement-employment, income, education, health - the condition of the Indian people ranks at the bottom.

This condition is the heritage of centuries of injustice. From the time of their first contact with European settlers, the American Indians have been oppressed and brutalized, deprived of their ancestral lands and denied the opportunity to control their own destiny. Even the Federal programs which are intended to meet their needs have frequently proven to be ineffective and demeaning.

But the story of the Indian in America is something more than the record of the white man's frequent aggression, broken agreements, intermittent remorse and prolonged failure. It is a record also of endurance, of survival, of adaptation and creativity in the face of overwhelming obstacles. It is a record of enormous contributions to this country-tn its art and culture, to its strength and spirit, to its sense of history and its sense of purpose.

It is long past time that the Indian policies of the Federal government began to recognize and build upon the capacities and insights of the Indian people. Both as a matter of justice and as a matter of enlightened social policy, we must begin to act on the basis of what the Indians themselves have long been telling us. The time has break decisively with the past and to con the conditions for a new era in which Indian future is determined by Indien and Indian decisions.

\section{Self.Determination Without Termination}

The first and most basic question the must be answered with respect to Indian policy concerns the historic and legal reth. tionship between the Federal governmen and Indian communities. In the pas, th relationship has oscillated between wo equally harsh and unacceptable extremes.

On the one hand, it has-at various times during previous Administrarions-been the stated policy objective of both the Executive and Legislative branches of the Federal gorernment eventually to terminate the trustece ship relationship between the Federal government and the Indian people. As recently as August of 1953, in House Concurrent Resolution 108, the Congress declared that termination was the long-range goal of its Indian policies. This would mean that Indian tribes would eventually lose any special standing they had under Federal law: the ux exempt status of their lands would be discontinued; Federal responsibility for their economic and social well-being would be repudiated; and the tribes themselves would be effectively dismantled. Tribal property would be divided among individual

members who would then be assimilated into the society at large.

This policy of forced termination is wrong, in my judgment, for a number of reasons. First, the premises on which it rests are wrong. Termination implies that the Federal government has taken on a trusteeship responsibility for Indian communities as an act of generosity toward a disadvantaged people and that it can therefore discontinue this responsibility on a unilateral basis whenever it sees fit. But the unique starus of Indian tribes does not rest on any premise such as this. The special relationship between Indians and the Federal government is the result instead of solemn obligations which have been entered into by the United States Government. Down through the years, through written treaties and through formal and informal agreements, our government has made specific commitments to the Indian people. For their part, the Indians have often surrendered claims to vast tracts of land and have accepted life on government reservations. In exchange, the government hus agreed to provide 
July $8 \quad$ Public Papers of the Presidents

community services such as health, education and public safety, services which would presumably allow Indian communities to enjoy a standard of living comparable to that of other Americans.

This goal, of course, has never been achieved. But the special relationship between the Indian tribes and the Federal government which arises from these agreements continucs to carry immense moral and legal force. To terminate this relationship would be no more appropriate than to terminate the citizenship rights of any other American.

The second reason for rejecting forced termination is that the practical results have been clearly harmful in the few instances in which termination actually has bcen tried. The removal of Federal trusteeship responsibility has produced considerable disorientation among the affected Indians and has left them unable to relate to a myriad of Federal, State and local assistance efforts. Their economic and social condition has of ten been worse after termination than it was before.

The third argument I would make against forced termination concerns the cffect it has had upon the overwhelming majority of tribes which still enjoy a special relationship with the Federal govcrmment. The very threat that this relationship may someday be ended has created a great deal of apprehension among Indian groups and this apprehension, in turn, has had a blighting effect on tribal progress. Any step that might result in greater social, economic or political autonomy is regarded with suspicion by many Indians who fear that it will only bring them closer to the day when the Federal government will disavow its responsibility and cut them adrift.

In short, the fear of one extreme policy, forced termination, has of ten worked to produce the opposite extreme: excessive dependence on the Federal government. In many cases this dependence is so great that the Indian community is almost entirely nun by outsiders who are responsible and responsive to Federal officials in Washington, D.C., rather than to the communities they are supposed to be serving. This is the second of the two harsh approaches which have long plagued our Indian policies. Of the Department of the Interior's programs directly serving Indians, for example, only 1.5 percent are presently under Indian control. Only 2.4 percent of HEW's Indian health programs are run by Indians. The result is a burgeoning Federal bureaucracy, programs which are far less effective than the ought to be, and an erosion of Indian initiative and morale.

I believe that both of these policy extremes are wrong. Federal termination errs in one direction, Federal paternalism errs in the other. Only by clearly rejecting both of these extremes can we achieve a policy which truly serves the best interests of the Indian people. Self-determination among the Indian people can and must be encouraged without the threat of eventual termination. In my view, in fact, that is the only way that self-determination can effectively be fostered.

This, then, must be the goal of any new national policy toward the Indian people: to strengthen the Indian's sense of autonomy without threatening his sense of community. We must assure the Indian that he can assume control of his own life without being separated involuntarily from the tribal group. And we must make it clear that Indians can become independent of Federal control without being cut off from Federal concern and 


\section{Richard Nixon, 1970 July 8 .}

Federal support. My specific recommendations to the Congress are designed to carry out this policy.

\section{Rejecting Termination}

Because termination is morally and legally unacceptable, because it produces bad practical results, and because the mere threat of termination tends to discourage greater self-sufficiency among Indian groups, I am asking the Congress to pass a new Concurrent Resolution which would expressly renounce, repudiate and repeal the termination policy as expressed in House Concurrent Resolution 108 of the 83 rd Congress. This resolution would explicitly affirm the integrity and right to continued existence of all Indian tribes and Alaska native governments, recognizing that cultural pluralism is a source of national strength. It would assure these groups that the United States Government would continue to carry out its treaty and trusteeship obligations to them as long as the groups themselves believed that such a policy was necessary or desirable. It would guarantee that whenever Indian groups decided to assume control or responsibility for government service programs, they could do so and still receive adequate Federal financial support. In short, such a resolution would reaffirm for the Legislative branch-as I hereby affirm for the Executive branch-that the historic relationship between the Federal government and the Indian communities cannot be abridged without the consent of the Indians.

\section{The Right to Control and Operate Federal Programs}

Even as we reject the goal of forced termination, so must we reject the suffocating pattern of paternalism. But how can we best do this? In the past, we have ofte: assumed that because the government is obliged to provide certain services $f \circ:$ Indians, it therefore must administe: those same services. And to get rid of Fecं. eral administration, by the same toke:. of ten meant getting rid of the whole Fec. eral program. But there is no necessa-: reason for this assumption. Federal su:port programs for non-Indian commur: ties-hospitals and schools are two reas. examples-are ordinarily administered $r$ : local authorities. There is no reason wi: Indian communities should be deprived $c$ : the privilege of self-determination mere: because they receive monetary suppo:from the Federal government. Nor shou: they lose Federal money because they :e. ject Federal control.

For years we have talked about encouraging Indians to exercise greater self-determination, but our progress has neve: been commensurate with our promises. Part of the reason for this situation has been the threat of termination. But ar:other reason is the fact that when a decision is made as to whether a Federa! program will be turned over to Indian administration, it is the Federal authorities and not the Indian people who finally make that decision.

This situation should be reversed. In my judgment, it should be up to the Indian tribe to determine whether it is willing and able to assume administrative responsibility for a service program which is presently administered by a Federal agency. To this end, I am proposing legislation which would empower a tribe or a group of tribes or any other Indian community to take over the control or operation of Federally-funded and administered programs in the Department of the Interior and the Department of Health, Ed- 
July $8 \quad$ Public Papers of the Presidents

ucation and Melfare whenever the triba' council or comparable community goveming group voted to do so.

Under this legislation, it would not be necessary for the Federal agency adminis tering the program to approve the transfer of responsibility. It is my hope and expectation that most such transfers of power would still take place consensually as a result of negotiations between the lacal community and the Federal government. But in those cases in which an impasse arises between the two parties, the final determination should rest with the Indian community.

Under the proposed legislation, Indian control of Indian programs would always be a wholly voluntary matter. It would be possible for an Indian group to select that program or that specified portion of a program that it wants to run without assuming responsibility for other components. The "right of retrocession" would also be guaranteed; this means that if the local community elected to administer a program and then later decided to give it back to the Federal government, it would always be able to do so.

Appropriate technical assistance to help local onganizations successfully operate these programs would be provided by the Federal government. No tribe would risk economic disadvantage from managing its own programs; under the proposed legislation, locally-administered programs would be funded on equal terms with similar services still administered by Federal authorities. The legislation I propose would include appropriate protections against any action which endangered the rights, the health, the safety or the welfare of individuals. It would also contain accountability proce- dures to guard against gross negligence or mismanagement of Federal funds.

This legislation would apply only to services which go directly from the Fed. eral government to the Indian community; those services which are channeled through State or local governments could still be turned over to Indian control by mutual consent. To run the activities for which they have assumed control, the Indian groups could employ local people or outside experts. If they chose to hire Federal employees who had formerly administered these projects, those employees would still enjoy the privileges of Federal employee benefit programs-under special legislation which will also be submitted to the Congress.

Legislation which guarantees the right of Indians to contract for the control or operation of Federal programs would directly channel more money into Indian communities, since Indians themselves would be administering programs and drawing salaries which now of ten go to non-Indian administrators. The potential for Indian control is significant, for we are talking about programs which annually spend over $\$ 400$ million in Federal funds. A policy which encourages Indian administration of these programs will help build greater pride and resourcefulness within the Indian community. At the same time, programs which are managed and operated by Indians are likely to be more effective in meeting Indian needs.

I speak with added confidence about these anticipated results because of the favorable experience of programs which have already been tumed over to Indian control. Under the auspices of the Office of Economic Opportunity, Indian communities now run more than 60 commu- 
Richard Nixon, $1970 \quad$ July: 8

nity action agencies which are located on Federal reservations. OEO is planning to spend some $\$ 57$ million in Fiscal Year 1971 through Indian-controlled grantees. For over four years, many OEO-funcled programs have operated under the control of local Indian organizations and the results have been most heartening.

Two Indian tribes-the Salt River Tribe and the Zuni Tribe-have recently extended this principle of local control to virtually all of the programs which the Bureau of Indian Affairs has traditionally administered for them. Many Federal officials, including the Agency Superintendent, have been replaced by elected tribal officers or tribal employees. The time has now come to build on these experiences and to extend local Indian control-at a rate and to the degree that the Indians themselves establish.

\section{Restoring the Sacred Lands Near Blue Lake}

No government policy toward Indians can be fully effective unless there is a relationship of trust and confidence between the Federal government and the Indian people. Such a relationship cannot be completed overnight; it is inevitably the product of a long series of words and actions. But we can contribute significantly to such a relationship by responding to just grievances which are especially im: portant to the Indian people.

One such grievance concerns the sacred Indian lands at and near Blue Lake in New Mexico. From the fourteenth century, the Taos Pueblo Indians used these areas for religious and tribal purposes. In 1906, however, the Linited States Government appropriated these lands for the creation of a national forest. According to a recent determination of the Indian Claims Commission, the government "took said lands from petitioner without compensation."

For 64 years, the Taos Pueblo has been trying to regain possession of this sacred lake and watershed area in order to preserve it in its natural condition and limit its non-Indian use. The Taos Indians consider such action essential to the protection and expression of their religious faith.

The restoration of the Blue Lake lands to the Taos Pueblo Indians is an issue of unique and critical importance to Indians throughout the country. I therefore take this opportunity wholeheartedly to endorse legislation which would restore 48 ,ooo acres of sacred land to the Taos Pueblo people, with the statutory promise that they would be able to use these lands for traditional purposes and that except for such uses the lands would remain forever wild.

With the addition of some perfecting amendments, legislation now pending in the Congress would properly achieve this goal. That legislation (H.R. 471) should promptly be amended and enacted. Such action would stand as an important symbol of this goremment's responsiveness to the just grievances of the American Indians.

\section{Indian Education}

One of the saddest aspects of Indian life in the United States is the low quality of Indian education. Drop-out rates for Indians are twice the national average and the average educational level for all Indians under Federal supervision is less than six school years. Again, at least a part of the problem stems from the fact that the Federal government is trying to 


\section{July $8 \quad$ Public Papers of the Presidents}

do for Indians what many Indians could do better for themsclves.

The Federal government now has responsibility for some 221,000 Indian children of school age. While over 50,000 of these children attend schools which are operated directly by the Bureau of Indian Affairs, only 750 Indian children are enrolled in schools where the responsibility for education has been contracted by the BIA to Indian school boards. Fortunately, this condition is beginning to change. The Ramah Navajo Community of New Mexico and the Rough Rock and Black Wiater Schools in Arizona are notable examples of schools which have recently been brought under local Indian control. Several other communities are now negotiating for similar arrangements.

Consistent with our policy that the Indian community should have the right to take over the control and operation of federally funded programs, we believe every Indian community wishing to do so should be able to control its own Indian schools. This control would be exercised by school boards selected by Indians and functioning much like other school boards throughout the nation. To assure that this goal is achieved, I am asking the Vice President, acting in his role as Chairman of the National Council on Indian Opportunity, ${ }^{1}$ to establish a Special Education Subcommittee of that Council. The members of that Subcommittee should be Indian educators who are selected by the

\footnotetext{
'Executive Order 11551, dated August 11, 1970, provided for additional Indian members on the National Council on Indian Opportunity. A White House release dated August 31, announcing the appointment of eight new members to the Council, is printed in the Weekly Compilation of Presidential Documents (vol. 6, p. 1132).
}

Council's Indian nembers. The Subcommittee will provide technical assistance to Indian communities wishing to establish school boards, will conduct a nationwide review of the educational status of all Indian school children in whatever schools they may be attending, and will evaluate and report annually on the status of Indian education, including the extent of local control. This Subcommittee will act as a transitional mechanism; its objective should not be self-perpetuation but the actual transfer of Indian education to Indian communities.

We must also take specific action to benefit Indian children in public schools. Some 14I,000 Indian children presently attend general public schools near their bomes. Fifty-two thousand of these are absorbed by local school districts without special Federal aid. But 89,00 Indian children attend public schoois in such high concentrations that the State or local school districts involved are eligible for special Federal assistance under the Johnson-O'Malley Act. ${ }^{2}$ In Fiscal Year 197I, the Johnson-O'Malley program will be funded at a level of some $\$ 20$ million.

This Johnson-O'Malley money is designed to help Indian students, but since funds go directly to the school districts, the Indians have little if any influence over the way in which the money is spent. I therefore propose that the Congress amend the Johnson-O'Malley Act so as to authorize the Secretary of the Interior to channel funds under this act directly to Indian tribes and communities. Such a proxision would give Indians the ability to help shape the schools which their chil-

\footnotetext{
Public Law No. 638, June 4, 1935 ' 49 Stat.

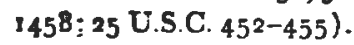


Richurd Nixon, $197^{\circ} \quad$ July 8

dren attend and, in some instances, to set up new school systems of their own. At the same time, I am directing the Secretary of the Interior to make every effort to ensure that Jolinson-O Malley funds which are presently directed to public school districts are actually spent to improve the education of Indian clildren in these districts.

\section{Economic Deiclopment Legislation}

Economic deprivation is among the most serious of Indian problens. L'nemployment among Indians is ten times the national average: the unemployment rate runs as high as 80 percent on some of the poorest rcservations. Eiglity percent of reservation Indians lave an income which falls below the porerty line; the average annual income for such families is only $\$ 1.500$. As I said in Scptember of 1968 , it is critically important that the Federal government support and encouragre efforts which help Indians devclop their own economic infrastructure. To that end, I am proposing the "Inclian Financing Act of 1970."

This act would do two things:

I. It would broaden the existing Revolving Loan Fund, which loans money for Indian economic development projects. I am asking that the authorization for this fund be increased from approximately $\$ 25$ million to $\$ 75$ million.

2. It would provide additional incentives in the form of loan guarantes, loan insurance and interest subsidies to encourage pricate lenders to loan more money for Indian economic projects. $\Lambda \mathrm{n}$ aggregate amount of $\$ 200$ million would be authorized for loan guarantee and loan insurance purposes.
I also urge that legislation be enacted which would permit any tribe which chooses to do so to enter into leases of its land for up to 99 years. Indian people now own over 50 million acres of land that are held in trust by the Federal government. In order to competc in attracting investment capital for commercial, industrial and recreational development of these lands, it is essential that the tribes be able to offer long-term leases. Long-term leasing is preferable to selling such property since it enables tribes to preserve the trust ownership of their reservation homelands. But existing law limits the length of time for which many tribes can enter into such leases. Moreover, when long-term leasing is allowed, it has been granted by Congress on a case-by-case basis, a policy which again reflects a deep-rooted pattern of paternalism. The twenty reservations which have already been given authority for long-term leasing have realized important benefits from that privilege and this opportunity should now be extended to all Indian tribes.

Economic planning is another att.. where our efforts can be significantly inproved. The comprehensive economic development plans that have been created by both the Pima-Maricopa and the Zuni Tribes provide outstanding examples of interagency cooperation in fostering Indian economic growth. The Zuni Plan, for example, extends for at least five years and involves a total of $\$ \overline{55}$ million from the Departments of Interior, Housing and L'rban Development, and Health. Education and Welfare and from the Office of Economic Opportunity and the Economic Development Administration. I am directing the Secretary of the Interior 


\section{July $8 \quad$ Public Papers of the Presidents}

to play an active role in coordinating additional projects of this kind.

\section{More Money for Indian Health}

Despite significant improvements in the past decade and a half, the health of Indian people still lags 20 to 25 years behind that of the general population. The average age at death among Indians is 44 years, about one-third less than the national average. Infant mortality is nearly $50 \%$ higher for Indians and Alaska natives than for the population at large: the tuberculosis rate is eight times as high and the suicide rate is twice that of the general population. Many infectious diseases such as trachoma and dysentery that have all but disappeared among other Americans continue to afflict the Indian people.

This Administration is determined that the health status of the first Americans will be improved. In order to initiate expanded efforts in this area, I will request the allocation of an additional \$1 o million for Indian health programs for the current fiscal year. This strengthened Federal effort will enable us to address ourselves more effectively to those health problems which are particularly important to the Indian community. We understand, for example, that areas of greatest concern to Indians include the prevention and control of alcoholism, the promotion of mental health and the control of middleear disease. We hope that the ravages of middle-ear disease-a particularly acute disease among Indians-can be brought under control within five years.

These and other Indian health programs will be most effective if more Indians are involved in running them. Yetalmost unbelievably-we are presently able to identify in this country only 30 physicians and fewer than 400 nurses of Indian descent. To meet this situation, we will expand our efforts to train Indians for health careers.

\section{Helping Urban Indians}

Our new census will probably show that a larger proportion of America's Indians are living off the reservation than ever before in our history. Some authorities even estimate that more Indians are living in cities and towns than are remaining on the resenation. Of those American Indians who are now dwelling in urban areas, approximately three-fourths are living in poverty.

The Bureau of Indian Affairs is organized to serve the 462,000 reservation Indians. The BIA's responsibility does not extend to Indians who have left the reservation, but this point is not always clearly understood. As a result of this misconception, Indians living in urban areas have of ten lost out on the opportunity to participate in other programs designed for disadvantaged groups. As a first step toward belping the urban Indians, I am instructing appropriate officials to do all they can to ensure that this misunderstanding is corrected.

But misunderstandings are not the most important problem confronting urban Indians The biggest barrier faced by those Federal, State and local programs which are trying to serve urban Indians is the difficulty of locating and identifying them. Lost in the anonymity of the city, often curt of from family and friends, many urban Indians are slow to establish new community ties. Many drift from neighborhood to neighborhood; many shuttle back and forth between reserva- 


\section{Richard Nixon, $1970 \quad$ July 8}

tions and urban areas. Language and cultural differences compound these problems. As a result, Federal, State and local programs which are designed to help such persons often miss this most deprived and least understood segment of the urban poverty population.

This Administration is already taking steps which will help remedy this situation. In a joint effort, the Office of Economic Opportunity and the Department of Health, Education and Welfare will expand support to a total of seven urban Indian centers in major cities which will act as links between existing Federal, State and local service programs and the urban Indians. The Departments of Labor, Housing and Urban Development and Commerce have pledged to cooperate with such experimental urban centers and the Bureau of Indian Affairs has expressed its willingness to contract with these centers for the performance of relocation services which assist reservation Indians in their transition to urban employment.

These efforts represent an important beginning in recognizing and alleviating the severe problems faced by urban Indians. We hope to learn a great deal from these projects and to expand our efforts as rapidly as possible. I am directing the Office of Economic Opportunity to lead these efforts.

\section{Indian Trust Counsel Authority}

The United States Government acts as a legal trustee for the land and water rights of American Indians. These rights are of ten of critical economic importance to the Indian people; frequently they are also the subject of extensive legal dispute. In many of these legal confrontations, the
Federal government is faced with an inherent conflict of interest. The Secretary of the Interior and the Attorney General must at the same time advance both the national interest in the use of land and water rights and the private interests of Indians in land which the government holds as trustee.

Every trustee has a legal obligation to adrance the interests of the beneficiaries of the trust without reservation and with the highest degree of diligence and skill. Under present conditions, it is often difficult for the Department of the Interior and the Department of Justice to fulfill this obligation. No self-respecting law firm would ever allow itself to represent two opposing clients in one dispute; yet the Federal government has frequently found itself in precisely that position. There is considerable evidence that the Indians are the losers when such situations arise. More than that, the credibility of the Federal government is damaged whenever it appears that such a conflict of interest exists.

In order to correct this situation, I am calling on the Congress to establish an Indian Trust Counsel Authority to assure independent legal representation for the Indians' natural resource rights. This Authority would be governed by a threeman board of directors, appointed by the President with the advice and consent of the Senate. At least two of the board members would be Indian. The chief legal officer of the Authority would be designated as the Indian Trust Counsel.

The Indian Trust Counsel Authority would be independent of the Departments of the Interior and Justice and would be expressly empowered to bring suit in the name of the United States in its trustee capacit!. The Linited States would waive 


\section{July 8 Public Papers of the Presidents}

its sovereign irnmunity from suit in connection with litigation involving the Authority.

9. Assistant Secretary for Indien and Territorial Affairs

To help guide the implementation of a new national policy concerning American Indians, I am recommending to the Congress the establishment of a new position in the Department of the InteriorAssistant Secretary for Indian and Territorial Affairs. At present, the Commissioner of Indian Affairs reports to the Secretary of the. Interior through the Assistant Secretary for Public Land Managcment-an officer who has many responsibilities in the natural resources area which compete with his concern for Indians. A new Assistant Secretary for Indian and Territorial Affairs would have only one concern-the Indian and territorial peoples, their land, and their progress and well-being. Secretary Hickel and I both believe this new position represents an elevation of Indian affairs to their proper role within the Department of the Interior and we urge Congress to act favorably on this proposal.

\section{Continuing Programs}

Many of the new programs which are outlined in this message have grown out of this Administration's experience with other Indian projects that have been initiated or expanded during the last 17 months.

The Office of Economic Opportunity has been particularly active in the development of new and experimental efforts. OEO's Fiscal Year 1971 budget request for Indian-related activities is up 18 percent from 1969 spending. In the last year alonc-to mention just two examplesOEO doubled its funds for Indian crom nomic development and tripled its expenditures for alcoholism and recover. programs. In areas such as housing and home improvement, health carc, emergency fond, legal services and education, OEO prograns have been significantiv. expanded. As I said in my recent speech on the economy, I hope that the Congress will support this valuable work by appropriating the full amount requested for the Economic Opportunity Act.

The Bureau of Indian Affairs has already begun to implement our policy of contracting with local Indians for the operation of government prograuns. As I have noted, the Salt River Tribe and the Zuni Tribe have taken over the bulk of Federal services; other projects rangin? from job training centers to high school counseling programs have been contracted out to Indian groups on an individual basis in many areas of the country.

Economic development has also been stepped up. Of 195 commercial and industrial enterprises which have been established in Indian areas with BIA assistance, 7I have come into operation within the last two years. These enterprises provide jobs for more than 6,000 Indians and are expected to employ substantially more when full capacity is reached. A number of these businesses are now owned by Indians and many others are managed by them. To further increase individual Indian ouncrship, the BIA has this month initiated the Indian Business Development Fund which provides equity capital to Indians who go into business in reservation areas.

Since late 1967, the Economic Derelopment Administration has approved ap- 
proximately $\$ 80$ million in projects on Indian reservations, including nearly $\$ 60$ million in public works projects. The impact of such activities can be tremendous; on the Gila River Reservation in Arizona, for example, economic development projects over the last three years have helped to lower the unemployment rate from 56 to 18 percent, increase the median family income by $15^{\circ}$ percent and cut the welfare rate by 50 percent.

There has been additional progress on many other fronts since January of 1969. New "Indian Desks" have been created in each of the human resource departments of the Federal government to help coordinate and accelerate Indian programs. We have supported an increase in funding of $\$_{4}$ million for the Navajo Irrigation Project. Housing efforts have picked up substantially; a new Indian Police Acadeny has been set up; Indian education efforts have been expanded--including an increase of $\$ 8_{4} 8,000$ in scholarships for Indian college students and the establishment of the Navajo Cormunity College, the first college in America planned, developed and operated by and for Indians. Altogether, obligational authority for Indian programs run by the Federal Government has increased from a little over $\$ 598$ million in Fiscal Year 1970 to almost $\$ 626$ million in Fiscal Year 1971 .

Finally, I would mention the impact on the Indian population of the series of welfare reform proposals I have sent to the Congress. Because of the high rate of unemployment and underemployment among Indians, there is probably no other group in the country that would be helped as directly and as substantially by programs such as the new Family Assistance Plan and the proposed Family Health Insurance Plan. It is estimated, for example, that more than half of all Indian families would be eligible for Family Assistance benefits and the enactment of this legislation is therefore of critical importance to the American Indian.

This Administration has broken a good deal of new ground with respect to Indian problems in the last 17 months. We have leamed namy things and as a result we have been able to formulate a new approach to Indian affairs. Throughout this entire process, we have regularly consulted the opinions of the Indian people and their views have played a major role in the formulation of Federal policy.

As we move ahead in this important work, it is essential that the Indian people continue to lead the way by participating in policy development to the greatest possible degree. In order to facilitate such participation, I am asking the Indian members of the National Council on Indian Opportunity to sponsor field hearings throughout the nation in order to establish a continuing dialogue between the Executive branch of government and the Indian population of our country. I have asked the Vice President to see that the first round of field hearings are completed before October.

The recommendations of this Administration represent an historic step forward in Indian policy. We are proposing to break sharply with past approaches to Indian problems. In place of a long series of piecemeal reforms, we suggest a new and coherent strategy. In place of policies which simply call for more spending, we suggest policies which call for wiser spend. ing. In place of policies which oscillate between the deadly extremes of forced termination and constant paternalism, we 
[213] July 8 Public Papers of the Presidents

suggest a policy in which the Federal government and the Indian community play complementary roles.

But most importantly, we have turned from the question of whether the Federal government has a responsibility to Indians to the question of how that responsibility can best be fulfilled. We have concluded that the Indians will get better prograns and that public monics will be more effectively expended if the people who are most affected by these programs are responsible for operating them.

The Indians of America need Federal assistance-this much has long becn clear. What has not always been clear, however, is that the Federal government needs
Indian energies and Indian leacle: its assistance is to be effective in i:. ing the conditions of Indian life. 1 : new and balanced relationship, $\mid x \cdot$. the United States government :1..: . first Americans that is at the 'ie.nt. approach to Indian problems. Al..: is why we now approach these 1 ". . with new confidence that they wil. cessfully be overcome.

RIGHAR, . N $:$ :

The White House

July 8, 1970 


\section{APPENDIX B}

Indian Self-Determination and Education Assistance Act 1975 
8460 . Congreational declaration of policy

(a) The Congress hereby recognizes the obllgation of the United States to respond to the strong expresation of the Indian people for selfdetermination by assuring maximum Indian particlpation in the direction of educational as well as other Federal services to Indian commu. nitles 80 as to render such services more respon. sive to the needs and desires of those communlties.

(b) The Congreas declares its commitment to the maintenance of the Federal Government's unique and continuing relationshlp with and responsibility to the Indian people through the establishment of a meaningful Indian self-determination policy which will permit an orderly transition from Federal domination of programs for and services to Indians to effectlve and meaningful particlpation by the Indian people in the planning, conduct, and administration of those programs and services.

(c) The Congress declares that a major national goal of the United States is to provide the quantity and quality of educatlonal services and opportunities whlch will permit Indian chlldren to compete and excel in the life areas of their cholce, and to achleve the measure of self-determination essential to thelr soclal and economic well-belng.

(Pub. L. 03-638, 8 3, Jan. 4, 1976, 88 Stat. 2203.)

\section{Codincation}

(2) the Indian people will never surrender their desire to control thelr relationships both among themselves and with non-Indian covernments, organizatlons, and persons.

(b) The Congress further flnds that-

(1) true self-determination In any society of people is dependent upon an educational process which will Insure the development of qualified people to fulfill meaningful leader. ship roles;

(2) the. Federal responslbllity for and assistance to education of Indian chlldren has not effected the desired level of educational chlevement or created the diverse opportunilles and personal satisfaction which education an and should provide; and

(3) parental and community control of the educational process is of cruclal Importance to the Indian people.

Pub. L 93-638, 8, Jan. 4, 1975, 88 Stat. 2203.)

\section{Codrencation}

This rectlon was not enacted as part of title I of Pub. i H-638, which comprises this subchapter.

\section{Bront TrTu}

Lection 1 of Pub. Is 93-038 provided: "That this Act lmettin rectlons 132460 to 460n, 455, 486, 457, and 410458 of this title and section $2004 \mathrm{~b}$ of Title 12 . me Public Fealth and Welfare, amending section Hil of Title B. Government Organization and Em. wrees, section 1782 of Title 12 , and section 456 of mik 30, Appendix, War and Natlonal Deferse, and ennod provlsions eet out as notes under sectlons $480 f$. 4. and 457 of this titlel may be cited as the 'Indlan wi.Determination and Education Assistance Act'."

Eetion 101 of Pub. L. 93-638 provided that: "Thls nut imeaning title I of Pub. L. 93-038 which enacted ction 450 to $450 \mathrm{n}$ of this title and section $2004 \mathrm{~b}$ of ine 12. The Public Health and Welfare, and amend- ection 3371 of Title $B$, covernment Organization 4 Enployees, section $\mathbf{1 7 6 2}$ of Title 12, and section 4 of Tttle 80, Appendix, War and Natlonal Defense1 as be elted is the 'Indian gelf-Determination Act'."

This section was not enacted as part of title I of Pub. L. 93-638, which comprises this subchapter

\section{450b. Definitions}

For the purposes of this Act, the term-

(a) "Indian" means a person who is a member of an Indian tribe:

(b) "Indian trlbe" means any Indian tribe, band, nation, or other organized group or communlty, Including any Alaska Native village or regional or village corporation as defined in or established pursuant to the Alaska Native Clalms Settlement Act [43 U.S.C. 1601 et sea.] which is recosnized as eligible for the special programs and services provided by the United States to Indians because of their status as Indlans:

(c) "Iribal organization" means the recognized governing body of any Indian tribe; any legally established organization of Indians which is controlled, sanctioned, or chartered by such governing body or which is democratIcally elected by the adult members of the Indian community to be served by such organization and which includes the maximum participation of Indians in all phases of its activities: Provided, That in any case where a contract is let or grant made to an organiza. tion to perform services benefitting more than one Indian tribe, the approval of each such Indian tribe shall be a prerequisite to the letting or making of such contract or grant:

(d) "Becretary", unless otherwlse designated, means the Secretary of the Interlor:

(f) "State education agency" means the state board of education or other agency or (e). In origlnal. Bection was enacted without a par. 
officer primarlly responsible for supervision by the State of public elementary and second. ary schools, or, If there is no such officer or agency, an officer or agency designated by the Governor or by State law.

(Pub. L. 93-638, 84, Jan. 4, 1975, 88 Stat. 2204.)

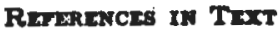

This Act, referred to in text, is the Indian Belf-Determination and Education Assistance Act, which is Pub. L. 03-638, Jan. 4, 1975, 88 Stat. 2203. For complete classiffication of this Act to the Code, see Bhort Title note set out under section $\mathbf{4 6 0}$ of this title and Tables volume.

The Alaska Native Claims Bettlement Act, referred to in text, is Pub. L. 82-203. Dec. 18, 1971, 85 8tat. 688, as amended, whlch is classifled generally to chapter 33 (8 1601 et seq.) of Title 43. Public Iands. For complete classification of this Act to the Code, see Short Title note set out under section 1601 of Title 43, and Tables volume.

\section{Codrication}

This soction was not enacted as part of title I of Pub. L. 93-638, which comprises this subchapter.

\section{SEction RETrRed to IM OTHER SLCTION8}

This section is referred to In title $B$ section 3371 .

$840 c$. Reporting and audit requirements for reciplentu of Federal financial assintance

(a) Maintenance of recorda

Bach recipient of Federal IInanclal assistance from the Secretary of Interlor or the Secretary of Health. Education, and Welfare, under this Act, shall keep such records as the approprlate Secretary shall prescribe, Including records which fully disclose the amount and disposition by such reciplent of the proceeds of such assistance, the cost of the project or undertaking in connection with which such assistance is given or used, the amount of that portion of the cost of the project or undertaking supplied by other sources, and such other records as will facllitate an effectlve audit.

(b) Access to books, documents, papers, and records for audlt and examination by Comptroller Gener. al, etc.

The Comptroller Ceneral and the appropriate Becretary, or any of their duly authorized representatives, shall, untll the expiration of three yeurs after completion of the project or undertaking referred to in the preceding sub. section of this section, have access (for the pur. pose of sudit and examination) to any books, documents, papers, and records of such recipients which in the opinion of the Comptroller General or the Appropriate Becretary may be related or pertinent to the srants, contracts, subcontracts, subgrants, or other arrangements referred to in the preceding subsection.

(c) Avallabillty by rectplent of required reports and information to Indian Peopie served or repre. sented

Each reciplent of Federal financlal satstance referred to in subsection $(a)$ of this section shall make such reports and information avallable to the Indian people served or represented by such reciplent as and in a manner determined to be adequate by the appropriate Becretary. (d) Repayment to Treasury by recipient of unnm ed or unused funds

Any funds paid to a financlal asslstanxe " clplent referred to in subsection (8) of thu tion and not expended or used for the purnam for which pald shall be repaid to the Trrusil of the United States.

(Pub. L. 93-638, \& 5, Jan. 4, 1975, 88 Stal. Jah

Rerantaxces in Thx

This Act, referred to in subsec. (a), is the tration Belf-Determination and Educstion Aesistaner which is Pub. It 93-638. Jan. 4, 1875; B8 Stal 230) T.o complete classiffication of this Act to the Cod Short Title note set out under section $\mathbf{4 5 0}$ of iris in. and Tables volume.

\section{Codipicatios}

This section was not enacted as part of tille I of ma L. 93-368, which comprises this subchapter.

8 450d. Criminal activities Involving sranth, rooum etc.; penalties

Whoever, being an offlcer, director, urmi ir employee of, or connected in any capacit os: any reclpient of a contract, subcontract. in." or subgrant pursuant to this Act or sections al: to 467 of this title, embezales, willfully ic my plies, steals, or obtains by fraud eny of tin money, funds assets, or property which arr $t$. subject of such a grant, subgrant, contract ip subcontract, shall be fined not more tha: $\$ 10,000$ or imprisoned for not more than in.. years, or both, but if the amount $80 \mathrm{cmb}$ misapplied, stolen, or obtained by irnud dim not exceed $\$ 100$, he shall be flned nol w., than $\$ 1,000$ or imprisoned not more thui a.e. year, or both.

(Pub. L: 93-638, 8, Jan. 4, 1975, 88 Scal zam

Rurencuces in Twxt

This Act, referred to in text, is the Indsen firs in termination and Education Assistance ACL whe Pub. L 93-638, Jan. 4, 1975, 88 Stal 2203. nam plete clasalfication of this Act to the Codp, ans, Title note set out under section $\mathbf{4 5 0}$ of thin ut: Tables volume.

\section{Copimcation}

This section was not enacted as part of tllte I of ma L. 93-638, whioh comprises this subchapler.

860 . Wage and labor standards and prefermen quirements for contracts or manto

(a) All laborers and mechanics emplorod is contractors or subcontractors in the carvene tion, alteration, or repalr, Including panur decorating of buildings or other faclilim in connection with contracts or srants enierm into pursuant to this Act, shall be pajd sivm at not less than those prevalling on simile struction in the locality, as determined by tu. Secretary of Labor in accordance with the Davis.Becon Act of March 3, 1031 (4) des 1494), as amended [40 U.S.C. 276a et req.1. WHA respect to construction, alteration, of work to which the Act of March 3, 1921 w wps cable under the terms of this section. the sext. tary of Labor shall have the authonty us functions set forth in Reorganization hw Numbered 14, of 1080, and section 27ce of erm 40. 
(b) Any contract, subcontract, grant, or submant pursuant to this Aot, sections 452 to $\mathbf{4 5 7}$ of this title, or any other Act authorizing Fedend contracts with or erants to Indian organiations or for the benefit of Indians, shall require that to the esreateat extent fersible-

(1) preferences and opportunities for training and employment in connectlon with the dminiatration of such contracts or grants shall be given to Indlans; and

(2) preference in the award of subcontracts and subgrants in connection with the administration of such contracts or grants shall be Given to Indian orcanizations and to Indianowned economic enterprises as defined in section 1462 of this title.

(Pub. L. 83-698, 8 7, Jan. 4, 1976, 88 Btat. 2205.)

\section{Rarmuras in Thx}

This Act, referred to in text, is the Indian Belf-Do. termination and Educatlon Avilstance Act, which is Pub. L. 98-638, Jan. 4, 1976, 88 gtat. 2203. For com. plete clasalfication of this Act to the Code, wee short Tille note set out under section $\mathbf{4 6 0}$ of this title and Tables volume.

The Davls Becon Act of Murch 3, 1931 (40 Btat. 1494), as amended, referred to In subsec. (a), is act Mar. 3, 1831, ch. 411,40 Btat. 1494, as amended, which t clessfled generally to sections 276a to 276a-5 of Title 40, Public Bulldings, Property, and Works. For complete classification of this Act to the Code, see Short Title note set out under section 276a of Title 40 and Tables volume.

The Act of March 3, 1921, referred to In subsec. (a), probubly means the act of March 3, 1931, ch. 111,46 Slat. 1494, as amended, known as the Davls Bacon Act. See note above.

Reorganization Plan Numbered 14 of 1960 , referred 10 in subsec. (a), is set out in the Appendix to Title 5, Covernment Ortranization and Bmployees.

\section{Codrincarton}

This section was not enacted as part of title I of Pub. L. 93-638, which comprises this subchapter.

\$ 450f. Contract by Secretary of the Interior with tribal organizations

(a) Requeat by tribe for contract by Secretary to plan, conduet and adminiater education, etc., programs; refusal of request

The Becretary of the Interior is directed, upon the request of any Indian tribe, to enter Into a contract or contracts with any tribal orsanization of ang such Indian tribe to plan. conduct, and administer programs, or portions thereof, provided for in sectlons 452 to $\mathbf{4 5 7}$ of this title, any other program or portion thereof which the Becretary of the Interlor is authorized to adrininister for the benefit of Indians under sections 13 and $62 a$ of this title, and any Act subsequent thereto: Provtded, however, That the Secretary may initially decline to enter Into any contract requested by an Indian tribe If he finds that: (1) the service to be ren. dered to the Indian beneflclartes of the partlcu. lar program or function to be contracted will not be satisfactory; (2) adequate protection of trust resources is not sssured, or (3) the pro. posed project or function to be contracted for cannot be properly completed or malntained by the proposed contract: Provided further, That in arriving at his finding, the Secretary shall consider whether the trlbe or tribal organiza. tion would be deficient in performance under the contract with respect to (A) equipment, (B) bookkeoping and aocounting procedures, (C) aubstantive knowledge of the prosram to be contracted for, (D) community aupport for the contract, (E) adequately trained personnel, or (F) other necesary components of contract performance.

(b) Procedure upon refunal of requent to contract

Whenever the Becretary declines to enter Into a contract or contracts pursuant to subsection (a) of this section, he shall (1) state hls objections in writing to the tribe within sixty days, (2) provide to the extent practicable assistance to the tribe or trlbal organlation to overcome his stated objections, and ( 3 ) provide the tribe with a hearing, under such rules and regulations as he may promulgate, and the opportunity for appeal on the objectlons ralsed.

(c) Procurement of llabllity inuurance by tribe as pre. requiajte to exercise of contracting authority by Beeretary; required pollicy provlsions

The Becretary is authorized to require any tribe requesting that he enter into a contract pursuant to the provisions of this subchapter to obtain adequate liabllity Insurance: Provided, however, That each such policy of Insurance shall contain a provision that the insurance carrier shall walve any right it may have to ralse as a defense the tribe's soverelgn immunity from suit, but that such waiver shall extend only to claims the amount and nature of which are within the coverage and limits of the policy and shall not authorlze or empower such insurance carrier to walve or otherwlse limit the tribe's soverelgn Immunity outside or beyond the coverage and limits of the policy of insurance,

(Pub. I. 93-638, title I, 102, Jan. 4, 1975, 88 Stat. 2206.)

\section{Rexpraces in Text}

Bection $52 \mathrm{a}$ of this title, referred to in subsec. (a), wes repealed by Pub. L. 82-310, title II, $8229(\mathrm{c})(2)$, June 6, 1072, 86 Stat. 208.

This subchapter, referred to in subsec. (c), In the original read "thls title", meaning title I of Pub. L. 93638, which enacted sections 4001 to 460 n of this titio and section 2204b of Title 42, The Public Health and Welfare, and amended section 3371 of Title 5, Government Organiration and Employees, section 4762 of Title 42, and section 466 of Title 60. Appendix, War and National Defense. For complete classification of title I to the Code see Bhort Title note set out under section $\mathbf{4 5 0}$ of this title and Tubles volume.

\section{Ection REmuted to in OTHER Bections}

This section is referred to in sectlons $450 \mathrm{~h}, 450 \mathrm{~J}$, $450 \mathrm{~m}$ of this title; title 20 section 2303; title 42 section 2204b.

8450 g. Contracts by Secretary of Health, Bducation, and Welfare with tribal organization:

(a) Request by tribe for contract by Becrotary $10 \mathrm{Im}$. plement hospltal and health facility functions, authorities, and responsibilities; refusal of requeat

The Secretary of Health, Education, and Welfare is directed, upon the request of any Indian tribe, to enter into a contract or contracts with any tribal organization of any such Indian tribe to carry out any or all of his functions, authoritles, and responsibllities under the Act of 
August 5, 1954 (68 Stat. 674), as amended [42 U.S.C. 2001 et seq.J: Provided, however, That the Secretary may initially decline to enter into any contract requested by an Indian tribe if he finds that: (1) the service to be rendered to the Indian beneficlaries of the partlcular program or function to be contracted for will not be satisfactory; (2) adequate protection of trust resources is not assured; or (3) the proposed project or function to be contracted for cannot be properly completed or maintained by the proposed contract: Provided further, That the Secretary of Health, Education, and Welfare, In arriving at his finding, shall consider whether the tribe or tribal organization would be deficient in performance under the contract with respect to (A) equipment, (B) bookkeeplng and accounting procedures, (C) substantlve knowledge of the program to be contracted for, (D) com munity support for the contract, $(\mathrm{E})$ adequately tralned personnel, or (F) other necessary components of contract performance.

(b) Procedure upon refusal of request to contract

Whenever the Secretary of Health, Education, and Welfare declines to enter Into a contract or contracts pursuant to subsection (a) of this section. he shall (1) state his objections in writing to the tribe within sixty days: (2) provide, to the extent practicable, assistance to the tribe or tribal organization to overcome hls stated objectlons; and ( 3 ) provide the tribe with a hearing, under such rules and regulations as he shall promulgate, and the opportunity for appeal on the objections ralsed.

(c) Procurement of liability insurance by tribe as prerequisite to exercise of contracting authority by Secretary; required policy provisions

The Secretary of Health, Education, and Welfare is authorized to require any tribe requesting that he enter into a contract pursuant to the provisions of this subchapter to obtain adequate llability Insurance: Provided, however, That each such policy of Insurance shall con. tain a provision that the insurance carrler shall walve any right it may have to ralse as a de fense the tribe's sovereign Immunity from suit. but that such waiver shall extend only to claims the amount and nature of which are within the coverage and limits of the policy and shall not authorke or empower such insurance carrier to waive or otherwise limit the tribe's sovereign immunity outside or beyond the cov. erage and limits of the policy of insurance.

(Pub. L. 93-638, title I. 8 103, Jan. 4, 1976, 88 Stat. 2206.)

\section{Runencers in Twxt}

The Act of Aurust 5, 1954, as amended, referred to In subsec. (a), is act Aug. 5, 1054, ch. 688, 68 Btat. 674, amended, which is classlfied generally to subchapter I ( 8001 et seq.) of chapter 22 of Title 42. The Public Health and Welfare. For complete classification of this Act to the Code, see Tables volume.

Thls subchapter, referred to in subsec. (c), in the orloinal read "this title" meaning title I of Pub. I. 93638, which enacted sections 450 to $450 \mathrm{n}$ of this title and section 2004b of Title 12. The Public Health and Welfare, amended section 3371 of Title 5 , Government Orgianlation and Mmployees, section 1702 of Title 42, and section 456 of Title 30, Appendix, War and Nation. al Defense. For compiete clasaification of title I to the Code, $19 e$ Bhort Title note set out under ceotion 480 of this title, and Trbies volume.

\section{SEction RETERREd tO IN OTHER SEction:}

This section is referred to in sections $450 \mathrm{~h}$. 4s: $450 \mathrm{~m}$ of this title; title 20 section 2303 ; title 12 wetsin $2004 \mathrm{~b}$.

\section{\$ 460h. Grants to tribal organizations or triber}

(a) Request by tribe for contract or grant by sieste tary of the Interior for improving. elc.. Iettw governmental, contracting, and prosrem the ning activities

The Secretary of the Interior is authortens upon the request of any Indian tribe iffur funds appropriated for the benefit of Indiss pursuant to sections 13 and $52 \mathrm{a}$ of this tifir and any Act subsequent thereto) to contrin. with or make a grant or grants to any iribal is ganization for-

(1) the strengthening or Improvemrnt :: tribal government (Including, but not limites to, the development, Improvement, and at ministration of planning, financial maner ment, or merit personnel systems; the im provement of tribally funded programs of a tivitles; or the development, construction. its provement, malntenance, preservation, of wp eration of tribal facilities or resources);

(2) the planning, training, evaluation o: other activities designed to improve the : pacity of a tribal organization to enter into. contract or contracts pursuant to section is." of this title and the additional costs aser.s: ed with the initial years of operation unis. such a contract or contracts;

(3) the acquisition of land in conner: with Items (1) and (2) above: Provided I lio! in the case of land within reservation bui.ios arles or which adjoins on at least two siv. lands held in trust by the United Staira i., the tribe or for individual Indlans, the sivie tary of Interior may (upon request of u.e tribe) acquire such land in trust for the ffi:k or

(4) the planning, designing, monitoring evaluating of Federal programs sering li, tribe.

(b) Grants by Secretary of Heaith, Educution, ad Welfare for development, maintenance, is a health facilities or services and improvenom a contract capabilities Impiementing houpilal at health facility function:

The Secretary of Health, Education, and Hi: fare may, in accordance with regulations adop ed pursuant to section $450 \mathrm{k}$ of this title, mas. grants to any Indian tribe or tribal organimitua. for-

(1) the development, construction. obm : ation, provision, or maintenance of adeoust. health facilitles or services Including the training of personnel for such pork. live funds appropriated to the Indian Hralth $y_{*}$ vice for Indian health services or Indiw. health facilities; or

(2) planning, training, evaluation of oflice activities designed to (mprove the capmil) of a tribal organization to enter into a cuntra: or contracts pursuant to section $150 \mathrm{~s}$ of inis title.

(c) Use as matching shares for other similar Visher crant proctams

The provislons of any other Act noteuth standing, any funds made avaliable to a tsim: 
organization under erents purauant to this section may be used as matching shares for any other Federal grant prostams whlch contribute to the purposes for which grants under this sectlon are made.

(Pub. L. 93-638, tItle I, 104, Jan. 4, 1976, 88 Stat. 2207.)

\section{Rurmexcha in ThxT}

Section $82 \mathrm{~s}$ of this title, referred to in subsec. (a), wis repenled by Pub. I. 82-310, title II, 220(c)(2), June 6, 1972, 86 stat. 208.

\section{Bection Remento in Orten Bxcrion:}

This section is referred to in sectlons $400 \mathrm{~J}, 460 \mathrm{~m}$ of this title; titie 20 sectlon 2303; titje 42 section $2004 \mathrm{~b}$.

I 601 . Retention of Federal employee coverage, right and benents by employees of tribal organization:

(a) Ellgible employee; Federal employee programs subject to retention

Notwithstanding any other law, executive order, or administrative regulation, an employee serving under an appointment not limited to one year or less who leaves Federal employ. ment to be employed by a tribal organization on or before December 31, 1985, in connection with sovernmental or other activities which are or have been performed by employees in or for Indian communities is entitled, if the employee and the tribal organization so elect, to the following:

(1) To retaln coverage, rights, and benefits under subchapter I of chspter 81 ("Compensation for Work Injurles") of title 5 , and for this purpose his employment with the tribal organization shall be deemed employment by the United States. However, if an Injured em. ployee, or his dependents in case of his death, recelves from the tribal organlzation any payment (including an allowance, gratuity, pay. ment under an Insurance policy for which the premlum is wholly pald by the tribal organlzation, or other benefit of any kind) on account of the same Injury or death, the amount of that payment shall be credited against any benefit payable under subchapter 1 of chapter 81 of title 5, as follows:

(A) payments on account of injury or disabllity shall be credited against disabllity compensation payable to the Injured employee; and

(B) payments on account of death shall be credited against death compensation pay. able to dependents of the deceased employee.

(2) To retaln coverage, rights, and benefits under chapter 83 ("Retirement") of title 5. If necessary employee deductions and agency contributions in payment for coverage, rights, and benefits for the period of employment with the tribal organization are currently de. posited in the Civil Service Retirement and Disability Fund (section 8348 of title 5); and the perlod during which coverage, rights, and benefits are retained under this paragraph is deemed creditable service under section $83: 2$ of title 5. Days of unused sick leave to tise credil, of an employee under a formal leave system at the time the employee leaves Federal imployment to be employed by a tribal orgarization remain to his credit for retire- ment purposes during covered service with the tribal organization.

(3) To retain coverage, rights, and benefits under chapter 89 ("Health Insurance") of tItle 5, if necessary employee deductions and agency contributions in payment for the cov. erage, rights, and benefits for the period of employment with the tribal organlzation are currently deposited in the Employee's Health Benefit Fund (section 8909 of title 5); and the perlod during which coverage, rights, and benefits are retained under this paragraph is deemed service as an employee under chapter 89 of title 5.

(4) To retain coverage, rights, and benefits under chapter 87 ("Life Insurance") of title 5, If necessary employee deductions and agency contributions in payment for the coverage. rights, and benefits for the perlod of employ. ment with the tribal organizations are currently deposited In the Employee's Llfe Insur. ance Fund (section 8714 of title 5 ); and the perlod during which coverage, rights, and benefits are retained under thls paragraph is deemed service as an employee under chapter 87 of title 5.

(b) Deposit by tribal organization of employee deduc. tlon: and agency contributions In appropriate funds

During the perlod an employee is entitled to the coverage, rights, and benefits pursuant to the preceding subsection, the tribal organization employing such employee shall deposit currently in the appropriate funds the employ. ee deductions and agency contributions required by paragraphs (2), (3), and (4) of such preceding subsection.

(c) Election for retention by employee and tribal or. ganization before date of employment by tribal organization; transfer of employee to another tribal organization

An employee who is employed by a tribal organization under subsection (a) of this section and such tribal organlzation shall make the election to retain the coverages, rights, and beneflts in paragraphs (1), (2), (3), and (4) of such subsectlon (a) before the date of his $\mathrm{em}$ ployment by a trlbal organization. An employee who is employed by a tribal organlzation under subsection (a) of this section shall continue to be entltled to the benefits of such subsection if he is employed by another tribal organization to perform service in activitles of the type described in such subsection.

(d) Employee

For the purposes of subsections (a), (b), and (c) of this section, the term "employee" means an employee as defined in section 2105 of title s.

(e) Promulgation of Implementation regulations by President

The President may prescribe regulations necessary to carry out the provislons of subsections (a), (b). (c), and (d) of this section and to protect and assure the compensation, retirement, Insurance, leave, reemployment rights, and such other simliar civil service employment rights as he finds approprlate. 
(f) Additional employee employment rights

Anything in sections 205 and 207 of title 18 to the contrary notwithstanding, officers and employees of the United States assigned to an Indian tribe as authorized under section 3372 of title 5 , or section 48 of this title and former officers and employees of the United States employed by Indian tribes may act as acents. or attorneys for or appear on behalf of such tribes In connection wth' any matter pending before any department, agency, court, or commission, Including any matter in which the United States is a party or has a direct and substantial interest: Provided, That each such offlcer or employee or former officer or employee must advise in writing the head of the department. agency, court, or commlasion with which he is dealing or appearing on behalf of the tribe of any personal and substantial Involvement he may have had as an offlcer or employee of the United States in connection with the matter involved.

(Pub. I. 93-638, title I, \& 106(e)-(j), Jan. 4, 1975, 88 Stat. 2208.)

\section{Codiricatio:}

Section is comprised of subsecs. (e) to (j) of section 105 of Pub. L 83-638, whlch for purposes of clessiftice. tion have been redesignated as subsecs. (a) to (f), respectively. Subsecs. (a) to (d) of Pub. L 03-638 are classifled to sectlon 3371 of Title B. Government Organlation and Employees, section 2004b of Title 12. The Public Health and Welfare, section 466 of Title $80 . \mathrm{Ap}$ pendix, War and National Defense, and section 4762 of tItle 42, respectively.

Ex. ORd, No. 11899. Providina ron Protection or Cer. TAIF CIVIL SERVICE EMPLOYMENT RIOHTS OP Promer.

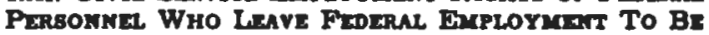
BuploYtD BY TRIBAL OROANIRATIOX:

Ex. Ord. No. 11890, Jan. 26, 1976, 11 F.R. 3460, provided:

By virtue of the authority vested in me by section $108(1)$ of the Indian Belf-Determination and Education Assistance Act (88 Stat. 2210, 25 U.8.C. 450(1)), [subsec. (e) of this section] section 3301 of title $B$ of the United Stutes Code, section 301 of title 3 of the Unlted Btates Code, and as President of the United Btates of America, it in hereby ordered as follows:

Section 1. The United Btates Civil Bervice Commls. sion is hereby desimated and empowered to oxercise, without approval, ratification, or other action by the President, but after consultation with the Department of the Interlor and the Department of Health, Iducatlon, and Welfare, the authority vested in the Preal. dent by section 108(1) of the Indian Belf-Determina. tlon and Education Asstatance Act [subsec. (e) of this section' (hereinafter referred to as the Act), to lasue regulations necessary to carty out the provisions of subsectlon $(e \times 2),(e \times 3),(e)(4),(f),(g)$ and $(h)$ of sec. tlon 105 of the act, Isubsecs. (a)(2), (3), (4), (b), (c), and (d) of this sectionj, to carry out the provisjons of sub. ection (e) (1) of sectlon 105 of the set tsubsec. (a) (1) of this sectioni pertalns to section 8151 of tItle $B$ of the United States Code, and to protect and asoure any other clvil service employment riehts which it finds appropriate.

Bec. 2. The United Btates Civl Bervloe Commisalon shall, after consultation with the Department of the Interior and the Department of Health, Education. and Welfare, lave reculation, as it deem appropriate, providins for the establishment, granting, and exercise of reemployment rights for employees who letve Federal employment for employment by an Indian tribal ormanization under provislons of the act.

'So in orieginal. Probebly should read "with".
Sec. 3. The Secretary of Labor is hereby designuler and empowered to exercise, without approval, raticy tion, or other action by the President, the autharly vested in the President by section 105(1) of the or [subsec: (e) of this section] to issue regulations necto sary to carry out the provisions of section $105(\mathrm{e})(1)$ of the act [subsec. (a)(1) of this section], except as pro vided in section 1 of this order.

\section{Gerned R. Paw}

SEction Rerment to in OThan SEctions

This section is referred; to in title 20 section 2303.

$6450 j$. Contract or grant provisions and administre tion

(a) Applicability of Pederal contracting laws and me ulatione; waiver of requirement

Contracts with tribal organizations pursuan to sections 450 and $450 \mathrm{~g}$ of this title shall be in accordance with all Federal contracting law and regulations except that, in the discretion of the approprlate Secretary, such contracts mar be negotlated without advertising and need nol conform with the provisions of sections $270 \mathrm{n}$ to 270d of title 40: Provided, That the appropriste Secretary may waive any provisions of such contracting laws or regulations which he dries. mines are not appropriate for the purposes of the contract involved or inconsistent. with the provisions of this Act.

(b) Payments; transfer of funds by Treasury for th bursement by tribal organization; accountublut for intereat accrued prior to disbursement

Payments of any grants or under any con tracts pursuant to section $450 \mathrm{f}, 450 \mathrm{~g}$, or $450 \mathrm{~h}$ of this title may be made in advance or by wy of reimbursement and in such installments and on such conditions as the appropriate Secretars deems necessary to carry out the purposes af this subchapter. The transfer of funds shall be scheduled consistent with program requir ments and applicable Treasury regulation as to minimize the time elapsing between the transfer of such funds from the United Sules Treasury and the disbursement thereof by the tribal organization, whether such disbursemms occurs prior to or subsequent to such tranisy of funds. Tribal organizations shall not be brid accounteble for interest earned on such fund pending tholr disbursement by such orsenim tion.

(c) Term of requented contricts; annual rencroulaties Any contract requested by a tribe pursuent to sections 450 f and $450 \mathrm{~g}$ of this title shall be for term not to exceed one year unless the apore priate Secretary determines that a longer tc.T would be advisable: Provided. That sich tern may not exceed three years and shall be subsrrt to the avallabllity of appropriations: Proride further, That the amounts of such contrare may be renegotiated annually to reflect farton Including but not limited to cost increnes beyond the control of a tribal organization.

(d) Revision of amendment of provitions of rmen or with conment of tribal orsanization: eflurtw. date for retrocession of contract

Notwithstanding any provision of inw 10 the contrary, the appropriate Secretary may if the request or consent of a tribal organieatior. revise or amend any contract or crant madr b) him pursuant to section $450 \mathrm{f}, 450 \mathrm{r}$. or $450 \mathrm{~h}$ of this title with suoh orgenlzation as necearary to 
carry out the purposes of this aubchapter: Pro. ofded, however, That whenever an Indian tribe requests retrocession of the appropriate Becretary for any contract entered Into pursuant to this Act, such retrocession shall become effec. tive upon a date speclfied by the appropriate Secretary not more than one hundred and twenty days from the date of the request by the tribe or at such later date as may be mutu. ally agreed to by the appropriate Becretary and the tribe.

(e) Implementation by tribal organization with existing school bulldings, hospltals, and facillties and equipment and other Government owned person. al property

In connection with any contract or grant made pursuant to section $450 \mathrm{f}, 450 \mathrm{~g}$, or $450 \mathrm{~h}$ of this title, the appropriate Becretary may permit - tribal organization to utllize, in carrying out such contract or grant, exlsting school build. ings, hospitals, and other facllitles and all equipment therein or appertaining thereto and other personal property owned by the Government within his Jurisdiction under such terms and conditions as may be agreed upon for their use and maintenance.

in Performance of personal services

The contracts authorlzed under sections $450 \mathrm{f}$ and $450 \mathrm{~g}$ of this title and grants pursuant to section $450 \mathrm{~h}$ of this title may include provisions for the performance of personal services which would otherwise be performed by Federal employees including, but in no way limited to, functions such as determination of eligibility of applicants for assistance, benefits, or services, and the extent or amount of such assistance, benefits, or services to be provided and the provisions of such assistance, benefits, or services, all In accordance with the terms of the contract or srant and applicable rules and regulations of the appropriate.Secretary: Provided, That the Secretary shall not make any contract which would impair his ability to discharge his trust responsibilities to any Indian tribe or Individuals.

(8) Falr and uniform provlajon by tribal organization of aervices and asolatance to covered Indians

Contracts and srants with tribal organizations pursuant to sectlons $450 \mathrm{f}, 450 \mathrm{~g}$, and $450 \mathrm{~h}$ of this title and the rules and regulations adopted by the Secretaries of the Interior and Health, Education, and Welfare pursuant to section $450 \mathrm{k}$ of this title shall include provisions to assure the fair and uniform provision by such tribal organizations of the services and assistance they provide to Indians under such contracts and grants.

(h) Minimum amount of contracts

The amount of funds provided under the terms of contracts entered into pursuant to sectlons 450 and $450 \mathrm{~g}$ of this title shall not be less than the appropriate Secretary would have oth. erwise provided for his direct operation of the programs or portions thereol for the period covered by the contract: Provided, That any savings in operation under such contracts shall be utllized to provide additonal' services or benefits under the contract.

'Bo in orferinel. Probably should read "additional".
(Pub. L. 93-638, title I, 106, Jan. 4, 1975, 88 Stat. 2210.)

\section{Rarentices Ix TExT}

This Act, referred to in subsecs. (s) and (d), is the Indian Belf-Determination and Education Assistance Act, which is Pub. L. 93-638, Jan. 4, 1975, B8 Stat. 2203. Por complete classification of this Act to the Code, see Bhort Title note set out under sectlon $\mathbf{4 5 0}$ of this title and Tables volume.

This subchspter, reforred to in subsecs. (b) and (d), in the orlginal read "this title", meaning title I of Pub. I. 93-638, which enacted sections 450 to 450 n of this title and sectlons 2004b of Title 42, The Public Health and Welfare, and amended sections 3371 of Title 5 . Government Orrunization and Employees, section 1762 of Title 42 , and section 486 of Title 50. Appendix. War and National Defense. For complete classification of title I to the Code, see Bhort Title note set out under section $\mathbf{4 8 0}$ of this title and Tables volume.

SEction REFmud to IN OThER BEctions

Thls sectlon is referred to in title 20 section 2303.

$\$ 450 \mathrm{k}$. Rules and regulation.

(a) Authority of Secretaries of the Interlor and of Health, Education, and Welfare to perform any and all acts and make necessary and proper rules and resulations

The Secretaries of the Interior and of Health, Education, and Welfare are each authorized to perform any and all acts and to make such rules and regulations as may be necessary and proper for the purposes of carrying out the provisions of this subchapter.

(b) Consultation, presentation, publication, and promulgation; time and procedural requirements

(1) WIthin six months from January 4, 1875, the Secretary of the Interior and the Secretary of Health, Education, and Welfare shall each to the extent practicable, consult with national and regional Indian organizations to consider and formulate appropriate rules and regulations to implement the provisions of this subchapter.

(2) Within seven months from January 4 , 1975, the Secretary of the Interlor and the Sec. retary of Health, Education, and Welfare shall each present the proposed rules and regulatlons to the Committees on Interior and Insular Affairs of the United States Senate and House of Representatives.

(3) Within elght months from January 4: 1975. the Secretary of the Interior and the Secretary of Health, Education, and Welfare shall publish proposed rules and regulations in the Federal Reglster for the purpose of receiving comments from interested partles.

(4) Within ten months from January 4, 1975, the Secretary of the Interlor and the Secretary of Health, Education, and Welfare shall promulgate rules and regulations to Implement the provisions of this subchapter.

(c) Revislons and amendments: procedures applicable

The Secretary of the Interior and the Secretary of Health, Iducation, and Welfare are authorized to revise and amend any rules or regulatlons promulgated pursuant to this section: Provided, That prlor to any revision or amendment to such rules or regulations, the respective Secretary or Secretarles shall present the proposed revision or amendment to the Com. mittees on Interior and Insular Affatrs of the 
United States Senate and House of Representa. tives and shall, to the extent practicable, con. sult with appropriate national or regional Indian organizations and shall publish any proposed revisions In the Federal Register not less than sixty days prior to the effective date of such rules and regulations in order to provide adequate notice to, and receive comments from. other interested parties.

(Pub. L. 93-638, title I. 8 107, Jan. 4, 1975, 88 Stat. 2212.)

\section{Rematices in Text}

This subchapter, referred to in subsecs. (a), (b)(1), (4). In the original read "thls title", meaning title I of Pub. L. 93-638, whlch enacted sectlons 460f to $450 \mathrm{n}$ of this title and section $2004 \mathrm{~b}$ of Title 42. The Public Health and Welfare, and amended sectlon 3371 of Title 5, Government Organization and Employees, section 4762 of Title 12 , and section 466 of Title 50, Appendix, War and National Defense. For complete clasalfication of title I to the Code, see Bhort Title note set out under section $\mathbf{4 0}$ of this title and Tables volume.

\section{Chanos or Nane}

The Committee on Interlor and Insular Affalrs of the Senate was abolished and replaced by the Committee on Fnergy and Natural Resources of the Senate, Bffective Feb. 11, 1977. Bee Rule XXV of the Standing Rules of the Benate, as amended by Senate Resolution 4 (popularly clted as the "Committee Bystem Reorganizstion Amendments of 1977"), approved Feb. 4, 1977.

\section{Brctron RETWRED TO IN OTHER SECTIONS}

This section is referred to in sectlons $450 \mathrm{~h}, 460 \mathrm{~J}$ of this title; tItle 20 section 2303.

8 450l. Report by tribe requesting contract or grant; contents

For each flscal year during which an Indian tribal organization recelves or expends funds pursuant to a contract or grant under thls subchapter, the Indian tribe which requested such contract or grant shall submit to the appropriate Secretary a report including, but not limited to, an accounting of the amounts and pur. poses for which Federal funds were expended, information on the conduct of the program or service Involved, and such other Information as the appropriate Secretary may request.

(Pub. L. 93-638, title I, 8 108, Jan. 4, 1976, 88 Btat. 2212.)

\section{Rrrmences in Text}

This subchepter, referred to in text, in the original read "this title", meaning title I of Pub. L. 93-038, whlch enacted soctlons 480 to $450 \mathrm{n}$ of this title and section 2004b of Title 12, The Public Health and Wel. furn, and amended section 8871 of Title 8 , Covernment Orcaniantion and Imployees, sectlon 1762 of Title 42 , and wection 456 of THtle 50 , Appendix, War and Nation. al Defense. For complete clasalfication of title 1 to the Code, see short Title note set out under wection $\mathbf{4 5 0}$ of thlo t|tle and Tables volume.

\section{8sotion REmento to in OtKen 8xctrome}

Thiw section in referred to in title 20 section 2303.
$8450 \mathrm{~m}$. Rescission of contract or grant and assumption of control of prosram, etc.; authority: Erounds; procedure; correction of violation a prerequisite to new contract or grant agreement; construction with occupational safety and health requirements

Each contract or grant agreement entered Into pursuant to sections $450 \mathrm{f}, 450 \mathrm{~g}$, and $450 \mathrm{~h}$ of this title shall provide that in any case where the appropriate secretary determines that the tribal organization's performance under such contract or grant agreement involves (1) the violation of the rights or endangerment of the health, safety, or welfare of any persons; or (2) gross negligence or mismanagement in the handling or use of funds provided to the tribal organization pursuant to such contract or grant agreement, such Secretary may, under regulations prescribed by him and after providing notice and hearing to such tribal organization. rescind such contract or grant agreement and assume or resume control or operation of the program, activity, or service Involved if he determines that the tribal organization has not taken corrective action as prescribed by him: Provided, That the appropriate Secretary may. upon notice to a tribal organization, immediate. ly rescind a contract or grant and resume con. trol or operation of a program, activity, or ser. vice if he finds that there is an Immedlate threat to safety and, in such cases, he shall hold a hearing on such action within ten days thereof. Buch Secretary may decline to enter Into a new contract or grant agreement and retain control of such program, actlvity, or ser. vice untll such time as he is satisfied that the violations of rights or endangerment of heaith. safety, or welfare which necessitated the rescis. sion has been corrected. Nothing in this section shall be construed as contravening the Occupa. tlonal Safety and Health Act of 1970, as amend. ed [29 U.S.C. 651 et seq.].

(Pub. L. 93-638, title I, 109, Jan. 4, 1975, 8 Stat. 2212.)

\section{Rerarances in Text}

The Occupational Safety and Health Act of 1870, amended, referred to in text, is Pub. I. 91-598, Dec. $x$. 1970, 84 8tat. 1590, as amended, which is clasalfied princlpally to chapter 18 (\$ 653 et seq.) of Tille $z$ Labor. For complete clasalfication of this Act 10 the Code, see Short Title note set out under section 851 of Title 29 and Tables volume.

\section{Bection Rereando to In OTHEx Bxctiono}

Thl section is referred to in title 20 rection 2303. $8450 \mathrm{n}$. Sovereign immunity and truateeship rictu
unaffected

Nothine in thls Act shall be construed s(1) affectins, modleying, diminishine, of otherwiae impalring the sovereim immunily from sult enjoyed by an Indian tribe; or

(2) authorizing or requiring the termination of any existing trust responslbility of the United States with respect to the Indian people.

(Pub. L. 93-638, title I, 110, Jan. 4, 1976. U Stat. 2213.) 


\section{APPENDIX C \\ Arizona Johnson-0'Malley State Educational Plan \\ $1977-1978$}

1 


\section{PURPOSE}

A. The philosophy of Indlan Education in the state of Arizone for the intent and purposes of the 1977-1978 Arizona.Johnson-! U'Malley State Educational Plan and such other programs or services created for the benefit of Indian children shall be the assurance of quantity and quality educational opportunities of all Indian childrea and to alntain the culcural integrity

- of Indian tribea through the axinization of parental. tribal, and teácher involvewent in the development of seld opportunities." for Indian youth.

B. To provide a comprehensive educational plan for the 1977-1978 school year to assure programatic and flscal accountability In (1) supplemental programa and special services, (2) parental participation, (3) operational expenditurea, and (4) edministrative managemt to neet the specialized and unlque educational needs of Indian youth.

c." To prescribe the proceduree by which contract funds way be progranned to el1gible public echool districts particlpating in the Johnson-0'Malley Program and educating ellgible Indian ch11dren, or, to one or wore Arizona Indian tribes under the provisione of the Intergovernmental Agreement, or Indlan corporations pursuant to P.L.93-638.

D. To provide and foster the intent of the Congress of the United States pursuant to the Indian Self-Determination and Education Asalstance Act of 1975, P.L.93-638:

"The Congress decleres that afor national goal of the United states 18 to provide the quentity.. and quality of educational services and opportunities which wil peritit Indian children to complete and excel in the life areas of the1r cholce, and to achleve the measure of self-detemination essential to the $1 \mathrm{r}$ accilal and economic well-belng."

E. To provide educationsl benefits for Indian youth in support of the atate educational requirements, or such other educational programs and service required by federal or atate laws, and to provide training and eaployment opportunteles for Indlan youth and the affected Indian comunities.

\section{COALS}

A. To Increase acadeatc and cultural knowledge of Indian youth through the devalopment of aupplementary programs based upon locel assessments and goale, .........

B. To Increase student oelf-ewareness in educational programs and services avallable or planned through apecial intereat profects created under this Plan. 
C. To Increase parental participation wthin the local education agency through the programs created under thia'plan and such other services ade avallable in the Arizona Departwent of Education.

D. To reduce the percentum of Indian youth dropout from public schools through the specialized prograng created under this Plan.

E. To develop proficiency of Indian youth In the language and comminications okills.

POLICIES

A. The provisions of the 1977-1978 Arizona Johneon-0'Malley State Educational Plan hall be executed in accordance with (1) atate laws applicable to the education of all children, (2) secretarial policles, and (3) bona f1de contracts purauant to P.L.93-638. The distribution of contract funds 111 be ade in support of the programs and services of this Plan to ellgible appilcants pursuant to 25 CFR 273.11 and ARS 11-951.

B. All comitmente and distributions of contract funde under this Plan are subject to funds being ade avallable to the Bureau of Indlan Affairs and ahall be expended for the benefit of el1gible Indian children as approved on project basis wth separate flscal accountability. It shall be required that the approved expenditures of the Indian Education Comittees in the performance of their dutles under this Plan shall be for the benefit of eligible Ind Ian children. All applicants shall subalt an application or resolution to participate in the Johnson-0'Malley Progras as provided by this plan and subject to avallable funds for supplementary or operational prograns.

$$
\text { , ' }
$$

C. Appropriations authorized under Johnson-O'Malley Act of 1934, as amended, shall supplement, not supplant, state and local funds; use of sald funds shall not result in decrease of atate, local. or federal funds, and that wuch other sources must be used to provide comparable services to non-Iadian and Indian students prior to the use of Johnson-0'Malley funds; in no Instance shall these funds be used as payment for captial outlay or debt ret1rement expenses (except where such capital costs are allowable for such equipment necessary for implementation of the project and/or approved by the Phoenix Area office, contracting office, or It $\mathrm{B}$ authorized representative).

D. Each applicant shall prepare, mantain, and certify the eliglble Indian student enrollment to be served. A copy of euch certification, together with the names, tribai ffillation, age, and grade level of the Individual scudents shall be malicained at the local district or tribal office. A letter of certification of the total eligible Indian enrollment at the close of the second school month shail be submitted to the Division of Ind Ian Education.

E. Funds w1Il be distributed based on the estimated eligible Indian student enrollment to be served and may be subject to such provisions for adjustment of funds to the actual number of chlddren 
being served in the laut quarter of the school year.

F. In the absence of federal regulations, the state Board of Education shall determine the purpose and wethods of expend1cure and shall be the chlef educational authority for the administration and aupervision of the expenditure of federal appropriatione.

C. Th1 Plan may be anended by the mutual coneent and approval of the signed parties as a result of changes in elther state or federal law or regulations applicable to P.L.73-167 and financ1al ald for public inatruction. Any program or project under this Plan may be reviaed or amended as deened necesary to carry out the purposes of the progran or project. However, no program approved by the Indian Education Commitee shall be altered from the time of 1 ts original approval to the end of the contract period without the uritten approval of the Comittee.

H. Arizona Ind ian tribes and Ind Ian corporations within.the admintatrative jurisdiction of the Phoenix Area Office, Bureau of Indian Af falrs, ay participate and recelve assiatance or services under the provisions of this Plan pursuant to the Intergovernmental Agreenent for educational purposes consistent with requirements. of CFR Part 273 and 41 CPR Part 1.

I. All supplementary programs or projects and applicable sub-contracts or Intergovernmental Agreements shall provide an opportunity and consideration for the employment and training of members of the af fected Indian community. This proviaion may be waived by the local Indian Education Comittee, provided that all programs or projects authorized under this Plan, shall utilize the best available talents and resources from the Indian communities; sald walver shall be recorded in the official minutes of the affected comint tee (s).

1. Unused funds for operational or supplemental programs/projects may be carried forward to the succeeding fiscal year's program, or as a credit to the tubsequent year's program as approved by the Division of Indian Education and upon the written request of the Indian Education Compltee; hovever, all funds not expended, obligated, or used for the purposes of this Plan, or, unlawfully expended shall be returned to the Division of Indian Education.

K. Budgets for operational and supplementary programs/projects may be adjusted within the contract period to an amount which will be not more than 10 percent of an increase or decrease within a line 1tem. Adjustments in excess of 10 percent shall be first approved by the Indian Education Comittee and the Division of Indian Education.

L. All supplementary programs shall require the establishment of a local Indian education Comaltee composed of parents of Indian chlldren being gerved, where applicable, Ind Ian high school students, and exercise all authorities granted thereto by the Indian SelfDetermination and Education Assistance Act P.L.93-638. Sald 
Committee shall be nominated or selected, and served by procedures determined by the Indian comminty affected or as delineated in the constitution and bylaws of each comittee. All proposals shall require the maximum and continuing parental particlpation In the planning, developinent, approval or disapproval, and Implementation of ali prograns established under this Plan. All amendments to program pursuant to this Plan shall require the prior approval of the appropriate Indian Education Comittee.

M. Where a local school board is NOT COMPOSED of a majority of Indian people, the parents of Indian children enrolled shall establish a local Indlan Education Conmittee from the $1 \mathrm{r}$ members and shall have such authoritles granted thereto by 25 CFR Part 273.16 and in iurcher compliance with such federal, state, and local laws or regulations applicable to federal assistance for educational purposes.

N. Whenever a local Indian Comittee or Comittees established pursuant to Section 305 of the Act of June 23, 1972 (Title IV P.L.92-318) or an Indian Advisory School Board(s) established pursuant to P.L.93-638, January 4, 1975, exists in such school district, or Indian community, such committee or board may, in the discretion of the af fected district or tribal governing body or bodies, be utilized as the Indian Education Comiltee.

0. For purposes of this Plan, where the elected public school boards of trustees are composed of a MUNORITY of Indian people, said board. may serve as the local Indian Education Comittee, provided that such shall not limit the continuing participation of parents of Indian children being served and members of the Indian Committee affected. In such instances, the elected public school board of trustees shall establish a cubcomittae for supplementary programs to be composed of parents of children being served, and exercise such duties and functions consistent with the recipient agency.

P. Where funds are distributed to a public school district, Arizona Indian Tribe (pursuant to an Intergovernmental Agreement,) or, to an Ind Ian corporation pursuant to this Plan, the establishant of an Indian Education Comittee shall be required and consistent with such administrative/fiscal pollcies and procedures deternined by the tribal governing body or bodies. The affected public school board of trustees or governing bodles shall not delegate away their authority as the prime applicant in recelpt and fiscal disposition of federal appropriations for educational purposes.

Q. Whenever an Indlan Education Cowittee, established under the provisions of this Plan la confronted by an impasse on program negotiation or implementation or is constrained in the exercise of its duties, the Division of Indian Education and the duly authorized representative of the Secretary of Interlor may be requested to mediate such proceedings and shall of fer recowendetions in the best interest of the students being served.

R. The Indian Education Comitcee(s) may recomend to the Comisoloner of Indian Affalrs and/or the State Board of Education through the appropriate Bureau contracting officer's representative cancellation or suspension of a contract (a) or project (s) which contains 
the program (s) approved by the Indian Education Comittee if the applicant falls to peralt such Comalt tee to exercise its powers and duties an specifled by 25 CFR Part 273.16. Where funds are diatributed to Arizona Indian tribes of Indian corporations pursuant to this Plan, such recomendatione may be ade through approprlace governing body or bodies.

S. Each Indian Education Comalttee established under th1s Plan may establish an executive panel from Its members, as needed, to hear grlevances, coments, recomendations, or such other presentations in relationship to the program or services created under this Plan, or as delineated in each committee's consticution and bylaws for such purposen. Sald panel may conduct it. hearings in executive oessions, provided, that adequate advance notice is presented to the affected parties.

T. Indian Education Comittees shall establish criterla and procedures for Intervlewing applicants for applicable position (s) created under the provisiona of this Plan, provided, that any recommendationa for employment shall be consistent with the recipient agency (applicant) and that the basis of quallfications for any position should be estabilished in the position description pursuant to the degree of professional requirement and progran need.

U. All school digtricts receiving funds under this Plan may provide members of the Indian Education Comittee access to non-conf1dential records concerning atudents served by the Johnson-o'Malley program, provided, that written approvals mall be given by the parents or guardians of acudents being aerved in compliance with the Freedom of Inforation, Invasion of Personal Privacy Acts, and Protection of the Rights and Privacy of Parents and Student: (5 USC 552 P.L.93-502, 88 STAT.1561; P.L.93-380, 88 STAT.574).

PROGRAMS AND SERVICES

A. SUPPLEMEKTAL

1. Supplementary prograns or projects are those which shall be designed to meet the apecial and unique educational needs of ellgible Indian children, from 3 years old through grades 12 , and to creace and enhance educational opportunities as provided by this Plan in compliance with applicable federal, state, and local laws and regulations, or, such other programa or profecte designed to increase proficiency in an educational standard or requirement. Funds for supplemental programs shall be expended by line Ited for lavful purposes authorlzed by the Indian Education Comalttee(s) and may be used to supplement other educational prograns, provided, that such shall neither supplant nor be used proportionaliy unless approved by the Division of Indian Education upon the written request of the Indian Education Committee.

2. Supplementary funds may be awarded to an eligible applicant in the following manner. further subject to avallable funda:

1. based ent1rely on the approved eupplemental program or project eubaltced by an applicant 
and designed to net the special needs of all or a portion of the eligible Indian student enroliment; or,

11. per capita payment based on the product obtained fron the division of the total available funds by the number of eligible Indian students enrolled at the close of the second school month times the factor for elementary and high school atudents or such other factors a are mutully determined by the signing parties.

3. To recelve fundings, a supplementary progran or project proposal ohall establish the following:

a. Eligible Indian Studencs

b. Indian Education Comittee (aasurancea)

c. Budget (line Items)

d. Needs Assessment

e. Coals

f. Objectives

B. Activities

h. Evaluation

1. Monltoring System

J. Calendar of Event

k. Dissemination

1. IEC Constitution and Bylawa

4. Supplementary program/project expenditures may includa the following: (a) personal alaries, fringe benefits, bus drivers. and specialists; (b) transportation (field trips) for out of classroom activities for cultural enrichment or special events: (c) Indian cultural or heritage atudies; (d) Indian Education Counittee expenses in performance of duties; (e) conference, workshop, and seminar fee incurred by Ind 1 an students, the Indian Education Commitcee, or program personnel; (f) special services or equipment for physically handicapped and mentally retarded children; (8) text or reference book necessitated by the prograns or projects; (h) training costs by the Indian ... Education Comitcee or prograx personnel; (1) consultant fees necessitated by the program or project which benefits shall rusult in proficlency or effectiveness of goals and objectives; (j) equipment and supplies directly related to the program or profect to benefit ellgible Indian students being served; $1 . e$. band instruments, arts and crafts 1tems, etc; (k) sumer school or special interest oumer programs (educat lonally measurable) or summer work/study programs; (1) rental or lease of equipment necessary to Implement project: (a) parental costs.

5. Parental costs shall be expenditures for emergency and/or, unusual circumstances to benefic all or a portion of the eligible Indian students as approved by the local Indian Education Comiltee pursuant to such criterion developed for th1s purpose and applied uniformly in support of supplementary programs/projecte which may include the following; however, G.E.D. or I1vestock expend 1tures are prohibited. 
6. Program expenditures may supplement the instructional and supportive services identified under the provisions of the Indian Education Act of 1972 (Title IV, P.L.92-318), provided, that such expenditures will not supplant any funds under such Act, and that such programs are in addition to or complementary to the basic educational programs offered by the affected school district or Indian tribe(s).

7. Supplewental programs may be operated on premises within or without the school district boundaries, or at such other facilities maintained by a tribal government. Indian corporation, or the Bureau of Indian Affairs adequately facilitated to accommodate said programs, provided, that when supplementary programs designed to extend the classroom participation of eligible Indian students beyond the school premises and during normal school houra the State compulsory scbool attendance laws shall govern.

B. OPERATIOHAL SUPPORT PROGRAMS

1. Programatic expenditures made in support of operational costs incurred by eligible and participating public school districts educating eligible Indian ch1ldren to seet educational require-" ments established in ARS Title 15 - Education and Policles of the State Board of Education. All fiscal procedures/expenditures for this purpose shall be executed pursuant to ARS 15-1161 and Un1form System of F1nancial Records/Chart of Accounts.

2. To be eligible for operational expenditure funding or consideration a school district shall establish all of the following:

a. That there exist at least 70 percent or more of el1g1ble Indian children within the school district or within any particular school served.

b. All other sources of financial ald or revenues to which the district is entitled are utilized, including all forms of state a1d, P.L.81-874 funds, balances forward, and funds raised from a local tax levy based on the qualifying Johnsono'Malley rate established by the Arizona Department of Education.

c. That the district has made a reasonable tax effort with a will levy in support of education programs at least equal to the state average, being the rate not less than the average levied by all similar districts in the state during the previous year, excluding special levies and bonded indebtedness. The average tax rate 18 to be developed separately for elementary districts and h1gh school districts which will be a simple average tax rate as used in the annual report of the Department of Public Instruction. Whenever applicable, a unified school district way use the unified rate.

d. That the district cannot satisfy the minimum state standards or requirements in the absence of such funds. 
C. SPECIAL SERVICES

1. Special mervices my be provided for apecial extraordinary needs or c1rcumstancee, and energency services which ayy be provided to a public echool district, Indian child, Arizoan Indian tribe, Arizone Indian Education Aanociation, or an Indian corporation, to enhance or enrich oducational opportunities and upgrade the quality of education for Indian childrea. Prloritiea may be given to Indian children participating in special educational programs for trainable and educable youth. provided, that all other resources are fully utilized.

2. Funds for this purpose shall be malatained in the operational budget of the Division of Indian Education. Awards for Special Service Projecta ahall be approved by the igned parties on a line item basis, or by cuch other procedures as witually detereined by the contract officers' representativas.

3. Applicante may subait requests for assietence, wth witten justificatione, or atatenents of needs consistent uth the provisions of this Plan for suppleaentary prograse/projects and the provisions of iten 2 of this part to the Division of Indian Bducation.

\section{ADMINISTMATION AND MAMGgIENT}

A. The Bureau shall provide funde for administrative and anagesent costs to carry out the contracted Johnson-0'mley Erogran, and the provisione of the 1977-1978 Artzona Johneon-0'Helley State Bducational Plan.

B. The Arizona Department of Education, Divialon of Indian Education, may be whorized by the State Boerd of Bducation to be responsibie for the administration and wangesent of all prograna and cervices executed under the authority of the Johnson-0'Malley Act and ARS 15-1161, and my perform euch other functions as required or delegated by the Superintendent of Public Inatruction. Such reaponefbilities ahall include final disposition of proposal aubitted under this plan for funding and statutory coapliances. The Divialon of Indian Bducation shall be staffed by an adequate staff to carry out the provisions of this Plan and contractual agreenente.

c. Additional functions or activities of the pivision of Indian rducation may be performed to coordinate other atate, federal, or local programa applicable to the educational and special needs of Indian children and the Indian commities, and, upon request, to the ganeral public.

D. The Division of Indian Education shall be reaponeible for malntainIng all documente such as Involces, purchase orders, cancelled checks, balance sheete, and 11 other records relating to financial transactions to facilitate auditing, and aintain other documents relating to the adalnistration of the contract. The records involved in any claim or expenditure wich has been questioned ahall be further alntalned unt1l final detervination has been ande on the questioned expenditures. 
E. The Arizona Department of Education shall make an annual report to the approving of ficial and the participating Indian Education Committees on or before September is for the previous school year, and include, but not be limited to, (a) an accounting of the amounts and purposes for which the contract funds were expended, (b) information on the conduct of the program, (c) a quantitative evaluation of the eriectiveness of the stated gow is and objectives contained in the applicant's educational plans, prograns, and projects and such other documents required by the signed contract.

P. All applicants particlpating "noi's this Plan shall submit the following information on or betore July 30 of each year for said annual report. (A atate sumary report form 111 be aupplied by the DIvision of IndIan Education.)

1. Nuber of ellgible Indlan eighth grade and twelfth grade graduatea each year.

2. Report to the Division of Indian Education total enrollnent of Indian atudents by grade and age in the Johnson-0'Malley participnting schools (kindergurten through grade 12 ).

3. Report number of dropouts and transfers by-grade and age, including reason for leaving school.

4. Total achool enrollment Including Indlan and nonIndian students.

5. All applicants shall further submit perlodic progress reports on progran activities and current flecal expenditures on or before December 31, 1977, and April 30,1978 in addition to the annual report noted bove.

6. Copies of each Indlan Education Comittee' shall be aubitited as approved.

GENERAL PROVISIONS

A. All public schools districts and Indian tribes receiving funds under thia Plan shall comply wh Ticle VI of the Civil Rights Act. "No person in the United States shall, on the grounds of race, color or hational origin be excluded from participation in, be denied the benefics of, or be subject to discrimination under any program or activity receiving federal financlal assistance."

B. All funds provided by this Plan, shell be expended only for the benefit of eligible Indian students, provided, that where students other than eliglble Indian atudents participate in programs contracted under this part, money expended under such contract shall be prorated to cover the particlpation of only the eligible Indian atudents, except where the participation of non-eligible students is so incidental as to be de minimus. Such de ininims participation must be approved by the Indian Education Comittee. 
C. All progran or projects funded under this Plan shall be open for visitations and inepection by the contractor or a duly authorized. representative of the Secretary of the Interior or members of the Indian Education Comittee to monitor, evaluate, and audit program effectiveness and financial expenditures.

D. School districts receiving funds under the Johnson-0'Malley Act shall provide educational opportunitiea to all Indian children within that school district or school on the same terms and under the same conditions which apply to all other students, and shall insure that Indian children receive all ald from all sources which they would be entitled to recelve. In no instance shall there be discrimination against Indians or schools enrolling such Indians, and as applicable, the rules and regulations pertaining to student rights and due process (25 CFr Part 35) be observed.

E. No contract funds under the Johnson-0'Malley Act shall be made avallable by the Bureau directly to other than tribal organizations, atates, school districts, and Indian corporations. However, tribal organizations, states, school districts, and Indian corporations recelving funds under this part may use the funds to subcontract for necessary services with any appropriate individual, organization or corporation.

F. The Bureau of Indian Affairs may provide additional guidelinea to the State Board of Education on the diatribution of contract funds based upon the special cultural, linguistic, social, educational needs of the communities involved, Including the actual cost of delivering educational services, or by such other factors consistent with aurhorit 1es granted thereto.

G. Records shall be maintained on financial transactions involving the receipt and expenditure of funds provided under the contract in a manner which will provide accurate, current and complete disclosure of financial status, correlation with budget or alloweble cost schedules, and clear audit facilitating daca.

H. During the term of any program created under this Plan and for three years after the program or undertaking is completed, the Comptroller General and the Secretary, or any of their duly author1zed representatives, shall have access, for audit and examination purposes, to any of the contractor's books, documents, papers, and records which, in their opinion, any be related or pertinent to the contract or any subcontract.

I. All contracts, non-confidential records concerning all tudents served by the program, reports, budgets, budget estimates, plans, and other documents pertaining to preceding and current year admlaistration of the contract program shall be made avallable by the contractor and local school of ficlals to each merer of the Indian Education Comittee and to members of the public upon request. The Department of Education, Division of Indien Education, or local school of ficlal shall provide, free of charge, angle copies of such documents upon request. 
J. In those states where Public Law 83-280, 18 U.S.C. 1162 and 28 U.S.C. 1360 do not confer civil jurisdiction, state employees may be permitted to enter upon Indian lands, reservations, or allotments if the duly-constituted governing body of the tribe adopts a resolution of consent for the following purposes:

a. Inspecting school conditions in the public schools located on Indian tribal lands, reservations, or allotments.

b. Enforcing state compulsory school attendance laws againgt Indlan children, parents, or persons standing in loco parentis.

K. All prograng established under this Plan ast comply with the applicable requ1rements in the Federal Procurement Regulations (41 CFR Part 1), as supplemented by the Interlor Procurement Regulations (41 CPR Part 14), the Bureau of Indian Affairs Procurement Regulations (41 CFR Part 14H), except 41 CFR Part 14H-70, Subpart D of 43 CFR Part 2 which implements the Privacy Act (5 U.S.C. 552a), and such other procedures determined by the contract officers' representatives (ADE/77/2CLT).

\section{ARIZONA LNDLAN EDUCATION ASSOCIATION}

A. The statewide Arizona Johnson-0'Malley Indian Education Comittee hereinafter knom as the Arizona Indian Education Association shall be composed of one member and one altemate as nominated or selected by procedures determined by each Arizona Indian tribe or tribal government.

B. Each local Indian Education Comittee (s) establighed under this Plan, except Intergovernmental Agreement 8 , may elect one representative and one alternate from its members to participate in the activities of the Association.

C. For purposes of this Plan, the Arizona Indian Education Association shall serve in the liaison capacity to the Arizona state Board of Education. Departwent of Education, and the Bureau of Indian Affairs and may serve and operate under the terms and conditions delineated in the constitution and bylaws pursuant to P.L.93-638.

D. Additional functions and responsibilities of the Association may at its option be exercised, provided, that auch are in accordance with the applicable state, federal, and local laws or regulations, and the provisions of this Plan for educational purposes.

E. The Arlzona State Board of Education may in the performance of its duties designate the Association to undertake special activities for the benefit of Indian children, Indian communities, and public school districts.

F. The Arizona Indian Education Association in connection witl, the Arizona Department of Education ay provide assistance through an Indian tribe, to provide per diem and mileage for tribal representatives or alternates. Representatives from each Indian Education Commitce shall be relmbursed from $1 \mathrm{tg}$ approved budget to attend and vote at Arizona Indian Education Association meetings as designated in the constitution and bylaws of the Arizona Indian Education Assuciation.

G. The Arizona Indian Education Association ay conduct conference(B) and workshops on Indian Education in cooperation with the Phoen1x Area office and the Arizona Department of Education, Division of Indian Education. Funds for this purpose shall be provided pursuant to Special Services. 
APPENDIX D

Tribal Education Plan

1979 


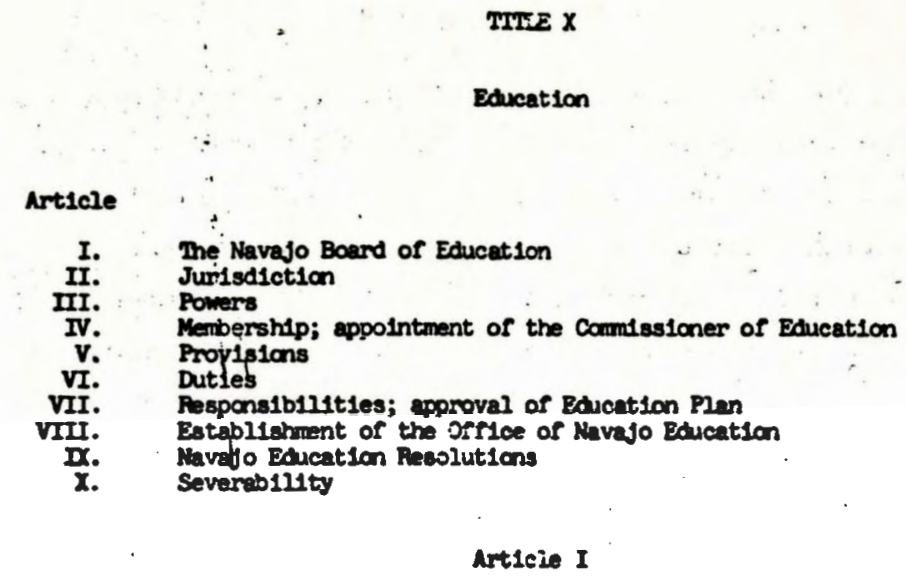

Artieie I

- Sac. 1.0 Eataplishment of the iavelo 3oard of Sdicetion

There is establiahed a Navajo Board of Jesustion, herearter called the Boerd, for the purpose of approving pollcy consestant wth the Navio Cont-

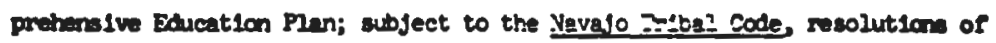
the Navajo Tribal Counc11, Sederel laws, and such state lew and regulations rade applicuble by the Nevejs Tribel Corscil, by iessiutions of the Navio Imibel councll enacted afte the date of approvel of this resolution, or by Inil decrees of ny foderai or Mribel court.

\section{Article II}

Soc. 1.0 Jumisdiction

The Board shall have Jur1sdsetion over the systers of acucation and" perwannel engagad in ducatianal servicss erfecting the Havajo Nation and aurzout

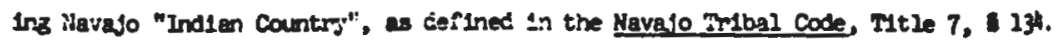

Article III

Sec. 1.0 Bowers

Sec. 1.1: The goard shall tave the postar to nepotiate with atate cutional ancies, the Bureau of Incien Arruir's schools, wission and priachools; and other woncles and orgenizations directly or indirectly arrecting injo duction:

Sec. 1.2: to recumend and propose logdsletiton repending Vlavajo Auntional metters;

Sec. 1.3: control, manage eis direct ell colucational Institutions, mopt as otherwise provlded by 2ma;

sec. 1.4: promulgete, publish, and enfares reguletion to axercise It. euthority cranted purreusent to this Posolution;

Sec. 1.5: eply to the Naviso Tribal court, or wo count adth conpunt Jurlediction, for en infunction, irit of mendars or other apropelate nilief to enforce the provisions of this \$solution. 
Articie IJ

Soc. 1.0 Membership

8ec. 1.1: The Board shall bave an elected zembership with the following qualifications:

(a) Candidate mist reside intidn the Ageray Jurlsdiction;

(b) must have attained legel voting age;

(c) must have a degree and/or adninistrative experience in on educational rleld;

(d) shall not be a member of the Navajo Tribal council; except as provided for the cheirman of the sducation comnittee;

(e) upon election, shall not be employed ill-time, part-time, or be a consultant to tise orrice of Essucation;

(f) If menber is elected to tive Navajo Trical Counc1l, menber wul be terrinated from the Joars.

Sec. 2.0 Elections

The ilavajo soerd of Electle.s Supervisors shall t:ithin elxty days of the pessaze of th1s Pesslution, concis: certifled elections of one representative for each twenty thousand people :sr major (rastion thereor) reolding in each agercy.

Sec. 3.0 iensth of Serrice

Sec. 3.1: The term of servise shall be four years

Sec, 3.2: In onder to matnsatn the continusty of the Boand, the explration of terts of Boenc members he:- be atagsered $s 0$ that the tern of one-hale of the poand will expire every =wo years.

Sec. 3.3: At the Intial resting of the Board, the members shall detemine anong themselves by lot inich. -embers' tem siall expire in two years and four years.

Sec. 3.4: The lenptr. of ser.1ce for eesi sected menter of the Board shall be ifnited to two consecutive ters.

Sec. 4.0 Other Menbers :Hth Full Vot:rz Ponens

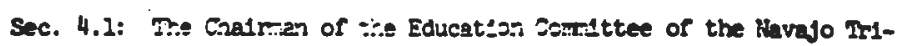
bel Councll shall serve es an ex-orficte re-ber of tise 3oard.

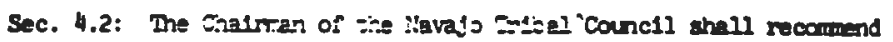
two ar more persons, ane of stominill be aspointed by tise elected Board.

Sec. 4.3: The Chalman of ise Navajo irtbal Council shall appoint a currently surolled student attending a ssisol under the jurisdiction of the Board. The selection of the student will be sus:ect to the following:

(a) recounentations recelvis Iran a high school or inatitution of higher eiucation.

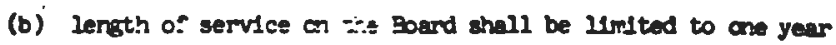


Sec. 5.0 The Conitsaloner of the office of Navalo Edusation

Sec. 5.1: The menbers of the soard shall apolint the combastaner of the arfice of ilavajo Education. The eppointant of the corndsatoner will be subject to the sollaring conditians:

(a) eppointee must meet qualimeations deternined by the Bond;

(b) must be an enrolled manber of the lavajo Iribe;

(o) must have the concurrence of the Navajo Fribal counc1l;

Sec. 5.2: The comnlasioner shall be a non-voting maber of the

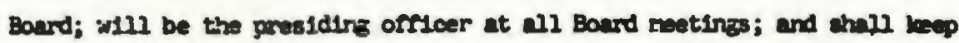
recondis of all meetings.

Sec. 5.3: The Board shall delegate ard autho-1ze such durties and

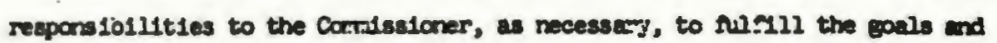
objectives of the education policy(1es) of the Havejo Matison.

Sec. 6.0 Boend orrycers

Sec. 6.1: The Cormissioner ahall seres at tise prealding artloer and i Presldent of the Baard at all Board meetings.

Sec. 6.2: At the f1ret rogilar meot'ses of the Board, the nuber shell

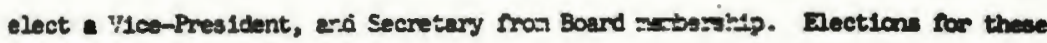

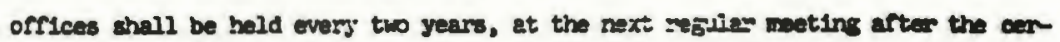
tirled elections.

Sec. 6.3: In the ebsence of the Presicent, tive Vico-Preeldent, inell preside at Board meetines.

Sec. 6.4: Regular meetinz of the Board thall be held wery six

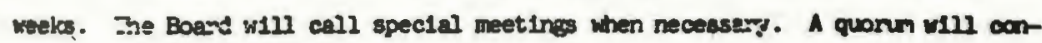
sist of f simple majarity of Board menbers.

Article $v$

\section{Sac. 2.0 Caneral Provisions}

sac. 1.2: The Board ahall adopt adninistrative rules and roguletion for Its internal operations, and s.111 subnit arnuel and apeciel bubot requeste for riview and eppropriation by the kavajo Tribel councll.

Sec. 2.0 Renivel mon orras

- Sec. i2.2: Upon conviction of a relons, wn nexber shall coaso to hold arrice.

Saci 2.2: Nenbere not attendins regular and spectul Bond neating wth edequate notice of such meetings, on three consecutiv oocenions, andi contititute naziect of duty, subject to smovel ty the soand.

Sac. 2.3: Elected menters of the Bourd thall be aibjoct to removal Imm the Board by a recell voted by the's enstituer.sy, sibject to procotures coverned toy the Mavajo Board of Elecilors Singervess. 
sac. 3.0. Indemifleation of Bcand Yebers.

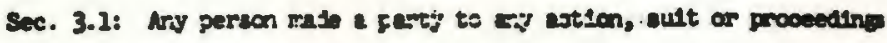
by resean of the feot that $\mathrm{b}$, his testates ar lintestete, is or was a wenber of

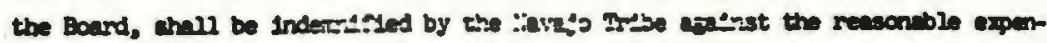

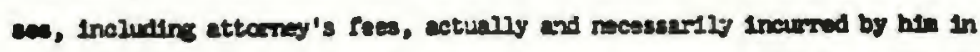
comection with the defense of such ection, suit or procesdins, or in comection with ws appeal therein, except in relation to matters as to which It whall be

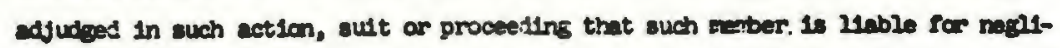
ence or miscandiset in the performance of his duties

$$
\text { Article v? }
$$

\section{Sec. 1.0 Duties}

Sec. 1.1: The Soand shall srogerly and unimarly enforce the provtelons of the Mavajo Education Pollcy:

Soc. 1.2: Determine polley Sor the orrice of Namjo soveation;

Soc. 1.3: ppoint the Conniseloner of the arrice ar Mavajo Bducetion, with the cossent of the Navajo Iribel Counc1l;

Soc. 1.4: approve courses for instruction, requiremants for oreduation and atandards for all schools abiect to the Jurisdiction of the Bourd; Sec. 1.5: require price approval for any educational progrem whlch Is to be conducted, spansored, carried on, or caused to be arrried on by any other agency or organisation;

Sec. 1.6: euthorive educational progrems to be canducted in schools, and promilgate and publish regulations governing wl such educational progrems;

Sec. 1.7: assess and evaluese all schools within the jurfadiction of the Eoard for :ievalo aceseditation;

Sec. 1.8: deternine the quelimations for and 1save a tenching cer Nonte to iny person teaching, assiating teachers, susevising in inutructional

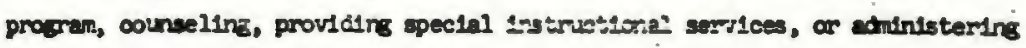
In schools subject to the jurissietion o: the soars;

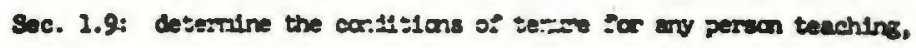

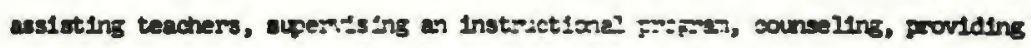
epectel instructional cervises, or adninistering in szizols subject to the jurisdiotion of the Boord;

Sec. 1.10: after a hearing, suspend or revoice a certirleate lsoved to ary person teaching, assisting teachers, supervising an instructianal praprean, courseling; proriding apecial Instructicnel cervices, or adnintstering in schools oubject to the ju-1sdiction of the Boars, upon conviction of a relary or misdeanore irwolvins noral terpitude or gress incorgentance or neglect of duty;

Sec. 1.21: set guldelines to Insure for competant adninfstration of all schosls subject to the Jurlsolction s: the Boand; 
Sec. 1.12: complle periolic reports an presiribed forre man all schools sibject to the Jurisdiction of whe Sca-1, in scoordance with the atendands of certification and accreditatior:;

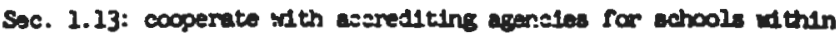
the jurisdiction of the Boand;

Sec. 1.14: plan and eppli throuth the Nava's Iribal council, far

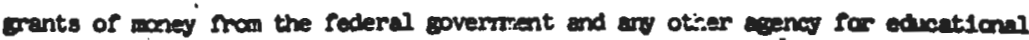
purposes and expend the money for the pupposes apeciried in the crant;

Soc. 1.15: reviev: and recomind for aprovel by the Esucation Committee of the ilatajo Iribel Councll, by-lari3 for solerrise boands of colleges, vocutional centers, acadentes and other edicational 1nstitutions, ancies and

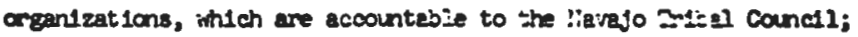

Sec. 1.16: review decistons and zeire rec=-ondations to the povern-

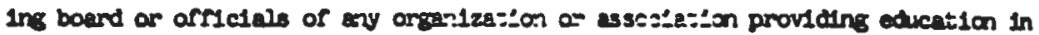
schools subject to the jurisiletion of tive sosw;

sec. 1.17:' assess and evglue:s fC= B:crest:s=10n purposes at lenst

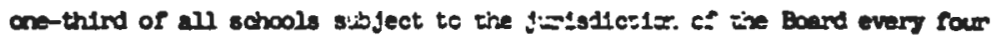

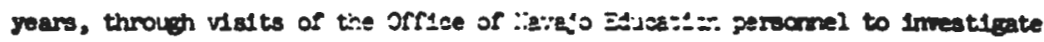

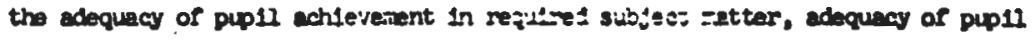
ectivities, Inetianal feasibility of schosl argenizetion, dequacy of atarr preparation and other matters bearing upon the etucetion s: atudents

soc. 1.18: provlde for manegenent and other nocessary perconnel to educational institutions serring Havajo pexcle, which are in need of assistance, uritil surh tire tinat the operation has ret the provis:zis of the pollcy, its standarta and rezllations;

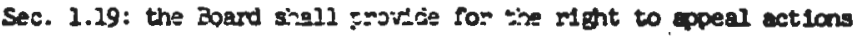
towen by locul school boends, subjest to the jurledistion of the Board, in accordence with procedures contgined in ipoendix. of the solicy;

Sec. 1.20: upan request by a perty to the 11spute, the Band ay arbitrete disputes relating to oducesional watters within its JuriediotIon, with the powar to subpoen witnesses, Information and testimary; and woy enlist the, ald of impartial coups osteide the eqhere of interent or Inval vement; ".

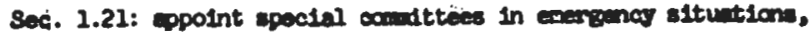

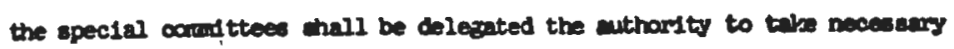
weasures on axch twergency issues or insidents affecting the eduation of

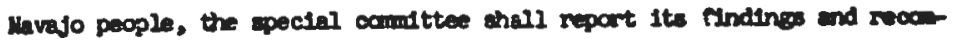
wendations to the poard for action;

Sec. 1.22: set minimm outdelines for $200 \mathrm{ll}$ school board opere-

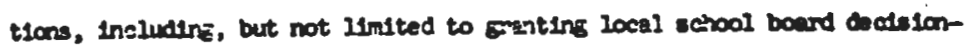
malng porters in selection of atarf, capensetion c: ssiool bourd nerbers, sicilities use and dispute settlerent; 
Sec. 1.23: cooperate with tice states $0: 2 x-20039$, New Mexd $\infty$, and Utah, in presenting the needs of Navajc sducatio. 2n ters of population dstribution, both geographic end age, sctsol enrolleest, income, and allocation of state school rinds;

Sec. 1.24: matntain affilla:1on with plansing council representative of communities, agencies and organtzations involved in Navajo Education. The Board shall seek advice from the pleming councils in pollcy develogment and ruture planning;

Sec. 1.25: require a fractua repat tran eech school by Augut 1 , of each year which Indicates what effes: the ourrent fuding rormula and other rinancla' alds have had an adicational jrogren cperations and student proxeas. and wat changes, if eny, are needed;

Sec. 2.26: the Soand shall sivluate reparts, consolidnte Nindings and present a lavajo educational repor: so the legtslet i ve eesion of the limujo Tribsi Counc1l on an amual basis;

Sec. 1.27: In Goneral, to do all and everythinf, elther with or wlthout the Navajo Mation, necossary to convenlent, to the scconpliahment of aw of the purposes herein stated; and in general to do and and all things and exerclse ary and all powers, rights and privileges which a Boand of Edweation may now or hereafter be organlaed to do or to exerelse.

\section{Article VII}

\section{Sec. 1.0 Responstbilit1es}

The Boand wII imnediate $2 y$ drect the completion of the lavajo Copprehensive Ecideation Plen regarding elucationel plaming for the Havajo Nation. The Boerd, with the Comissioner ans the antece of Navajo Education will develop ti: followins edication plens:

Sec. 1.1: Early Cillahos Esicet:or: Jlen, establish pre-school pro-

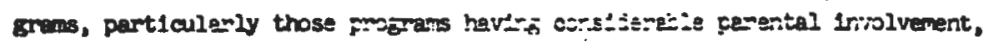

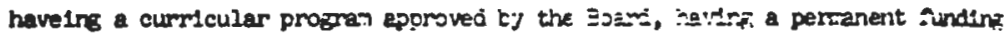
source, and are provided tesindcej ess15zence in enses st grogran developtent and operations;

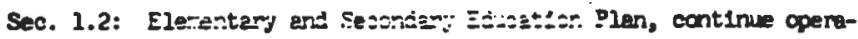
tion of kindercerten throus: twelfh Frate ecjes:1s:2i systens for youth; also, Improve and expand the eaisational opoorifunties provided for Navijo students claser to their homes;

Sec. 1.3: Past-Secontarj Ecisestion Plan, continue operation of

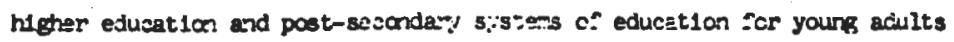
and adises, utijizing Institutions orth sn asd of: the reservation.

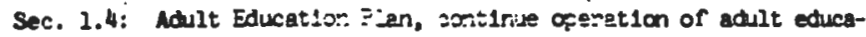
tion systens; also, 1mprove and expajs trs edicacional ofcortunities orovided by these eysterz; 
Sec. 1.5: Vocational Ecucation PIn, continue operation, Ipproveent aps expansion of vocational education programs for young adults and acults, utllizirg intitution both an and off the reservetion;

Sac. 1.6: Coumunity Schoole Plan, cont Inve cporetion, Ipprovenent and expansion of locel comanity schools, includine corminty-controlied achools for Mavajo children, youth, and adults;

Sec. 1.7: Spectal Education PIm, continue cperetion, inprovement and expension of meciel education for itavajo children, youth, and acults; apectal cheation prozrens wlll be given priority for establisiment in local comensties;

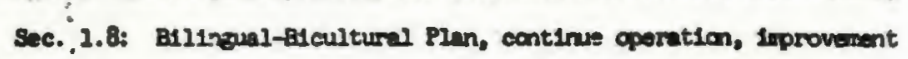
and expersion of bilingul-bloultural education prozress at all levels of ecucation for children, youth, and adults in institutlors serrers lavajo on and off the meervation;

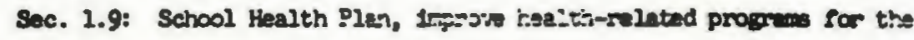
benellt of Navajo enlldren, youth, eré adults;

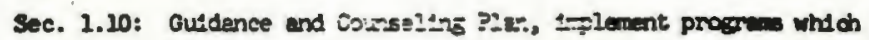

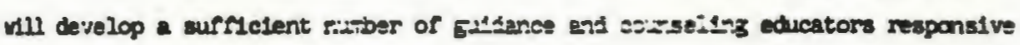

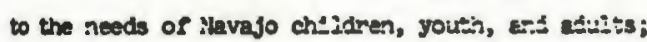

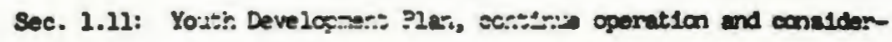
wle oxpansion of year aroind youth dereloprant prezesta that are responsive to the needs of Navajo ohtidre: and youth, Inclubing recreation program and sumer employment;

Sec. 1.12: Post Greduate ard Brofesalonal Development PIn, Plen and

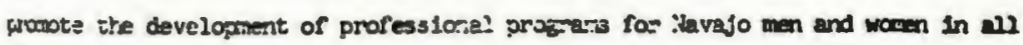
resomized disclplines of higher educat:m;

Sec. 1.13: Vocut1enal Reinillitesion Iier, secure and coordinate RndIng ani in cooperation with local, stets, anj rederal ezencies, arganive and implemr:t a corpretiensive progrem trat rell grovide treintrs, counseling survices, and employment for physically and mentaliy hendicapped Navajo.ch1ldren, youth, and adurte;

Sec. 1.14: Aiternatives in Stusation Plen, support development of alternative forms of edioation for ilava'ss, and provide technical assintunce to persons and organizations inveutigatins or-eatablishing alternative proenwa and schoals;

Sec. 1.15: Educational Startands P1n, cocperate with ecorvolting

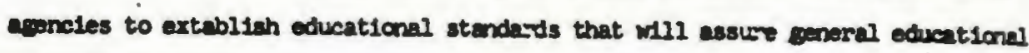
quartity and equivalence;

Sac. 1.16: Research and Dovelogment Center Plan, coerete a Mavajo Bduentionel Research and Developpent Cerser and Lubrurs', to provide a centroulled resource center for rescarch und ceveloges: of efueuticnal prograns; also, the

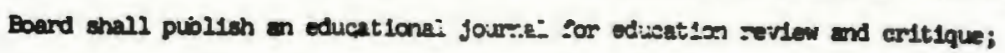

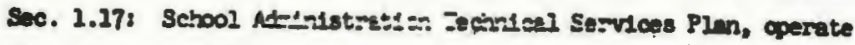

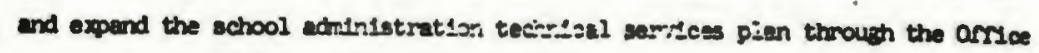
or Navajo Edwention; 
Sec. 1.18: Educat1ari? Jac4-120es Eler, deveiop in educational

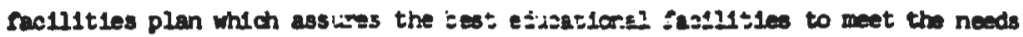
of school comanfties, inclioing loeal e:d rezoneliy besed institutions;

Sec. 1.19: Edication Ziofessloss Develsonent PIen, operate, Irprove, and expand the Navajo Education Professiens Develogment Progrem to meet the needs of education for liavajo people on and ors the reservation; .

Sec. 1.20: General Services Slen, services, such as, educationel

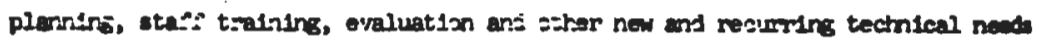
of schools and collezes, $M 11$ be cxovids:, s= essistance, if necessary, for de-

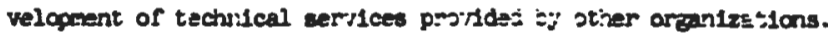

\section{Sac. 2.) Aporoval of Educational Plans}

Sec. 2.1: The Orflce of Navejo Education ahall prepare necessary socuments and other pertinent materials releting to the plen for the Board ror sovies and modirication;

Sec. 2.2: The Board will submit the plan to the Bducation comitteo of the :avajo iribel council for review and modirication;

Sec. 2.3: The Board shall then approve the plen for publication to the general publiq;

Sec. 2.4: The Board thall then rake public notice meekly in newepapers and other lmedie for three cansecutive weeks, that the plan is eveilable for inssection.

(a) Hot1ces must name locat10ns througingit the Navajo Reservation and other sites where tize plen is avetiable;

(b) Hotices shall detall the app:sprists grosedures for vubutesion or recomendations and nodin_ss:1sis to the plan.

Sec. 2.5: Upon determinaticn of she Esams a public request, public beurings may be held regarding the educB:10. plas.

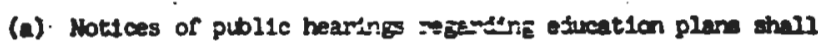
inciude the tine, date, and loce:ion $a^{\circ}$ each hearing.

(b) Notices sinell be made tiroust rad10, television and newopapers, mekkly, for a perlod of three cansecutive weeks pr-jor to the hooring date set by the Boord.

- (c) Notice shall include procedures coverning participation in the hegminos and appropriate gicdelines for submission of recomendations and modiricatinz.

Sec. 2.6: The Board shall allo: Et least thirty days arter the conpletlon o: the hearinzs for written public consents, and arter ouch tire, thall revile: anj consider all input and make any necessary modimcations and reasons 
therefore, to the plan.

Sec. 2.7: The Education Cerrittse of the :ivajo Tribal counc1l chall approve and Inocrporate the plan es gert of the ilevajo Comprebenalve Education Pien.

\section{Artieis VIT}

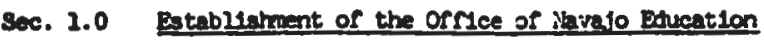

The Board and the Conmisalorer sull eet forth the cperational pollc1es and procedure of the ortice of Minjo isucation. The Mavajo Darision of polucation andll become the orrice of Nerno Ifucation, ell runctions of the orricers and the arryo shall be under :ise divection of the Coumlsatonar of

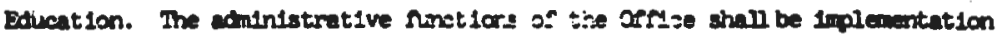

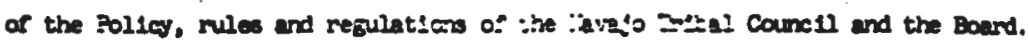
Sec. 2.0 Duties

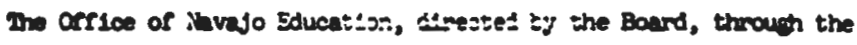

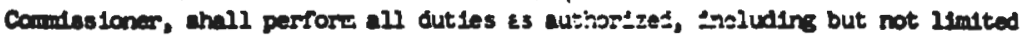
to the folloring:

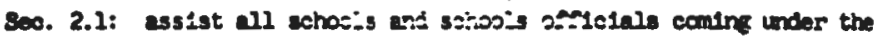
Juriediction of the Board;

sec. 2.2: dvise governins soards ard gecialals of educationar Institutione cperating witinin the Juristiction of tise 3oard concernitis the Polley;

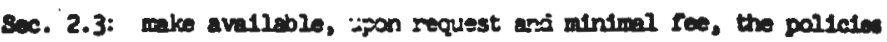
plana, rules, and requlettons promulgats by the Boend to locel school boards . and ary Interested perwons;

Sec. 2.4: ocininister and c:ssds-ate surds allocated for esticational prozeras;

Soc. 2.5: render tecinica: ssistence to ilallilied comanity arzan-

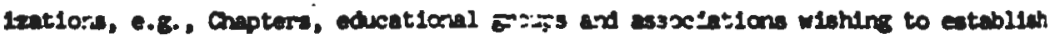

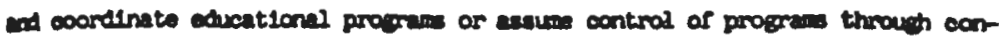

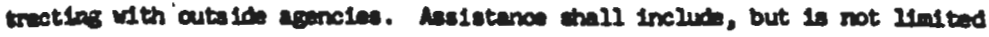

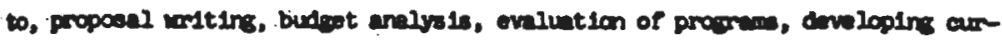

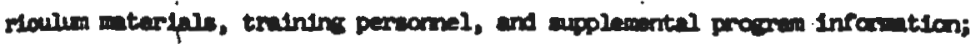

Soc. 2.6: arrial215, prepare and publish a report on the overell conieverents of the cojectives and poels of the pollay to the Boend;

800. 2.7: keep accurtite reoords of all wonies, reports and eveluttion recelvid ty the Orrice of lango Bducation and the Boord;

Sec: 2.8: confer with local whool bounds and certified sahool

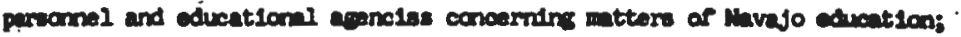

sec. 2.9: cotively participate in all escentin relationahips

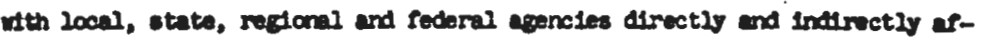
roting thevjo coucation. 


\section{Sec. 3.0 Personnel}

The Boand and the Comissioner are authorlzed and directed to proNow aystem for the appointment and tenure of perexmel in the orrios of

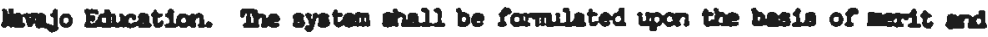

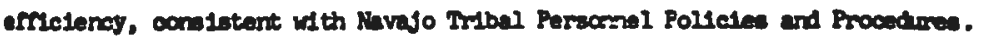
sec. 4.0 Musto Preference

The hiving, tretinis and promotion of perwarnel in coplinge with Havajo preference anall be etrictly enforoed. Provided, hovever, thet if are enent or contract requires coupliance with Indian preference provlalons of 25 U.S.C., or other redervi leglelation, than the Board obell comply with auch lecelelation.

200. 5.0 Staff Develooment

The Boerd and the Coundesioner will oonduct starf develogment proorian for the Orrice of Nerwjo Education persarnel as outlined in Appendix of this palley.

Artele D

Soc. 2.0 Herajo Education Resolutions

All rosolution of the Navajs Mibel council not consistent with

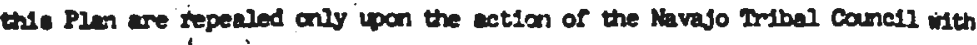
roiend to each 'resolution so arrected.

sec. 1.0 Severeb111ty

Artsele $X$

If pry ection of application of eny ection of the llavjo compohenatve Education Poliay is held Irvalid, the remainder, or Its appliation to other situntiasilor persons, shall not be erfected. 
APPENDIX E

Methodology 
This study depends on two main sources of information for population and detailed characteristics of the Navajo tribe; the Bureau of Indian Affairs and the United States Census. Reliance on these two sources requires an investigation into how each agency collects data in order to evaluate its reliability and limitations.

Data were collected for 1970 from the Bureau of the Census, Subject Report, the American Indians, August, 1973. The count used for the Navajo population and other statistics was the reservation figures for the area delineated in Figure 1 of the text. It is important to note that the population in residence on the reservation is not representative of the Navajo tribe as a wholle. For this research, the actual count of the entire Navajo tribe throughout the United States was not necessary. The focus of the study was the improvement of social conditions under the self-determination legislation. Thus, the Navajo reservation was chosen as representative of any changes since the relative isolation of the Navajo land is assumed to be typical of the social conditions experienced by the American Indians in general.

Data from the 1980 Census are not yet available in subject report form. For the writing of this report, the information available is noted in Tables XII - XVI in the text. Because the Navajo reservation encompasses three states (Arizona, New Mexico and Utah), the social and economic statistics are delayed until the state 
information is released and can be aggregated in a different format for the reservation. Current information indicates that the statistics will not be available until August, 1983. Since this information is not available from any other source, including the Navajo Nation, profile data could not be compiled for certain indicators in 1980 . The other source of information for this project, the Bureau of Indian Affairs, is used primarily to collect data on the educational indicators for the decade, 19701980. Organized in 1824 as a part of the War Department, its early functions were to carry out treaty negotiations and regulate trade with the Indian tribes and growing number of white settlers. However, in recent years with its transfer to the Department of the Interior, the BIA now has the assigned task of administering Indian affairs in general. Nearly all the reports on tribes under Federal jurisdiction emanate from the BIA. Data used for this research came from the Navajo Divison of Education, Window Rock, Arizona and from an annual report published by the BIA entitled, Statistics Concerning Indian Education. The data from the Navajo Division of Education is submitted to the BIA which coordinates the information for publication. In order to increase comparability, the additional rears of 1972 and 1977 were included. Other years within the decade could not be used as the reports for those years were often incomplete. It should also be noted that no educational statistics are 
available for 1980 from the Bureau of Indian Affairs due to a lack of funding support to collect and publish the information.

Final remarks concerning these sources refer to the reliability and accuracy of the information presented in this project. The Bureau of the Census is a more independent body and the information on Indian tribes is judged to be less biased than the data from the Bureau of Indian Affairs. The BIA is often criticized for its reports by. many Indian tribes because it is not an independent body but an administrative agency which is given authority to administer Indian Affairs. The BIA is frequently reporting statistics which reflect its own performance rating in efficiently providing Indians with the opportunities guaranteed to other citizens of the United States. Although this bias is recognized, the statistics are used in this project as they represent the only source of information on the social process of education. 
Johnston, Denis. An Analysis of Sources of Information on the Population of the Navajo. Washington D.C.: Government Printing office, 1966.

Kelly, Lawrence. Navajo Indians and Federal Indian Policy: 1900-1935. Tuscon: University of Arizona Press, 1968.

Leacock, Eleanor, and Lurie, Nancy. North American Indians in Historical Perspective. New York: Randon House, 1971.

Land, Kenneth, and Spilerman, Seymour, eds. Social Indicator Models. New York: Sage Foundation, $1 \overline{975 .}$

Shepardson, Mary. Navajo Ways in Government: A Study in Political Process. New York: American Anthropological Society, 1963.

Terrell, John Upton. The Navajo. New York: Weybright and Talley, 1970.

U.S. Congress. House. Committee on Education and Labor. Oversight Hearings on Indian Education before a subcommitte on Elementary, Secondary and Vocational Education, 96th Congress, 2nd session, 1980

U.S. Commission on Civil Rights. Report on the Navajo Nation: An American Colony. Washington, D.C.: Government Printing Office, 1975.

U.S. Department of Commerce. Bureau of the Census. United States Census of Population: 1970. Subject Report, American Indians

U.S. Department of Commerce. Bureau of the Census. United States Census of Population:1980. General Population Characteristics, Navajo Reservation. PC80 1-B33, 1982.

U.S. Department of Interior. Bureau of Indian Affairs, office of Education Programs. Statistics Concerning Indian Education, Fiscal Years 1970, 1972, 1977 and 1979.

U.S. Department of Interior. Bureau of Indian Affairs. Report of the National American Indian Court Association on Long Range Planning. Washington, D.C.: Government Printing office, 1978 


\section{Legal references:}

1868 Treaty between the United States of American and the Navajo Tribe of Indians, concluded June $1,1868$. Statutes at Large, vol. 15 (1868).

1830 Indian Removal Act of 1830. Statutes at Large, vol.4 (1830).

1887 Dawes Severalty Act. Statutes at Large, vol. 24, current version at U.S. Code, vol. 25. (1976).

1934 Indian Reorganization Act. Statutes at Iarge, vol.48, current version at U.S. Code, vol. 25 (1976).

1934 Johnson-0'Malley Act. Statutes at Large, vol. 48, current version at U.S. Code, vol. 25 (1976).

1950 Public Law 83-280. Statutes at Large, vol. 67, current version at U.S. Code, vol. 25 (1976).

1950 Public Law 874. U.S. Code, vol 20 (1950).

1950 Public Law 815. U.S. Code, vol. 20 (1950).

1968 Civil Rights Act. U.S. Code, vol. 25 (1970).

1970 Nixon's Message to Congress on Indian Affairs. Public Papers of the President at vol. 565 (1970).

1972 Indian Education Act. U.S. Code, vol. 20 (1976).

1975 Indian Self-Determination and Education Assistance Act. U.S. Code, vol 20 (1976).

1978 Public Law 95-471. U.S. Code, vol. 25 (1978)

1978 Edcation Amendments of 1978, U.S. Code, vol. 25 (1978). 